\title{
Articles
}

\section{The Rise of Dispersed Ownership: \\ The Roles of Law and the State in the \\ Separation of Ownership and Control}

\author{
John C. Coffee, Jr. ${ }^{\dagger}$
}

\section{CONTENTS}

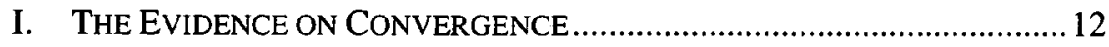

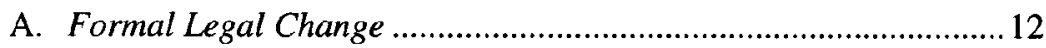

B. The Structure of Share Ownership ............................................. 15

C. The Growth of European Stock Markets .....................................16

D. The Emergence of an International Market for

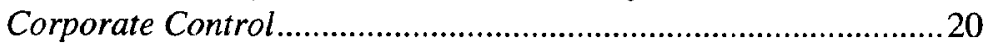

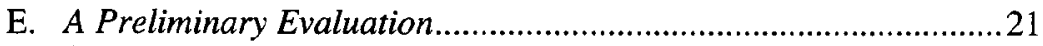

F. The Status of the Insider-Dominated Firm.....................................23

II. WHEN DOES SEPARATION OF OWNERSHIP AND CONTROL ARISE?

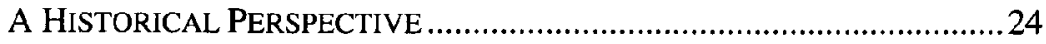

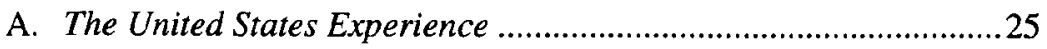

1. The Role of Investment Bankers ..........................................26

2. The New York Stock Exchange as Guardian of the Public Investor......................................................................34

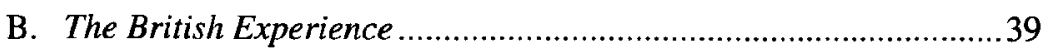

$\dagger$ Adolf A. Berle Professor of Law, Columbia University Law School. The author is grateful for helpful comments from Brian Cheffins, John Langbein, Roberta Romano, and Andrei Schleifer; from my colleagues, Ronald Gilson, Victor Goldberg, Jeffrey Gordon, and Curtis Milhaupt; from William B. Williams, Esq., of the New York Bar; and from participants at the Yale Law School Raben Lecture. 
C. A Civil-Law Contrast: The French Experience .45

D. The German Experience: Statist Intervention That Stunted the Market 51

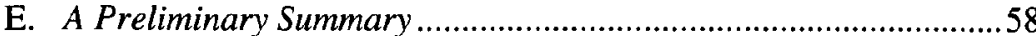

III. “DOES LAW MATTER?” RECONSIDERED ………………………..........59

A. Law and the Decentralized Common-Law World .........................59

B. The Sequence of Legal Change: Reinterpreting LLS\&V................64

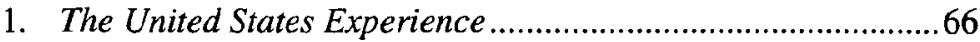

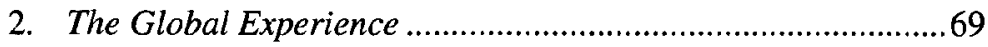

C. The Political Theory of Dispersed Ownership .............................71

D. Implications for Transitional Economies ......................................76

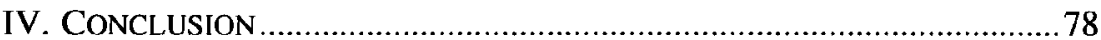


Recent scholarship on comparative corporate governance has produced a puzzle. While Berle and Means had assumed that all large public corporations would mature to an end-stage capital structure characterized by the separation of ownership and control,' the contemporary empirical evidence is decidedly to the contrary. Instead of convergence toward a single capital structure, the twentieth century saw the polarization of corporate structure between two rival systems of corporate governance:

(1) A Dispersed Ownership System, characterized by strong securities markets, rigorous disclosure standards, and high market transparency, in which the market for corporate control constitutes the ultimate disciplinary mechanism; and

(2) A Concentrated Ownership System, characterized by controlling blockholders, weak securities markets, high private benefits of control, and low disclosure and market transparency standards, with only a modest role played by the market for corporate control, but with a possible substitutionary monitoring role played by large banks. ${ }^{2}$

An initial puzzle is whether such a dichotomy can persist in an increasingly competitive global capital market. Arguably, as markets globalize and corporations having very different governance systems are compelled to compete head to head (in product, labor, and capital markets), a Darwinian struggle becomes likely, out of which, in theory, the most efficient form should emerge dominant. Indeed, some have predicted that such a competition implies an "end to history" for corporate law. ${ }^{3}$ A rival and newer position-hereinafter called the "Path Dependency Thesis"postulates instead that institutions evolve along path-dependent trajectories, which are heavily shaped by initial starting points and pre-existing

1. Adolf A. Berle, Jr. \& Gardiner C. Means, The Modern Corporation and PRIVATE PROPERTY 5-19 (1932).

2. The seminal work of La Porta, Lopez-de-Silanes, Shleifer, and Vishny (LLS\&V) has established the existence of these rival systems, that they seem to have evolved along distinctive legal trajectories, and that they correlate with significant differences in the legal protections provided to minority shareholders. Rafael La Porta et al., Corporate Ownership Around the World, 54 J. Fin. 471 (1999). More recent work in the same vein has shown that the private benefits of control appear to be much higher in French civil-law countries than in common-law or Scandinavian countries. Tatiana NENOVA, The Value of CORPORate VOtES and CONTROL BENEFITS: A CROSS-COUNTRY ANALYSIS (SSRN Elec. Library, Working Paper No. 237,809, 2000), available at $\mathrm{http}: / /$ papers.ssm.com/paper.taf?abstract_id=237809.

3. For representative statements of this position, see FRANK H. EASTERBROOK \& DANIEL R. FISCHEL, THE ECONOMIC STRUCTURE OF CORPORATE LAW 4-15 (1991); and Henry Hansmann \& Reinier Kraakman, The End of History for Corporate Law, 89 GEO. L.J. 439 (2001). 
conditions. ${ }^{4}$ In short, history matters, because it constrains the way in which institutions can change, and efficiency does not necessarily triumph.

These two rival positions do not, however, state the deeper puzzle. That puzzle involves the origins of dispersed ownership. The recent provocative scholarship of La Porta, Lopez-de-Silanes, Shleifer, and Vishny (LLS\&V) has not only shown the existence of two fundamentally different systems of corporate governance, but has placed legal variables at center stage in explaining the persistence of these two systems. ${ }^{5}$ LLS\&V have boldly argued that civil-law legal systems provide inadequate protections to minority shareholders, and hence dispersed ownership can arise only in a common-law legal environment. To support this conclusion, they assembled a worldwide database that shows that the depth and liquidity of equity markets around the world correlate closely with particular families of legal systems, with common-law systems consistently outperforming civillaw systems. ${ }^{6}$

4. Lucian Arye Bebchuk \& Mark J. Roe, A Theory of Path Dependence in Corporate Ownership and Governance, 52 STAN. L. REV. 127 (1999); Amir N. Licht, The Mother of All Path Dependencies: Toward a Cross-Cultural Theory of Corporate Governance Systems, 26 DEL. J. CORP. L. 147 (2001).

5. Rafael La Porta et al., Law and Finance, 106 J. POL. ECON. 1113 (1998) [hereinafter Rafael La Porta et al., Law and Finance]; Rafael La Porta et al., Legal Determinants of External Finance, 52 J. FIN. 1131 (1997). For the latest and fullest statement of their position, see Rafael La Porta et al., Investor Protection and Corporate Governance (2000) (unpublished manuscript, on file with author). See also NENOVA, supra note 2 (finding significant disparities in the private benefits of control enjoyed by controlling shareholders depending upon the country of incorporation and the legal family to which that jurisdiction of incorporation belongs).

6. LLS\&V initially conducted an inventory of the laws governing investor protection in fortynine countries. Focusing on the corporate law and bankruptcy law of these countries, they next constructed measures of shareholder rights (for example, the presence or absence of "one share, one vote" rules, the existence of remedies available to minority shareholders, and the possibility of proxy voting by mail as opposed to voting in person) and measures of creditor rights (for example, whether creditors are paid first in liquidation, whether managers can unilaterally seek judicial protection from creditors, etc.). Rafael La Porta et al., Law and Finance, supra note 5. These measures were then combined with measures of the quality of law enforcement in each jurisdiction to create an unprecedented data set quantifying differences in legal rules, and in rule enforcement, around the world. Although they found large differences in the prevailing rulcs and established that these differences could be grouped into four major legal families-common law, French, German, and Scandinavian civil law-doubt has persisted among legal scholars as to the meaningfulness of the differences observed. Basically, the LLS\&V index focuses on six legal variables: (1) proxy voting by mail; (2) the absence of any requirement that shareholders deposit their shares prior to the general shareholders' meeting in order to vote them; (3) cumulative voting; (4) the ability of shareholders to sue their directors or otherwise challenge in court the decisions reached at shareholder meetings; (5) the ability of ten percent or less of the shareholders to call an extraordinary shareholders' meeting; and (6) shareholder pre-emptive rights. By no means is it here implied that these rights are unimportant, but they seem to supply only partial and sometimes easily outflanked safeguards, which have little to do with the protection of control and the entitlement to a control premium. As this Article suggests, dispersed ownership can persist only if the dispersed shareholders have the capacity to block an incoming control seeker from acquiring control without paying a control premium. Indeed, this fear of a premium-less acquisition of control was a major concern in the late nineteenth century well before the appearance of the modern tender offer. See infra text accompanying notes 90-91. 
If LLS\&V are correct, the implications of their research seem profoundly pessimistic for parts of the world seeking to develop deeper, more liquid securities markets. Absent sweeping legal changes, civil-law countries would seem condemned to concentrated ownership and thin securities markets. Not only might this legal barrier frustrate European efforts to develop a pan-European securities market, but its implications are even more significant and adverse for transitional economies. A growing body of research suggests that an active securities market is an engine for economic growth.' Must transitional economies therefore adopt the rules of common-law legal systems (and possibly common-law enforcement techniques) in order to develop their economies? Although a number of transitional countries have in fact begun to adopt U.S. corporate and securities laws, other researchers have warned that attempts to "transplant" law in this fashion have usually failed because the legal rules so adopted are incongruent with local customs and traditions. ${ }^{8}$

Nor are LLS\&V alone in predicting the persistence of the current bipolar division of the world into rival systems of dispersed and concentrated ownership. While LLS\&V argue that dispersed ownership cannot spread unless fundamental legal reforms protecting minority rights are adopted as a precondition, other recent commentators have advanced entirely independent reasons why dispersed ownership will remain the exception, with concentrated ownership being the rule. Lucian Bebchuk has advanced a "rent-protection" model of share ownership that posits that, when the private benefits of control are high, concentrated ownership will dominate dispersed ownership. ${ }^{9}$ The core idea here is that the entrepreneurs taking a firm public will not sell a majority of the firm's voting rights to dispersed shareholders in the public market, because they can obtain a higher price for such a control block from an incoming controlling shareholder or group, who alone can enjoy the private benefits of control. ${ }^{10}$

7. E.g., Asli Demirgüç-Kunt \& Vojislav Maksimovic, Law, Finance and Firm Growth, $53 \mathrm{~J}$. FiN. 2107 (1998) (finding that firms in countries with active stock markets were able to obtain greater funds to finance growth); Ross Levine \& Sara Zervos, Stock Markets, Banks, and Economic Growth, 88 AM. ECON. REV. 537 (1998) (relating economic growth to financial development); Maurice Obstfeld, Risk-Taking, Global Diversification and Growth, 84 AM. ECON. REV. 1310 (1994) (finding that the ability of investors to diversify through markets encourages growth); Raghuram G. Rajan \& Luigi Zingales, Financial Dependence and Growth, 88 AM. ECON. REV. 559 (1998) (finding that industries dependent on external finance are more developed in countries with better protection of external investors).

8. E.g., DANIEL BERKowitz ET AL., ECONOMIC DEVElopMENT, LEGALITY, AND THE TRANSPLANT EFFECT (SSRN Elec. Library, Working Paper No. 183,269, 2000), available at http://papers.ssm.com/paper.taf?abstract_id=183269.

9. LuCIAN Bebchuk, A Rent-PRotection Theory of Corporate OWNership AND CONTROL (Nat'l Bureau of Econ. Research, Working Paper No. 7203, 1999), available at http://www.nber.org/papers/7203; see also Bebchuk \& Roe, supra note 4 (predicting the persistence of concentrated ownership under certain conditions).

10. There are several possible answers to Professor Bebchuk's thesis. First, to the extent that the private benefits of control are enjoyed at the expense of the noncontrolling shareholders, the 
Thus, the control holder will sell only a minority interest or will sell control as a block, but will not break up its control block-and hence concentrated ownership will persist."

Similarly, Mark Roe has offered an entirely independent "political" theory for why strong securities markets are inconsistent with the European political tradition of "social democracy." ${ }^{2}$ In his view, social democracies pressure corporate managers to forego opportunities for profit maximization in order to maintain high employment. Under circumstances that would lead firms in other political environments to downsize their operations because of adverse market conditions, firms in social democracies, he argues, are compelled to expend their shareholders' capital in order to subsidize other constituencies. Public firms are relatively more exposed than private firms, he believes, to the higher managerial agency costs that social democracies impose. As a result, concentrated ownership is a defensive reaction to these pressures; through nontransparent accounting, hidden reserves, and direct supervision of management, large blockholders, he claims, can better resist these political pressures to expend the firm's resources on other constituencies.

In overview, a common denominator runs through the theories of LLS\&V, Bebchuk, and Roe: Ownership and control cannot easily separate when managerial agency costs are high. Although they disagree about the causes of high agency costs-i.e., weak legal standards versus political pressures that cause firms sometimes to subordinate the interests of shareholders-they implicitly concur that the emergence of deep, liquid markets requires that the agency cost problem first be adequately resolved by state action.

controlling shareholder's motive for paying a higher control premium than public shareholders is matched by their expected loss. To the extent that they can solve the coordination costs in organizing to protect themselves from a future controlling shareholder who will divest them of control, public shareholders may be able to match the premium that the large shareholder will pay for control. Second, in the case of high-risk investments, the public market affords investors the benefits of diversification, while the incoming controlling shareholder (or any large blockholder) must accept undiversified risk (and may not be willing to do so or may discount the price it offers to reflect this risk). Although this point about undiversified risk suggests that high-tech companies may obtain a higher price from the public market, as they long have on the Nasdaq (including many foreign issuers), it does not deny that the corporate controlling shareholder may often pay a higher premium in anticipation of synergy gains not available to portfolio or retail investors.

11. Studies of initial public offerings (IPOs) in concentrated securities markets have tended to confirm this prediction: IPOs seldom distribute more than a minority of the firm's voting shares to the market, with the controlling blockholder generally retaining control. For example, one recent study of Swedish IPOs finds that in close to $90 \%$ of all privately controlled IPOs, the controlling owner did not sell shares and controlled on average $68.5 \%$ of the voting power after the IPO.

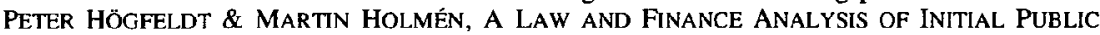
OFFERINGS 3-4 (SSRN Elec. Library, Working Paper No. 236,042, 2000), available at http://papers.ssm.com/paper.taf?abstract_id=236042.

12. Mark J. Roe, Political Preconditions to Separating Ownership from Control, 53 STAN. L. REV. 539 (2000). 
This Article dissents. Although it does not doubt that "law matters," it finds that a transition toward dispersed ownership is already well advanced and seems likely to continue, even in the short-term absence of legal change. Part I surveys this evidence, which reveals increasing signs of fission within the world of concentrated ownership. Despite the asserted barriers, securities markets are growing across Europe at an extraordinary rate, entrepreneurs in civil-law countries are making use of IPOs at a rate equivalent to that in the common-law world, and the market for corporate control has become truly international. Something is destabilizing the old equilibrium, but how far it will progress remains an open question.

Part II then analyzes the claim that securities markets require a strong legal foundation that protects the minority shareholder in order to become deep or liquid. Although the association between minority protection and liquidity seems real, Part II will argue that the cause and effect sequence is backwards. Much historical evidence suggests that legal developments have tended to follow, rather than precede, economic change. ${ }^{13}$ Specifically, Part II will examine the early development of the New York Stock Exchange (NYSE) and the London Stock Exchange (LSE), and contrast their experiences with the arrested development of equity securities markets in France and Germany over the same period. Although securities exchanges have existed since the seventeenth century, exchanges primarily traded debt securities up until the mid-nineteenth century. Then, over a relatively brief period and at a time when the private benefits of control were unquestionably high, dispersed ownership arose in both the United States and the United Kingdom-largely in the absence of strong legal protections for minority shareholders, which came afterward. Viewed in retrospect, this sequence makes obvious political sense: Legal reforms are enacted at the behest of a motivated constituency that will be protected (or at least perceives that it will be protected) by the proposed reforms. Hence, the constituency (here, dispersed public shareholders) must first arise before it can become an effective lobbying force and an instrument of legal change.

But how do liquid markets develop if minority shareholders are systematically exposed to expropriation by controlling shareholders because of inadequate legal protections (as LLS\&V conclude they are exposed)? A problem with much recent law and economics commentary on the natural predominance of concentrated ownership has been its ahistorical

13. Stuart Banner has made the interesting argument that, over the last 300 years, most major waves of securities regulation have followed a sustained price collapse on the securities market. Stuart Banner, What Causes New Securities Regulation?: 300 Years of Evidence, 75 WASH. U. L.Q. 849, 850 (1997). It is not surprising that "bubbles" and eventual crashes produce victims and hence a political demand for reform. But perhaps the deeper meaning of this finding is that the reform of securities regulation has not been associated with any broader political movement. Thus, this evidence is in tension with Professor Roe's claim that there are "political preconditions" to the growth of securities markets. See Roe, supra note 12. 
character. A closer look at the experience of U.S. corporations in the late nineteenth century shows that, even in the absence of adequate minority protections and even in the presence of high private benefits of control, private actors could bond themselves in ways that credibly signaled to the minority shareholders that they would not be exploited. Both through such bonding measures and through self-regulation, as implemented by the NYSE, investors were assured that their investments would neither be expropriated by the firm's founders nor, once ownership had become dispersed, subjected to a low-premium takeover by an incoming control seeker. That the United States led the way toward dispersed ownership seems best explained not by the state of its nineteenth-century corporate law, but by a more basic fact: As a debtor nation facing the need to develop highly capital-intensive industries (e.g., railroads, steel, and electrical power), the United States was more dependent upon foreign capital, and it had to strive harder to convince remote foreign investors of the adequacy of the safeguards taken to protect their investments.

Dispersed ownership did not, however, arrive in France or Germany, even though the Paris Bourse was the leading international rival to the LSE during the last quarter of the nineteenth century. Why not? The "political thesis" offered by Roe clearly cannot explain the failure of securities markets to develop in France and Germany during the late nineteenth century, because neither country approached being a social democracy in this era. ${ }^{14} \mathrm{~A}$ possible explanation could be that offered by LLS\&V, namely, that French and German law provided insufficient protections for minority shareholders. But the LLS\&V explanation has a serious problem: The specific "anti-director" rights that they identify as the central factors distinguishing common-law from civil-law systems strike many legal commentators as only tangentially related to effective legal protection for minority shareholders. ${ }^{15}$ The possibility thus surfaces that the observed legal differences identified by LLS\&V may serve as a proxy for something deeper.

What, then, is the hidden variable that at least historically distinguished common-law from civil-law systems? Part III suggests that the principal variable accounting for the earlier development of dispersed ownership in the United States and the United Kingdom than in Continental Europe was

14. For example, no matter how Prince Otto von Bismarck, the leading German statesman and politician of the last half of the nineteenth century, is characterized, he was not a social democrat. See WOLFGANG J. MOMMSEN, IMPERIAL GERMANY, 1867-1918 (Richard Deveson trans., 1995); see also infra notes 208-210 and accompanying text (discussing this period). Correspondingly, the dominant figure behind French efforts to develop a system of international investment banking in the late nineteenth century was Napoleon III, who was the sponsor of Crédit Mobilier, the first major investment bank organized on a corporate basis. See infra notes 160-162 and accompanying text. His motives were, however, largely statist, rather than economic.

15. For a description of LLS\&V's “ anti-director” rights, see supra note 6. 
the early separation of the private sector in the common-law world from the close supervision and control of the central government. In the absence of direct governmental regulation, relatively strong systems of self-regulation arose in the United States and the United Kingdom, which were administered by private bodies (most notably, private stock exchanges) that sought to regulate their members' conduct in their mutual self-interest. Although these exchanges may not have been optimal regulators, they were at least entrepreneurial entities that adapted quickly to new conditions and opportunities. In contrast, in France and, to a lesser extent, in Germany, the state intervened constantly in the market, sometimes to protect it and sometimes to chill it, but the degree of paternalistic supervision that was imposed froze the development of Continental markets and left little room for enlightened self-regulation.

Viewed in this light, the critical role of law in the separation of ownership and control was not that it fostered minority shareholders (in common-law countries) or abandoned them (in civil-law countries), but rather that the common-law world was, for a variety of reasons, more hospitable than the civil-law world to private self-regulatory institutions. ${ }^{16}$ If the common law has a more decentralized character that encourages private law-making, while the civil law tends to be more centralized and hostile to private law-making, this difference transcends the field of comparative law and has contemporary relevance for planners and regulators in transitional economies. As will be stressed, it suggests that private action, through bonding and signaling measures, may be the critical first step toward stronger securities markets.

This proposed interpretation, which deemphasizes the role of formal law, agrees with LLS\&V that it was not coincidental that liquid equity securities markets arose in the United States and the United Kingdom, but not in France or Germany, but disagrees with them that the key explanatory variable was the impact of the substantive law on shareholder rights. Because this interpretation focuses less on substantive law, and more on the structure for lawmaking within the broader society, it is not confounded by the special case of the Netherlands, where securities markets first arose in Amsterdam well ahead of London. Although the Netherlands is a civil-law country, the critical fact explaining the early appearance of securities markets there in this Article's view was that it was, much like England, a pluralistic, decentralized society in which the private sector was relatively

16. This thesis that decentralization encouraged economic growth has been developed on a grander scale by the British historian and anthropologist Alan Macfarlane. See generally ALAN MACFARLANE, THE ORIGINS OF ENGLISH INDIVIDUALISM (1978) [hereinafter MACFARLANE, ORIGins]; Alan MacFarlane, The RIDDLE OF THE MODERN WORLD (2000) [hereinafter MACFARLANE, RIDDLE]; infra notes 225-229 and accompanying text. 
autonomous and free from direct state supervision. ${ }^{17}$ Moreover, if legal protections of minority shareholders were the indispensable precondition for the growth of securities markets, as LLS\&V posit, the successful U.S. experience would seem inexplicable. As will be seen, in the late nineteenth century, U.S. law was characterized by a high level of judicial corruption, was demonstrably vulnerable to regulatory arbitrage (as participants in corporate control battles regularly played one court and one state off against another), and wholly lacked any federal law on securities regulation. Given that the private benefits of control were high and realistic minority protections were weak, the LLS\&V model would predict that dispersed ownership could not arise in such an environment. But it did.

That dispersed ownership was able to arise in this era derived in large measure from the ability of private actors to develop functional substitutes for formal law. ${ }^{18}$ Over time, the systems of securities regulation in the United States and the United Kingdom functionally converged. Only later did legislative changes bring about formal convergence. That functional convergence should precede formal convergence is even more predictable in a rapidly globalizing world in which competitive pressures in the increasingly international capital and product markets compel firms to adapt and penalize those firms that have a higher cost of capital. ${ }^{19}$ Thus, Part III predicts that functional convergence may be the principal mechanism by which the separation of ownership and control will come both to Europe and, more slowly, to transitional economies. Specifically, it suggests that some recent developments in Russian corporate governance are functional parallels to the bonding and signaling devices used in the United States in the 1870 s and 1880 s, and that some European stock exchanges are beginning to show today the same activism that the NYSE

17. This same point that the United Kingdom and the Netherlands had a similar social structure, but different legal origins, has been well made by Alan Macfarlane. See MACFARLANE, RIDDLE, supra note 16 , at $279-80$.

18. In earlier work, I distinguished "formal convergence" from "functional convergence." John C. Coffec, Jr., The Future as History: The Prospects for Global Convergence in Corporate Governance and Its Implications, 93 Nw. U. L. REV. 641,657 (1999). Formal convergence requires multiple jurisdictions to enact common legal rules and practices. Functional convergence can arise, however, because of the use of functional substitutes that look dissimilar but have equivalent effects. Functional convergence can also be achieved as the result of private actions, such as bonding devices or related actions that deliberately limit managerial discretion. For example, a firm in a country with weak legal rules and disclosure standards might deliberately list on the NYSE in order to subject itself voluntarily to its higher disclosure, accounting, and market transparency standards and to the enforcement mechanisms that apply to firms that enter the United States market (that is, private class actions and SEC enforcement). Such bonding through cross-listing on a foreign exchange has recently become common and appears to increase the firm's stock price. Id. at 673-75.

19. Professors Hansmann and Kraakman emphasize this point at some length, arguing that as a result a norm of shareholder primacy is becoming dominant worldwide. Hansmann \& Kraakman, supra note 3. 
displayed at the end of the nineteenth century. If it is too much to claim that it is "déjà vu, all over again," the parallels are at least striking.

Finally, Part III challenges the "political thesis" that social democracy and strong securities markets cannot co-exist. Others have also challenged this very ambitious claim, noting that England supplies a strong counterexample of social democracy co-existing with strong securities markets. ${ }^{20}$ This Article will advance a more general objection: Financial institutions-including the much-used example of German universal banks-do not operate as buffers that can protect shareholder interests from social-democratic pressures. Rather, because large financial intermediaries tend to be state controlled (directly or indirectly), they are likely to be more exposed to political pressures to subordinate shareholder interests. Even large blockholders are more visible and exposed than anonymous small shareholders, who themselves can constitute a significant political interest group. As politicians in democracies with dispersed ownership have repeatedly found, political actions that cause (or are perceived to cause) a stock market decline are painful and self-disciplining. Concentrated ownership, then, may survive not because large financial intermediaries are good monitors or politically less vulnerable, but because the status quo favors incumbent interest groups against new entrants who wish to compete. Further, as I have elsewhere argued, ${ }^{21}$ institutions seem to prefer liquidity to control. As a result, concentrated ownership is no more a natural state than is dispersed ownership, but is the artifact of a particular set of legal controls and political pressures. More importantly, across Europe today, financial institutions appear on the verge of liberation-and seem delighted at the prospect of being able to liquidate their controlling blocks.

Ultimately, the policy message of this Article is optimistic. While formidable obstacles may exist to the development of liquid securities markets, both in transitional economies and in civil-law countries, a wholesale transplantation of common-law rules is not necessary. Self-help measures, including exchange self-regulation, can potentially provide functional substitutes that significantly compensate for any deficit in minority protection that the use of civil-law standards entails. This does not mean that substantive law reform is unimportant, or that self-regulation can provide a fully adequate substitute for public law enforcement, but only that adaptive strategies can be designed for nations, individual markets, and individual firms. What is most important for the emergence and survival of dispersed ownership in new legal environments is that public shareholders

20. E.g., Brian R. Cheffins, Putting Britain on the Roe MaP: The Emergence of the BERLE-MEANS CORPORATION IN THE UNITED KINGDOM (SSRN Elec. Library, Working Paper No. $218,655,2000$ ), available at http://papers.ssrn.com/paper.taf?abstract_id=218655.

21. John C. Coffee, Jr., Liquidity Versus Control: The Institutional Investor as Corporate Monitor, 91 COLUM. L. REV. 1277 (1991). 
be able to hold control against the attack of the control seeker who wishes to avoid paying a control premium. As will be seen, the United States and the United Kingdom have developed independent and divergent techniques to address this problem, the former relying on the shareholders' agents (the board of directors) to protect their right to a control premium, ${ }^{22}$ and the latter relying on mandated collective action (a shareholder vote). ${ }^{23}$ This divergence illustrates a central theme of the Article: There is not a single common-law solution to the most important problems of corporate law, but rather multiple functional substitutes.

\section{THE EVIDENCE ON CONVERGENCE}

Attempts to describe an ongoing transition in corporate governance and structure are always vulnerable to the criticism that they rely on anecdotal evidence. By now, however, the available evidence is substantial and involves quantitative as well as qualitative data. For the sake of convenience, the most salient evidence can be grouped under the following four categories. Although the transition is far from complete, the collective weight of the evidence suggests that a new equity culture has received de facto (if not yet formal) acceptance across Europe, with both investors and regulators seeking to encourage its development. That such a transition has occurred in the absence of sweeping legal changes, or any apparent shift within Continental Europe toward common-law legal standards, seems at least mildly inconsistent with the LLS\&V thesis.

\section{A. Formal Legal Change}

Formal legal change is the area where those adopting a path-dependent perspective have suggested that change would be the slowest and most

22. 'The board of directors' obligation to obtain a control premium for its shareholders before it allows control to pass from public shareholders to a new controlling shareholder is a thread that runs through much Delaware case law. See Paramount Communications, Inc. v. QVC Network, Inc., 637 A.2d 34, 42-45 (Del. 1993); Barkan v. Amsted Indus., Inc., 567 A.2d 1279, 1286 (Del. 1989); Mills Acquisition Co. v. Macmillan, Inc., 559 A.2d 1261, 1288 (Del. 1988).

23. In contrast to U.S. law, British law discourages most defensive tactics in corporate control battles, but it does restrict the potential control acquirer's ability to make a coercive, partial bid. Specifically, British takeover law imposes a buyout obligation on the control buyer under which it must offer to buy out the remaining minority shareholders at the same price as it paid to the control seller. See Deborah A. DeMott, Comparative Dimensions of Takeover Regulation, 65 WASH. U. L.Q. 69, 94 (1987). Specifically, under the City Code on Take-Overs and Mergers, which is a self-regulatory code, a tender offer for more than thirty percent and less than a hundred percent is precluded unless first approved by a majority vote of the shareholders. $I d$. at 93-94. In short, British law and U.S. law both protect the public shareholder's right in some circumstances to share in a control premium, but they use totally divergent approaches, not a unified common-law approach. 
marginal, ${ }^{24}$ because formal legal change generally requires legislative action and can be blocked by political interest groups or strongly motivated minorities (who may have little concern with overall efficiency). Still, even here, significant change is evident.

The clearest evidence relates to the transition economies. Employing a methodology that uses cross-country formalized legal indicators to measure statistically the degree of legal change, Katharina Pistor constructed a database covering twenty-four transition economies (namely, most of the formerly socialist states in Europe and Eurasia) that tracked the development of shareholder and creditor rights from 1990 through $1998 .^{25}$ She concluded: "Despite substantial differences in the initial conditions across countries, there is a strong tendency towards convergence of formal legal rules as the result of extensive legal reforms." ${ }^{26}$ She notes, however, that "law reform has been primarily responsive to economic change rather than initiating or leading it." ${ }^{27}$ As discussed later, this same pattern appears to be evident in the development of diffused securities markets in both the United States and the United Kingdom.

The direction of these changes has been uniformly in the "AngloSaxon" direction: "By 1998, legal changes had been introduced that raised the level of investor protection in most transition economies above the level of the civil law systems and brought them within close range of the average for common law countries ....,"28

In overview, this transition seems largely to have involved the outright substitution of common-law rules for civil-law rules, with the total package of legal reforms usually designed by foreign legal advisors (often supplied by the United States). Still, because these reforms have been legislatively adopted, this wholesale transplantation seems to indicate that, at least under the pressures faced by transition economies, lawmakers have not felt

24. Bebchuk and Roe properly argue that legal rules are the product of political processes. To the extent that interest groups play a role in such processes, the corporate legal rules that are chosen are likely to reflect the relative strength of the relevant interest groups. Bebchuk \& Roe, supra note 4 , at $157-58$. In particular, controlling shareholders who enjoy substantial private benefits of control in countries characterized by concentrated ownership will wish to maintain the existing legal rules that favor their interests, even if a different ownership structure would be more efficient. Id. at 158 .

Arguably, the data in this Section is consistent with the Bebchuk and Roe prediction, because the most rapid and thoroughgoing formal legal changes have occurred in transitional economies, where strongly entrenched interests that were aligned with the existing legal structure did not already exist.

25. Katharina Pistor, Patterns of Legal Change: Shareholder and CREditor RIGHTS IN TRANSITION ECONOMIES (Eur. Bank for Reconstruction \& Dev., Working Paper No. 49/2000, 2000), available at http:/www.ebrd.com/english/region/workingp/wp49.pdf.

26. Id. at 2 .

27. Id.

28. Id. at 13 . 
obliged to maintain continuity with their historical legal systems. Radical legal change is at least sometimes possible.

A possible response to the evidence of sharp discontinuity in the law of transitional economies is that mass privatization programs in these countries imposed a diffused, Anglo-Saxon structure of share ownership on these countries and so required a corresponding movement to Anglo-Saxon (or common-law) systems of corporate governance and securities regulation. From this perspective, one might argue that no similar rate of legal change should be predicted for those economies in which an insiderdominated system of concentrated ownership already prevailed. In short, if form follows function (that is, if legal rules are determined by the system of corporate governance that preexists those rules), then no similar rapid legal transition should necessarily be expected in the Continental economies in which concentrated ownership is still the norm.

The actual picture is, however, more mixed. Rather than individual states modifying their own individual statutes, law reform within the European Community has proceeded largely on the basis of efforts at harmonization. ${ }^{29}$ That is, a Company Law directive will be proposed (after much negotiation) by the European Union's Council of Ministers, and an effort will then be made to secure its ratification by member states. Although such efforts have regularly succeeded in other private law areas, they have elicited major struggles in the corporate law area. Throughout the 1980 s, efforts by the European Union to adopt directives dealing with takeover bid procedures, codetermination, and employee rights all failed amidst considerable ideological controversy about the place of the private corporation in European society. ${ }^{30}$ Yet contemporaneously, the European Union adopted a variety of securities-oriented directives intended to integrate disclosure and transparency standards in order to facilitate a panEuropean securities market. ${ }^{31}$ In short, while the old battles over codetermination and workers' rights continue, little, if any, opposition surfaces to directives intended to develop securities markets or improve disclosure standards. Again, this suggests that at least the goal of liquid securities markets has become a "motherhood issue" with no active opponents.

29. For an overview of this process, see Coffee, supra note 18, at 667-70. See also Uri Geiger, Harmonization of Securities Disclosure Rules in the Global Market-A Proposal, 66 FORDHAM L. REV. 1785 (1998) (describing and evaluating efforts at harmonization).

30. Coffee, supra note 18, at 668-69; Amir N. Licht, International Diversity in Securities Regulation: Roadblocks on the Way to Convergence, 20 CARDOzO L. REV. 227, 239-40 (1998).

31. Geiger, supra note 29, at 1789-90. 


\section{B. The Structure of Share Ownership}

Considerable evidence exists that the traditional system of concentrated ownership is at least marginally weakening across Europe. Data compiled by the Conference Board shows a measurable decline in the stakes held in the twenty-five largest corporations by banks and nonfinancial corporations in Germany, France, and Japan. ${ }^{32}$ Traditionally, these holders were the allies of the founding families and managements that ran the largest European and Japanese companies. Yet, over just a one-year period between September 30, 1998, and September 30, 1999, these traditional stakeholders unwound their holdings to the following degree:

\section{TABLe 1. Closely Held OWNERShIP IN THE TWENTY-Five LARGeST CORPORATIONS ${ }^{33}$}

\begin{tabular}{|l|c|c|}
\hline & September 30,1998 & September 30, 1999 \\
\hline France & $33.5 \%$ & $30.2 \%$ \\
\hline Germany & $24.2 \%$ & $17.8 \%$ \\
\hline Japan & $21.2 \%$ & $14.0 \%$ \\
\hline
\end{tabular}

Of course, a one-year trend may be unrepresentative, and these data do not demonstrate that the shares so unwound necessarily moved into the hands of public investors. Yet, there is also evidence of a substitution effect - that is, the shares are passing into the hands of more active owners. Thirty-five percent of the outstanding shares of the forty largest companies on the Paris Bourse are now held by American and British institutional investors. ${ }^{34}$ Over this same period, U.S. institutional investors have dramatically increased their investments in foreign equity. The largest twenty-five U.S. pension fund holders of international equity held $\$ 110.8$ billion in foreign equities in 1996, $\$ 181.1$ billion in 1998 , and $\$ 265.6$ billion in September, 1999 - a nearly $150 \%$ increase in only two years. ${ }^{35}$ With this heightened ownership comes, of course, a demand for additional voice.

More importantly, many expect that this rate of change will soon accelerate, at least in some of the largest and most traditional European economies. In Germany, a high capital gains tax locked financial

32. Carolyn Kay Brancato, Corporations Outside U.S. Become More Subject to Investor Demands, CORP. GOVERNANCE ADVISOR, July-Aug. 2000, at 1.

33. Id.

34. John Tagliabue, Resisting Those Ugly Americans, N.Y. TIMES, Jan. 9, 2000, § 3, at 10.

35. Brancato, supra note 32 , at 1. 
institutions into their elaborate web of cross-shareholdings because any attempt to liquidate these blocks would have been punitively taxed. ${ }^{36}$ Yet effective January 1,2002, the capital gains tax on such investments will be eliminated, and some of the largest German financial institutions have already announced plans to reduce the extent of their cross-shareholdings. ${ }^{37}$ The apparent eagerness of German financial institutions to divest themselves of long-held blocks and to scale back noncore assets raises the always-lurking question about how deeply the German system of concentrated ownership was truly entrenched. Professor Roe, among others, has suggested that concentrated ownership (and correspondingly weak securities markets) reflects a strong social and political commitment to a cluster of social values that he calls "social democracy." 38 Yet, if a simple change in the corporate tax laws causes the system to collapse by the mutual consent of those locked into this system of cross-shareholdings, the simpler explanation for concentrated ownership may be that German tax laws either caused this system, or, more likely, enforced its persistence well after competitive forces would otherwise have compelled its dismantling. ${ }^{39}$

\section{The Growth of European Stock Markets}

Continental stock markets have long been thin and illiquid. For some, this was arguably a virtue of European corporate governance because it protected corporate managements from the tyranny of a "short-sighted" stock market and instead permitted long-term business planning by corporations in conjunction with their principal stakeholders. ${ }^{40}$ Whatever the historical validity of this story, it now seems increasingly dated.

A particularly useful recent study shows that the number of firms listing on European stock changes rose sharply at the end of the 1990s: ${ }^{41}$

36. Haig Simonian, Germany Unbound: Measures To Reduce the Country's Restrictive Tax Burden Have Delighted Many Businesses, Fin. TIMES (London), Aug. 10, 2000, at 14.

37. Id. (noting the plan of Allianz and Munich Re to reduce their cross-holdings).

38. Roe, supra note 12 , at 543 .

39. German scholars have also suggested that the German tax system may be the better explanation for at least the contemporary system of concentrated ownership in Germany. E.g., Friedrich Kübler, On Mark Roe, German Codetermination and German Securities Markets, 5 COLUM. J. EUR. L. 213, 214-15 (1999).

40. Some observers wholly disagree with LLS\&V and consider concentrated ownership to be more efficient, in part because managers possess information that market participants lack. See

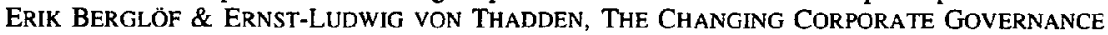
PARADIGM: IMPLICATIONS FOR TRANSITION AND DEVELOPING COUNTRIES 14 (SSRN Elec. Library, Working Paper No. 183,708, 1999) (noting the "popular view" that "outside investors do not necessarily take into account the long-term interest of the firm"), available at http://papers.ssm.com/paper.taf?abstract_id=183708.

41. Christoph VAN DER Elst, THE Equity MARKETS, OWNERShIP STRUCTURES AND CONTROL: TOWARDS AN INTERNATIONAL HARMONISATION? (Fin. Law Inst., Working Paper No. WP 2000-04, 2000), available at http://system04.rug.ac.be/fli/WP/wp2000-04.pdf [hereinafter VAN DER ELST, EQUITY MARKETS]. This paper is a preliminary version of a Ph.D. dissertation in 
TABLE 2. EVOlution OF THE NuMBER OF STOCK EXCHANGE LiSTED COMPANIES $^{42}$

\begin{tabular}{|l|r|r|r|r|r||}
\hline & 1990 & 1993 & 1996 & 1999 & $\begin{array}{c}\text { \% Growth } \\
(1990- \\
1999)\end{array}$ \\
\hline Network-oriented: & & & & & \\
\hline Belgium & 182 & 159 & 136 & 140 & $-23.1 \%$ \\
\hline $\begin{array}{l}\text { France } \\
\text { ('excluding Marche Libre) }\end{array}$ & 443 & 726 & 686 & ${ }^{2} 968$ & $118.5 \%$ \\
\hline Germany & 548 & 568 & 579 & 1043 & $90.3 \%$ \\
\hline Italy & 257 & 242 & 244 & 247 & $-3.9 \%$ \\
\hline Netherlands & 222 & 239 & 217 & 233 & $5.0 \%$ \\
\hline $\begin{array}{l}\text { Spain } \\
\text { (1992) }\end{array}$ & 429 & ${ }^{\mathrm{b}} 404$ & 357 & 718 & $67.4 \%$ \\
\hline $\begin{array}{l}\text { Japan (Tokyo) } \\
\text { (1998) }\end{array}$ & 1627 & 1667 & 1766 & ${ }^{\mathrm{c}} 1838$ & $13.0 \%$ \\
\hline Market-oriented: & & & & & \\
\hline United Kingdom & 1946 & 1927 & 2339 & 2292 & $17.8 \%$ \\
\hline United States (NYSE) & 1774 & 1945 & 2476 & 2631 & $48.3 \%$ \\
\hline United States (Nasdaq) & 3876 & 4310 & 5167 & 4829 & $24.6 \%$ \\
\hline
\end{tabular}

Although the pattern is far from uniform, listings on the equity market rose rapidly in the late 1990s in France, Germany, and Spain, more rapidly than in the United States or the United Kingdom. Elsewhere, the number of listed companies may have declined, possibly because of an international wave of mergers and acquisitions, which is itself a sign of convergence.

Beyond this growth in the number of listed companies, two other statistics reveal even more clearly the suddenly increased role of the equity markets in European economies, a transition that again seems to date only from the latter half of the last decade. First, stock market capitalization as a percentage of GDP skyrocketed in several European countries-indeed, to the point that one or two European countries approach or exceed the same ratios in the United States or the United Kingdom. The following selected

Dutch. Christoph Van der Elst, Aandeelhoudersstructuren, Aandeelhoudersconcentratie en Controle Van Beursgenoteerde Ondernemingen (2001) (unpublished Ph.D. dissertation, Universiteit Gent) (on file with author) [hereinafter Van der Elst, Dissertation].

42. Van der Elst, Dissertation, supra note 41, at tbl.3.1. 
examples show how long-stable percentages veered suddenly upward at the end of the decade.

Table 3. Evolution of Market Capitalization as a Percentage OF GDP (1990-1999) ${ }^{43}$

\begin{tabular}{|l|r|r|r|r|r|r|}
\hline & 1975 & 1980 & 1990 & 1996 & 1998 & 1999 \\
\hline Network-oriented: & & & & & & \\
\hline Belgium & $15 \%$ & $8 \%$ & $33 \%$ & $44 \%$ & $97.5 \%$ & $75.4 \%$ \\
\hline France & $10 \%$ & $8 \%$ & $26 \%$ & $38 \%$ & $67.8 \%$ & $105.3 \%$ \\
\hline Germany & $12 \%$ & $9 \%$ & $22 \%$ & $28 \%$ & $50.6 \%$ & $68.1 \%$ \\
\hline Italy & $5 \%$ & $6 \%$ & $14 \%$ & $21 \%$ & $47.9 \%$ & $62.4 \%$ \\
\hline Netherlands & $21 \%$ & $17 \%$ & $42 \%$ & $95 \%$ & $157.6 \%$ & $177.3 \%$ \\
\hline Spain & - & $8 \%$ & $23 \%$ & $33 \%$ & $71.9 \%$ & $72.6 \%$ \\
\hline Sweden & $3 \%$ & $10 \%$ & $40 \%$ & $95 \%$ & $122.3 \%$ & $156.3 \%$ \\
\hline Switzerland & $30 \%$ & $42 \%$ & $69 \%$ & $136 \%$ & $259.4 \%$ & $267.5 \%$ \\
\hline Market-oriented: & & & & & & \\
\hline United Kingdom & $37 \%$ & $38 \%$ & $87 \%$ & $142 \%$ & $167.3 \%$ & $198.0 \%$ \\
\hline United States & $48 \%$ & $50 \%$ & $56 \%$ & $114 \%$ & $157.0 \%$ & $181.1 \%$ \\
\hline \hline
\end{tabular}

Of course, these percentages are subject to greater fluctuation in countries with small populations (such as the Netherlands and Switzerland), and much of the market capitalization in these countries may remain in the hands of a few controlling owners. Nonetheless, the real point is the suddenness of the transition. Essentially, as the European market integrated in the mid-1990s, stock market values soared, both in absolute terms and as a percentage of GDP.

Second, while IPOs once characterized only the markets of the United States and the United Kingdom, they have become common across Europe. In 1999, Germany saw 168 IPOs, and France saw 75. For the decade, France led with 581 IPOs, Germany followed with 380 , and Spain was a close third with $355^{44}$ The significance of this point bears emphasis because systems of concentrated ownership were thought to lack the institutions necessary to bring new companies directly into the equity market. Instead, new firms were believed to be dependent on bank and debt

43. Id. at tbl.3.4.

44. Id. at tbl.3.5.

Imaged with the Permission of Yale Law Journal 
financing, not equity finance. Yet, by the end of the decade, several European countries were raising more equity through initial public offerings as a percentage of GDP than were either the United States or the United Kingdom. ${ }^{45}$

There is a double-edged significance to these findings. On the one hand, by the end of the last decade, the stock market was raising equity capital for European issuers at levels (and percentages of GDP) that were thought to characterize only market-oriented systems of corporate governance (i.e., the United States and the United Kingdom). But on the other hand, this sudden surge in the use of equity finance has been unaccompanied by any significant increase in the legal protections afforded to minority shareholders. In this sense, both the "path dependency" theorists, who maintain that the stock market cannot grow in social democracies, and the economists (most notably, LLS\&V), who maintain that the availability of equity finance depends on minority protections, appear to have been confounded. Neither the "path dependency" claim nor the assertion that "law matters" can draw unambiguous support from this evidence.

It is also clear that new market institutions and structures are appearing. A race has begun to create the first pan-European stock market. Easdaq, which began trading as a pan-European exchange in November 1996, was unable to establish itself as a viable market, ${ }^{46}$ but was recently acquired by Nasdaq in a move that will clearly intensify competition. ${ }^{47}$ The German Neuer Markt, which serves over 300 listings, has been far more successful ${ }^{48}$ But even its success is now being tested by a worldwide stock market decline following the crash of the Nasdaq in 2000. Between March 2000 and April 2001, price levels on the Neuer Markt proved even more volatile than those on the Nasdaq and fell by an estimated eighty-three percent. ${ }^{49}$ The public response has not been a rejection of the new equity culture, but rather a demand for more regulation and higher listing

45. Van der Elst finds that both the Netherlands and Spain raised significantly more equity capital in IPOs as a percentage of GDP than did the United States or the United Kingdom. VAN DER ELST. EQUITY MARKETS, supra note 41, at 10. This is not simply an artifact of small GDP size, as in 1999 Germany raised equity capital equal to $1.02 \%$ of its GDP through IPOs, while the United Kingdom raised only $0.6 \%$, and the United States raised $1.23 \%$. Id.

46. As of mid-2000, Easdaq had only been able to secure some sixty-two listings. Craig Karmin, Europe's Easdaq Finds That Success Doesn't Come Easy, WaLl St. J., Aug. 14, 2000 , at $\mathrm{C} 1$.

47. Silvia Ascarelli, Nasdaq Confirms Its Acquisition of Easdaq Stake, WALL ST. J., Mar. 28, 2001 , at C14.

48. See Karmin, supra note 46. at $\mathrm{Cl}$.

49. Silvia Ascarelli, Europe's Faith in Stocks Gets Put to the Test, WALL ST. J., Apr. 9, 2001, 
standards. ${ }^{50}$ Thus, a familiar pattern-crash, then law-is once again reappearing.

To sum up, the equity culture is still less established in Europe than it is in the United States, and a much smaller percentage of the general European population owns shares than is the case in the United States. ${ }^{51}$ Nonetheless, the current ownership levels in nations such as Germany probably exceed those in the United States in the early twentieth century when dispersed ownership first arrived..$^{52}$

\section{The Emergence of an International Market for Corporate Control}

In market-centered economies, the market for corporate control is the ultimate disciplinary mechanism, and the hostile takeover, its final guillotine. In contrast, in concentrated ownership systems of corporate governance, the takeover has historically played only a minor role. But, once again, that pattern appears to be changing rapidly. In $1985,86 \%$ of all takeovers involved at least one American party, but in 1999, this percentage fell to only $40 \% .{ }^{53}$ Over the same time span, the percentage of corporate takeovers involving at least one European party rose from $15 \%$ to $43 \%$, and the percentage involving an Asian party rose from approximately $2 \%$ to nearly $14 \% .{ }^{54}$ If one looks instead to the market value of these transactions, takeovers involving a European party have gone from $11 \%$ of the world total in 1985 to $47 \%$ in $1999 .{ }^{55}$ Evidence of this sort has led some scholars to describe the last two years as amounting to the "First International Merger Wave." 56

What is driving this transition? One answer starts with the integration of European currencies into the Euro. A consequence of a single, unified currency has been the growth of a unified European corporate bond market, which tripled in size last year and has thereby ended the dependence of European acquirers on bank financing. ${ }^{57}$ Acquirers can now directly access

50. See Neal Bondette \& Alfred Kueppers, Frustrated Neuer Markt Members Push for Tightening Listing Rules, WALL ST. J., July 11, 2001, at C12 (noting that even issuers on the Neuer Markt want tighter regulation). For the observation that European investors are not dumping their shares or disinvesting, see Ascarelli, supra note 49.

51. For example, in Germany, it is now estimated that $9.7 \%$ of Germans own shares directly and $13.7 \%$ own through mutual funds, while in the United States, roughly $50 \%$ of citizens own stocks. Id.

52. While the percentage of Americans who own stocks appears to be around $50 \%$, it was recently much lower. In 1995, $41.1 \%$ of U.S. families owned stock directly, and in 1989 that level was only $31.7 \%$. Richard W. JENNINGS ET AL., SECURITIES REgUlation 3 (8th ed. 1998).

53. Bruce Stokes, The M\&A Game's Global Field, 32 NAT'L J. 2290 (2000).

54. Id.

55. Bernard S. Black, The First International Merger Wave (and the Fifth and Last U.S. Wave), 54 U. MIAMI L. REV. 799, 801 (2000).

56. Id. at 800 .

57. See Stokes, supra note 53 , at 2291 . 
the capital markets, offering either debt, equity, or a package of both. To this extent, the growth of the takeover market has been concomitant with the declining role of the universal bank.

For some time, the legitimization of the hostile takeover seemed about to be officially recognized with the scheduled adoption of the Thirteenth Company Law Directive by the European Union. As approved by the European Union's Council of Ministers in mid-2000, that directive required all EU member states to legislate (over four years) to bar most anti-takeover defensive measures after a takeover has been announced. ${ }^{58}$ But the Council's action proved not to be the end of the story. An unexpected snag was hit when the European Parliament split evenly on a vote to approve the directive, thereby rejecting the measure.$^{59}$ Although this development again demonstrates the continuing ideological dimension in corporate law reform, acceptance of the takeover as a mechanism of corporate governance appears to have arrived at least on a de facto basis within the European business community. Indeed, the passivity of a German labor government in the face of a hostile takeover bid by a British acquirer (Vodafone) for a German target (Mannesmann) in 1999 demonstrated this change in attitude (at least for Germany). Only in a few countries (most notably, the Netherlands and France) does real opposition remain, and even there the objection is more to the foreign character of the bidder, not the use of the takeover device itself. Finally, a common international business culture has at least begun to develop around the use of the takeover. A wave of international mergers between law firms (chiefly between U.S. and British firms as well as British and German firms) appears to have been driven by the perceived need to effect cross-border acquisitions.

\section{E. A Preliminary Evaluation}

Why now? The integration of Europe has been in progress for several decades, and the emergence of the transitional economies in the wake of the

58. After much delay, the Council of Ministers adopted the Thirteenth Company Law Directive in June 2000. See European Union Agrees to Common Takeover Rules, FIN. TIMES, June 20, 2000, at 11; Christopher Swann, The Weak Will Become Prey, FIN. TIMES, June 30, 2000 , at 4 . The proposed directive did permit shareholders to vote to approve defensive tactics.

59. The tied vote was 273 for to 273 against, with a number of abstentions. An absolute majority was required for passage. See Company Law: Parliament No Vote Shreds Takeover Directive, EUR. REP., July 6, 2001. It is anticipated that a revised takeovers directive will be submitted by the European Commission to the European Parliament in 2002, but it will have to address newly controversial issues involving "golden shares" (i.c., large blocks of shares retained by the state in privatizations) and voting limitations, and thus the directive may have to be significantly diluted to secure passage. See Company Law: Makeover of the Takeover Directive Unlikely Before 2002, EUR. REP., July 14, 2001. The sudden increase in the opposition to the takeover directive seems best explained by late-developing anxieties in Germany, where a major sell-off of controlling stakes held by German financial institutions is expected. See supra note 37 and accompanying text. 
collapse of the Soviet Union is itself over a decade old. Why have stock markets suddenly surged, takeovers become accepted, and IPOs crested? Both a psychological and a political account seem necessary. Overused as the concept is, a paradigm shift seems in progress.

At the political level, one possible story is that regulators came to sense that economic growth depended on the encouragement of venture capital and high-tech start-up firms. Bank financing for such ventures is generally unavailable and also unattractive to the entrepreneurs. In this light, the success of the Neuer Markt (and other incubator stock markets) was necessary if Europe was not to fall rapidly behind the United States. From this perspective, policy planners saw at least some transition to a marketcentered economy as central to economic growth. Yet, even if this story sounds plausible, regulators have in reality done relatively little to drive the foregoing transition.

The closer one looks at the European evidence, the more viewing law as controlling the structure of finance seems like a simplistic theory of causality; rather, the relationship has been more reciprocal and interactive. The Thirteenth Company Law Directive (known popularly as the "Takeovers Directive") may be a leading case in point. Rather than leading a movement, it seems to be slowly following in the wake of changes that have already received de facto acceptance (at least throughout the corporate community of Europe). Similarly, there is evidence that insider trading prohibitions have recently been widely adopted around the world, but in the wake of greater depth and diffusion in securities markets. ${ }^{60}$

But what fundamental economic and financial changes could have disturbed the old equilibrium and thereby set in motion processes that eventually produced the new equity culture? Rajan and Zingales have developed strong statistical evidence that openness to trade and the liberalization of cross-border capital flows were the hidden causal forces that have recently spurred financial development in Europe after decades of stagnation. ${ }^{61}$ While the United States opened up to cross-border capital flows in the mid-1970s, and the United Kingdom and Japan similarly turned the corner around 1980, the nations of Continental Europe lowered their barriers only in the late $1980 \mathrm{~s}^{62}$ But as they did, market capitalizations soared, and barriers to entry ceased to be politically defended. ${ }^{63}$ Equally important and roughly contemporaneous was the independent political

60. LAURA BENY, A COMPARATIVE EMPIRICAL INVESTIGATION OF AGENCY AND MARKET ThEORIES OF INSIDER TRADING 16 (Harvard Law Sch., John M. Olin Discussion Paper Series, Working Paper No. 264, 1999), available at http://papers.ssm.com/paper.taf?abstract_id=193070.

61. Raghuram G. Rajan \& Luigi Zingales, The Great Reversals: The Politics of FinANCIAL DEVELOPMENT IN THE 20TH CENTURY 31-35 (Nat'l Bureau of Econ. Research, Working Paper No. 8178, 2001), available at http://www.nber.org/papers/w8178.

62. Id. at 33 .

63. Id. at 33-34. 
decision to privatize formerly state-owned industries. Mass privatization deepened securities markets across Europe and thereby created a constituency that came to desire fairer rules. That constituency is now beginning to pressure for legal changes.

Such a sequence seems predictable. Legal changes may have to await the appearance of a constituency to lobby for them. For example, mass privatization came overnight to the Czech Republic, and its securities market soon crashed, at least in part because of the absence of investor protections. Only then, several years later, were statutory reforms adopted to protect minority shareholders. ${ }^{64}$ Pistor has generalized that the same responsive reaction of law to economic change has broadly characterized the adoption of common-law reforms by transitional economies. ${ }^{65}$

Thus, with the recent growth of European securities markets, a constituency for reform (or at least enhancement) of European securities regulation may soon coalesce. What would its objectives be? Once a truly pan-European securities market comes into existence, the next logical step would be the responsive creation of a European SEC to enforce a harmonized system of securities regulation. But such a step requires, first, the unequivocal emergence of a pan-European securities market that is supra-national in character and, second, public dissatisfaction with its performance. The history of the systems of securities regulation in both the United States and the United Kingdom, as next discussed, suggests that such a reform program may only succeed once it is scandal-driven. Neither the pan-European market nor the requisite scandals have arrived.

\section{F. The Status of the Insider-Dominated Firm}

While takeovers have come to Europe, securities markets have deepened, and securities regulation may toughen, these developments should not obscure the still-unchanged status of the insider-dominated firm. Even if ownership concentration has declined across Europe, the difference may be only marginal, as the average free float of German listed companies has been estimated at only thirty-two percent, and eighty-nine percent of all listed companies have a single shareholder controlling more than twentyfive percent of their equity. ${ }^{66}$ Although many of these holders seem prepared to sell once the German capital gains tax is eliminated on January 1,2002 , the critical question becomes to whom they will sell: to a single

64. For an overview of the Czech experience, see John C. Coffee, Jr., Privatization and Corporate Govemance: The Lessons from Securities Market Failure, 25 J. CORP. L. 1, 9-10 (1999).

65. See supra notes $25-28$ and accompanying text.

66. Swann, supra note 58. 
purchaser of a controlling block, or to the public market through a secondary offering?

Those who believe that path-dependent forces will limit corporate convergence and preclude the appearance of "Anglo-Saxon" style dispersed ownership make the powerful argument that blockholders will continue to find it more profitable to sell control to new controlling purchasers than to break up the controlling block through a secondary offering. ${ }^{67}$ Indeed, precisely this pattern of controlling blocks remaining intact after an initial public offering has long been observed in Scandinavia. ${ }^{68}$ But, as discussed below, that pattern can change, and did so relatively quickly in both the United States and the United Kingdom.

\section{WHEN DOES SEPARATION OF OWNERSHIP AND CONTROL ARISE? A HISTORICAL PERSPECTIVE}

Most of the participants in the recent debate over corporate convergence have implicitly agreed on one (and possibly only one) theme: Deep, liquid securities markets arise only under special conditions. LLS\&V have emphasized the legal backdrop: Dispersed ownership is possible in their view only when the legal system provides adequate protection for minority shareholders. While stressing a path-dependency perspective, Professor Bebchuk has formulated a model that essentially states the reverse side of this coin: When the private benefits of control are high, dispersed share ownership will be a transient state, and controlling blockholders will eventually reappear. ${ }^{69}$ In such an environment, leaving control up for grabs would, he argues, only attract attempts by rivals to seize control and extract the private benefits of control. Hence, the firm's initial owners will not find it in their financial interest to sell a potentially controlling block of shares to the market, but will instead sell only to another incoming controlling blockholder, who will pay more because it can enjoy the private benefits of control. Finally, Professor Roe's view that the separation of ownership and control arises only when certain political preconditions are satisfied also implies that the evolution of deep and liquid securities markets is an exceptional event. In common, all these theories suggest that liquid securities market should not naturally evolve, absent the prior satisfaction of special legal or political preconditions.

Yet modern history seemingly supplies two counterexamples. Beginning in the last quarter of the nineteenth century and culminating no later than the 1930s in the United States and mid-century in the United

67. BEBCHUK, supra note 9.

68. HÖGFELDT \& HOLMÉN, supra note 11 , at 16.

69. BEBCHUK, supra note 9 , at 10-12. Obviously, the Bebchuk and LLS\&V positions are consistent, although each need not agree fully with the other. 
Kingdom, the largest private businesses in both the United States and the United Kingdom were converted into publicly owned corporations. ${ }^{70}$ In the process, control generally passed from families to the market.

Although both the timing and dynamics differed notably between these two countries, one common denominator was shared: Neither country provided strong legal protections for minority shareholders during this period. Moreover, at least during the late nineteenth century in the United States, the private benefits of control appeared very high-indeed to the point that the exploitation of minority shareholders resembled that which has occurred in Russia and other transitional economies over the last decade. Finally, although one can reasonably debate the precise timing of this transition, dispersed ownership persisted and grew in both countries during periods in which the local political environment arguably satisfied Professor Roe's definition of "social democracy," namely, the United States during the New Deal and the United Kingdom during the Labour governments of the 1940s and 1970s.

How then did these markets evolve? As next discussed, their experiences have less in common than their shared legal institutions or common cultural heritage might suggest. Instead, by very different means, both countries made it possible for corporate control to be held by the market - with the result that a company's initial owners could find it as profitable to sell control to the market as to an incoming controlling shareholder.

\section{A. The United States Experience}

The growth of public securities markets in the United States in the nineteenth century was driven by the enormous capital requirements of its railroads ${ }^{71}$ Railroad finance created a template. The financial infrastructure that their heavy demands for capital created was in turn utilized, with only

70. Brian Cheffins reports that, as late as the decade of the $1880 \mathrm{~s}$, only five to ten percent of Britain's largest business enterprises were incorporated, and "barely sixty domestic" companies had shares quoted on the LSE. CHEFFINS, supra note 20, at 15. Yet by 1907 , almost 600 industrial and commercial companies were quoted on the LSE. Id. at 16. Clearly, this amounts to a rapid and significant transition.

In the United States, the pace of this transition was even faster. In the period after the Civil War, U.S. financial markets were clearly less developed than those in London. Yet by 1913, the Pennsylvania Railroad had 86,804 shareholders holding its various classes of stock, the American Telephone \& Telegraph Company had 53,737 shareholders, and U.S. Steel, founded in 1901, had 44,398 common shareholders and 77,420 persons holding its preferred stock. R.C. MICHIE, THE LONDON AND NEW YORK STOCK EXCHANGES, 1850-1914, at 222-23 (1987). The financial network that created such a dispersed structure of share ownership in a few short decades is obviously worthy of serious study.

71. See Vincent P. Carosso. Investment Banking in AmeriCa 29 (1970) (noting that between 1870 and 1900 railroad "carriers were the largest corporate seekers of funds in the capital markets . . . and as such were the investment bankers' principal customers"). 
modest adjustments, to serve the similar financial needs of the steel, automobile, and telephone industries in the early twentieth century. Because the greater geographic distances to be connected in the United States implied that the capital costs were necessarily higher than in Europe, financing the railroad industry in the United States necessarily required the infusion of foreign capital. An estimated forty percent of this capital came from Europe, ${ }^{72}$ most of it funneled through London, which had already developed an expertise in international finance. ${ }^{73}$ This constantly increasing demand for capital and the reliance on foreign investors in turn produced two basic innovations that appeared in late nineteenth-century America in order to maximize the reputational capital underlying major stock issuances: (1) a corporate governance system in which investment bankers, originally protecting foreign investors, took seats on the issuer's board both to monitor management and to protect public investors from predatory raiders seeking to acquire control by stealth; and (2) the growth of selfregulation through stock exchange rules.

\section{The Role of Investment Bankers}

The financial infrastructure that arose in the second half of the nineteenth century in the United States was designed to satisfy relatively sophisticated investors in countries that were at the time more financially developed. The first generation of the new American investment bankers consisted in essence of bond salesmen to Europe-August Belmont was widely known as the Rothschilds' agent in the United States, and even J.P. Morgan himself was the American representative of an Anglo-American investment bank founded by his father with British investment bankers. ${ }^{74}$ These firms grew to dominance based on their ability to recruit foreign capital. $^{75}$

72. AlFred D. Chandler, JR., SCALE AND SCOPE: THE DYNAMiCS OF INDUSTRIAL Capitalism (1990); Saul Engelbourg \& LeONARD Bushkoff, THE MaN Who Found THE MONEY (1996). Between 1870 and 1900, "foreign investment in the United States more than doubled, increasing from approximately $\$ 1.4$ billion to $\$ 3.3$ billion." CAROSSO, supra note 71 , at 30.

73. See Ranald C. MiChie, The City of London 72-79, 109-11 (1992). Professor Cheffins notes that prior to World War I, British companies accounted for only "one-third of the funds raised on London's Stock Exchange." CHEFFINS, supra note 20, at 16. Hence, London was a financial market accustomed to exporting its capital abroad, particularly to Commonwealth countries and projects.

74. VinCENT C. CARosso, The MORgans (1987). For a discussion of August Belmont's role as the American agent of the Rothschilds, see CAROSSO, supra note 71, at 9-10.

75. Many of these firms, including Drexel, Morgan \& Co. and J.W. Seligman, were founded as private unincorporated banks in the $1860 \mathrm{~s}$. The characteristic that "distinguished these firms ... was their ability to recruit foreign capital." CAROSSO, supra note 71, at 30. For example, one measure of this dependence on foreign capital is the fact that, as late as 1913. eighteen percent of the stock of U.S. Steel, a firm founded by J.P. Morgan \& Co., was still owned by foreign investors. See MICHIE, supra note 70, at 56 . It seems likely that higher percentages of 
As elsewhere, the financial institutions that arose in the United States were primarily engaged in the marketing of debt securities. Expanding into equity securities was essentially equivalent to an established merchant adding an additional product line; both the merchant and the investment banker carried their reputational capital with them into the new business. This extension into equity securities probably occurred earlier in the United States because of the highly leveraged status of U.S. railroads. Inevitably, there are limits on the degree of leverage that any business firm can tolerate, and the greater capital needs of U.S. railroads thus implied that public equity issuances were necessary. In consequence, public equity markets developed earlier in the United States than elsewhere, even though the overall U.S. securities market was substantially smaller than the English market.

Formal corporate governance in these early railroad corporations did little to protect minority shareholders. Not only did control groups quickly form, but in some cases the objective of these blockholders was primarily to manipulate the stock price of their corporation. The story of the epic battle for control of the Erie Railroad - the "Scarlet Lady of Wall Street" between Commodore Vanderbilt, on one side, and Jay Gould and Daniel Drew, the leading stock manipulators of the era, on the other, has been told many times, ${ }^{76}$ but it deserves further consideration in light of the recent debates over comparative corporate governance. At the high point of the "Erie War" in the late 1860s, the Gould/Drew faction, which controlled the board, essentially prevented Commodore Vanderbilt from buying control of Erie in the open market by selling convertible bonds at heavily discounted prices to their allies, who would convert the bonds into stock in order to dilute Vanderbilt's voting power. Although not as elegant a takeover defense as the poison pill of the late twentieth century, this tactic worked very effectively. Even though Vanderbilt secured judicial injunctions against this tactic (apparently by bribing judges), they were ignored by the Erie control group, who secured rival injunctions from the judges that they bribed. Ultimately, Gould bribed enough members of the New York State Legislature to obtain passage of legislation that legitimized his tactics.

What was the lesson here? Essentially, the Erie control battle illustrated the manner in which regulatory arbitrage, carried to the extreme, could nullify minority legal protections. In the absence of any federal regulatory

stock in the largest U.S. corporations would have been held by foreign investors as of the end of the nineteenth century and that their investment decisions would have been coordinated, or at least strongly influenced, by their American investment bankers.

76. For standard accounts, see JOHN STEELE GORDON, THE SCARLET WOMAN OF WALL STREET (1988); and JULIUS GRODINSKY, JAY GOULD $1867-1892$ (1957). For a recent and highly relevant review of Gould's manipulative schemes from a corporate law perspective, see Edward B. Rock, Encountering the Scarlet Woman of Wall Street: Speculative Comments at the End of the Century, 2 THEORETICAL INQUIRIES L. 237 (2001). 
authority, the contending sides could move from jurisdiction to jurisdiction, seducing courts and legislatures. Even if the Erie battle was an exceptional case, it was heavily publicized and presented by at least one prominent contemporary commentator as representative. ${ }^{77}$ In less epic battles, the parties probably could not afford the massive transaction costs of corruption on the Erie scale, but the real point is that investors were vulnerable less because of the substantive inadequacy of American corporate law itself than because of the lack of enforcement mechanisms and the prospect of corruption. In truth, substantive corporate law in the United States during this era was arguably favorable to the minority shareholder. Most state statutes restricted the issuance of "watered" stock, the derivative suit had been recognized by the Supreme Court as a legal mechanism to protect minority shareholders, and the law of fiduciary duties generally required any corporate official who engaged in a self-dealing transaction with his firm to prove its "intrinsic fairness." ${ }^{78}$ But once the investor had committed his capital, he might discover that the corporation had migrated to another, more permissive jurisdiction or that its founders had amended its certificate of incorporation or caused the legislature to amend the law to give them greater freedom to exploit the public investor. ${ }^{79}$ Or, a judge would simply be bribed to accept some pretext for clearly predatory misbehavior. Because of these risks, some prominent underwriters (including Kuhn, Loeb) refused until the very end of the century to underwrite the common stock of industrial corporations. ${ }^{80}$

The investor who was defrauded in a securities transaction did have legal remedies against the promoters and managers of a company whose stock price had been inflated. By the middle of the nineteenth century, the American case law had established that a cause of action for fraud could be pled "where stock had been purchased in reliance on knowing misrepresentations by the issuer's agents as to the stock's value." ${ }^{81}$ Both in

77. Charles Francis Adams's famous article, A Chapter of Erie, focused on financial chicanery at the Erie Railroad and was probably the first true "muckraking" article, one that founded a literary genre in the late nineteenth and early twentieth centuries. Charles Francis Adams, A Chapter of Erie, 109 N. AM. Rev. 30 (1869). Given Adams's status as a son and grandson of American presidents, his attack naturally had credibility and would have influenced European readers. Thus, it seems fair to conclude that Europeans would have perceived themselves to be exposed as minority investors in U.S. companies at this time.

78. Later, many of these rules were relaxed. For a review of American corporate law at this late nineteenth-century stage, see LAWRENCE M. FRIEDMAN, A HISTORY OF AMERICAN LAW 446-63 (1973). Harold Marsh has also surveyed the status of the officer's and director's fiduciary duty to the corporation during this era and concluded that strong prophylactic rules against selfdealing existed. See Harold Marsh, Jr., Are Directors Trustees?, 22 BuS. LAW. 35 (1966).

79. FRIEDMAN, supra note 78, at 457-59.

80. See CAROSSO, supra note 71, at 43-44 (noting that Jacob Schiff of Kuhn, Loeb and others considered such investments to be of dubious value, principally because of the inadequate disclosures made by these corporations).

81. StUART BANNER, ANGLO-AMERICAN SECURITIES REgulation 237 (1998). 
the United Kingdom and the United States, courts had by mid-century also extended fraud liability "to misrepresentations not made specifically to the plaintiffs," but on which they had "relied to their detriment." ${ }^{82}$ New York had even criminalized the fraudulent issuance of stock. ${ }^{83}$ But before these legal developments can be asserted to supply the legal preconditions to the appearance of liquid securities markets in the United States and the United Kingdom, their limitations need to be recognized. First, the law of fraud as of this time applied only to affirmative misrepresentations, not to omissions, and imposed no duty on the seller to disclose information in its possession. ${ }^{84}$ Nor could plaintiff shareholders join together to file a class action, which had not yet developed in the United States and which remains largely unknown today in the United Kingdom. Hence, given the costs of litigation, the fraudulent promoter probably faced liability as a practical matter only to its larger customers. Next, because the United States was a federal system, the enforceability of a judgment against a defendant who had fled the jurisdiction remained a major problem. Finally, there was the problem of judicial corruption. In New York, the home of most securities transactions, many of the most notorious stock promoters, such as Jay Gould, were closely associated with Tammany Hall, the Democratic political machine that selected and often controlled local judges.

Given this uninviting legal environment, which would particularly deter foreign investors who could not easily conduct litigation from across an ocean, investment bankers hoping to interest such investors in the equity securities of U.S. corporations had to find some means by which these corporations and their entrepreneurs could credibly bond their promises. Litigation was simply not the answer for the foreign investor. Although foreign investors might buy debt and equity securities on the reputational capital of merchant bankers like J.P. Morgan, this reliance implied in turn that these agents had to develop a governance structure that enabled them to fulfill their representations to their clients that their investments were safe and sound.

One means to this end was pioneered by J.P. Morgan \& Co., namely, placing a partner of the firm on the client's board. Up until World War I, the American investment banking industry was extremely concentrated, and any flotation of more than $\$ 10$ million invariably was underwritten by one of six firms, of which the largest was J.P. Morgan \& $\mathrm{Co}^{85}$ Given their market power and the desires of distant investors for a "hands on" representative protecting their interests, it became common in the United States (but much less so in the United Kingdom) for the investment banker

82. Id. at 241

83. Id. at 242 .

84. Id. at 243.

85. MiCHIE, supra note 70 , at 226-27. 
to place one or more representatives on the issuer's board. During the last two decades of the nineteenth century, virtually every major U.S. railroad developed close ties with one or more U.S. investment banking firms, and the practice of partners from investment banks and officers of commercial banks going on the railroad's board became institutionalized. ${ }^{86}$

Recent research by financial economists suggests that these practices were both widespread and created value for investors. One survey of just the financial industry has found that during this period J.P. Morgan \& Co. held twenty-three directorships in just thirteen banks; First National Bank, which worked closely with J.P. Morgan, held fourteen directorships in other banks; and National City Bank held thirty-two such positions in sixteen banks and trust companies. ${ }^{87}$ More importantly, Professor Bradford De Long has assembled evidence suggesting that the presence of a J.P. Morgan $\&$ Co. representative on an issuer's board of directors added approximately thirty percent to the value of the firm's common stock equity. ${ }^{88}$

But why? Financial economists have theorized that such a representative enabled bankers to monitor the firm's mangers and investment projects, replacing those managers that were substandard and rejecting unpromising investment projects. ${ }^{89}$ Perhaps this sometimes happened. Still, the problem with this simple agency cost story is that investment bankers have generally not been viewed as activists in corporate governance, in part because any agent, including an investment banker, who intervenes aggressively in the principal's business risks losing the client. An alternative partial explanation is that investment bankers on the boards of competing firms sometimes served as a mechanism for price collusion (as reformers in the Progressive Era clearly believed).

A simpler and nonexclusive hypothesis may contribute a better explanation: The fundamental agency problem facing public investors in this era was not that their managers would expropriate wealth, but that incoming controlling shareholders would. ${ }^{90}$ In a world of still relatively concentrated ownership, shareholders could control managers, but were exposed to any shareholder who achieved majority control. Hence, the

86. CAROSSO, supra note 71, at 32-33. It should be noted that one firm (Kuhn, Loeb \& Co.) characteristically did not place its representatives on the issuer's board. It was seemingly the exception that proved the rule, but it may have limited its clientele to firms that found other means by which to bond their commitments to investors.

87. Carlos D. Ramirez, Did J.P. Morgan's Men Add Liquidity? Corporate Investment, Cash Flow, and Financial Structure at the Turn of the Twentieth Century, 50 J. FIN. 661, 665 (1995).

88. J. Bradford De Long, Did J.P. Morgan's Men Add Value? An Economist's Perspective on Financial Capitalism, in INSIDE THE BUSINESS ENTERPRISE 205 (Peter Temin ed., 1991).

89. See id.

90. A single-minded focus on managerial expropriation is probably a legacy of Berle and Means's continuing influence. More recent scholars have argued, however, that investors are more exposed to expropriation by controlling shareholders. E.g., Andrei Shleifer \& Robert W. Vishny, A Survey of Corporate Governance, 52 J. FiN. 737 (1997). 
presence of a major investment banking firm on the corporation's board offered mutual advantages both to the minority investors and to the corporate management by protecting both from the prospect of a stealth attack by a corporate raider seeking to acquire control without paying a control premium. That is, while the presence of the investment banker may have also reduced agency costs or prevented "disastrous" price wars, the greater problem at the end of the nineteenth century was the instability of control and the relative inability of public investors to demand and receive a control premium for its transfer. Takeover raids occurred in the nineteenth century, ${ }^{91}$ but lacked the visibility of the later tender offer wars of the late twentieth century, precisely because the control seeker did not need to offer publicly to purchase a majority of the issuer's shares at a premium, but instead could assemble a controlling block at low cost by buying secretly in the open market. Because the major investment banking firms were positioned close to the market, they were logically in a position to detect such a raid and to finance a counterbid or design appropriate defensive measures. More importantly, they also spoke for the foreign investors, who were likely to act collectively based on the advice of their American agent.

This explanation of the investment banker's role as a protector of the public shareholder from attempts by speculators to steal a firm's control premium is not merely theoretical, but can be corroborated with actual examples. In the late 1880 s, Kidder Peabody, in conjunction with Barings, a British merchant bank, took control of the affairs of the Santa Fe Railroad, which was then teetering on the brink of insolvency, placing three partners on its board. Kidder Peabody did not, however, hold a large equity stake itself, so it devised a complicated voting trust strategy explicitly to defeat a perceived control threat from Jay Gould ${ }^{92}$ Indeed, even the redoubtable J.P. Morgan first made his reputation as a railroad financier when, as a young man in 1869, he coordinated the efforts of the Albany \& Susquehanna Railroad to fight off the attempt of Jay Gould and Jim Fisk to take control of that railroad in a battle popularly known as the Susquehanna War. ${ }^{93}$ After each side obtained rival injunctions and a pitched battle between small armies hired by both sides proved inconclusive, Morgan resolved matters by negotiating a merger of the Albany \& Susquehanna Railroad into the larger Delaware \& Hudson, thereby putting the target beyond Gould's reach. Morgan then went on the board of the new entity. However, neither

91. See Walter Werner \& Steven T. Smith, Wall STREet 133-40 (1991). Jay Gould, in particular, was noted for conducting proxy fights after buying a substantial block of stock. Often, these contests produced a "greenmail" payment to him, or he would short the stock before announcing the end of his proxy contest. MAURY KLEIN, THE LIFE AND LEGEND OF JAY GOULD 197-205, 277-80 (1986).

92. See CAROSSO, supra note 71 , at 36-37.

93. CAROSSO, supra note 74, at 121-22. For a fuller account, see RON CHERNOW, THE HOUSE OF MORGAN 31-32 (1990). 
Morgan nor other investment bankers in similar battles during this era sought to take personal control of the corporations they defended. Their role was rather that of an agent protecting their investors. "Board membership," as Ron Chernow has generalized, "[became] a warning flag to ... [others] to stay away from a captive company." 94

As a result, to the extent that public shareholders received protection from predatory raiders seeking to acquire control without paying a premium, public shareholders could afford to pay a higher premium for shares. Correspondingly, the firm's founders benefited from such a relationship because they now could, in effect, sell control to the market, rather than having to retain a control block until a majority purchaser appeared. Moreover, to the extent that the firm's founders remained active in management, they also gained protection from a subsequent disruptive hostile takeover by a robber baron, which would typically have been a coercive partial bid made without a premium.

From a comparative perspective, the most interesting aspect of this hypothesis is that it helps explain why control was not transferred to the market by similar means across Europe. First, financial institutions closely corresponding to the House of Morgan either did not exist outside the United States, or simply did not wish to accept the risks inherent in underwriting equity securities. Partly, this was because J.P. Morgan \& Co. and its very few peers were highly capitalized, specialized institutions that, from the 1890s on, focused on basically two activities: (1) underwriting very large issuances of securities, and (2) arranging mergers and acquisitions. The leading English merchant banks were unwilling (until later in the twentieth century) to engage in Morgan's high-risk underwriting activities, which typically involved buying the entire issue from the company and then reselling it to the market. Instead, English merchant banks largely left this realm to more marginal players, known as "stock promoters," who acted only as agents. ${ }^{95}$ For reasons discussed later, English underwriters tended to be smaller in size and thus less able to take such risks. In addition, they did not develop in an equivalent environment in which their client industries had a constantly expanding need for capital that required ever larger flotations.

Second, investment bankers in the United Kingdom did not represent the same cohesive and substantial fraction of the public shareholders as did American investment bankers serving as agents for the foreign investors in U.S. securities. Not only did foreign investors represent a smaller proportion of the United Kingdom equity market, but U.K. investment

94. CHERNOW, supra note 93, at 32.

95. According to some authorities, British merchant banks did not become interested or heavily involved in underwriting domestic new issues until the 1920s. See 3 David KYNASTON, THE CITY OF LONDON 135-36 (1999). 
banks, being considerably smaller, would typically represent fewer domestic investors as well. ${ }^{96}$

Finally, a third factor that played a role in both the growth of investment banking firms and the rapid appearance of dispersed ownership in the decades just before 1900 was the first great merger wave of 1895 to 1903. Interestingly, the greater scale of this consolidation movement in the United States, in contrast to that in the United Kingdom, illustrates the significance of legal differences. Historians believe that the turn-of-thecentury merger wave was driven in large part by the passage of the Sherman Antitrust Act of $1890 .{ }^{97}$ That Act prohibited price-fixing and collusion among competitors, thereby outlawing the cartel-like structure that characterized many American industries. But if cartels of conspiring firms were forbidden, competitors could instead employ mergers to create monopolies -at least until this was later also prohibited. In any event, the Sherman Act triggered a wave of horizontal mergers among competitors that, in the process, also diluted existing blockholders and thereby created dispersed ownership. The classic example was the consolidation of some eight competing steel companies into a new firm, U.S. Steel, in 1901. The transaction was engineered by J.P. Morgan and created the largest business corporation in the world. A transaction on such a scale inherently created dispersed ownership, even if each of the corporate participants previously had concentrated ownership, and it also produced a new firm with so heightened a capitalization that it was simply beyond the ambitions of any potential raider, thus making dispersed ownership stable.

In contrast to U.S. courts, British courts appear to have been significantly less aggressive in restricting cartels or prohibiting horizontal price-fixing agreements during this period. Hence, there was a weaker incentive to merge, and larger scale business entities emerged more slowly, while family capitalism survived longer in the United Kingdom. ${ }^{98}$ For

96. With entry to the LSE being relatively easy, "there was . . little incentive for the creation of large firms." MiCHIE, supra note 70, at 256. In contrast, because membership in the NYSE was fixed, brokerage firms with a seat on the NYSE grew both in order to exploit their monopoly position and to realize economies of scale that could not be realized in London as a result of restrictions on outside financing and prohibitions on partners in brokerage firms conducting other business. See infra notes 105-106 and accompanying text. In short, as the demand for brokerage services increased, the size of firms grew in New York, while the number of firms increased in London. Id. at 256.

97. Alfred D. Chandler, Jr., and Leslie Hannah, both noted business historians, have argued that differing policies toward cartels in the United States and Britain help explain the different scale of the turn-of-the-century merger wave in both nations. CHANDLER, supra note 72 , at 28894: Lcslie Hannah, Mergers, Cartels and Concentration: Legal Factors in the U.S. and European Experience, in LAW AND FORMATION OF THE BIG ENTERPRISES IN THE 19TH AND EARLY 20TH CENTURIES 306, 306-15 (Norbert Horn \& Jurgen Kocka eds., 1979).

98. See Tony Freyer, Legal Restraints on Economic Coordination: Antitrust in Great Britain and the Americas, 1880-1920, in COORDINATION AND INFORMATION 183, 183-202 (Naomi R. Lamoreaux \& Daniel M.G. Raff eds., 1995). 
immediate purposes, however, the relevant point is that the lesser the incentive to merge, the slower the movement toward dispersed ownership. Hence, we encounter an additional reason why dispersed ownership arrived earlier in the United States, and it has little to do with the relative legal rights of minority shareholders.

\section{The New York Stock Exchange as Guardian of the Public Investor}

The active role played by the New York Stock Exchange (NYSE) in American corporate governance has been noted by others, ${ }^{99}$ but its pathdependent history has escaped serious attention. Three points merit special emphasis at the outset: First, exchange activism was not the norm elsewhere, and the NYSE's active efforts contrast sharply with the passivity of the London Stock Exchange (LSE) and that of the European bourses generally. Second, the NYSE did not possess a de facto monopoly position in trading equity securities as of the late nineteenth century. Predominant as it may have been in debt securities, it ranked well behind other exchanges in the trading of equity securities throughout the late nineteenth century. Prior to 1900, "the Boston Stock Exchange was the principal market for industrial securities," 100 and two Boston investment banking firms-Kidder Peabody and Lee, Higginson-were the dominant underwriters of equity securities. ${ }^{101}$ Third, that the NYSE uniquely became an activist on corporate governance issues and ultimately the champion of the public investor seems directly attributable to its organizational structure and its competitive position.

This last point comes most clearly into focus when we compare the NYSE with the LSE. Between 1850 and 1905, the membership of the LSE rose from 864 to $5567 .{ }^{102}$ In sharp contrast, the membership of the NYSE

99. Indeed, the NYSE's leadership role was recognized from early in the last century. Prior to the passage of the federal securities laws in the 1930s, "even the most unrelenting critics of corporate finance lauded the Exchange's listing requirements." JOEL SELIGMAN, THE TransFormation OF WALL STREeT 46 (1982). Dean Seligman notes that the NYSE's listing requirements were "far more precise than any found in the blue sky laws" and became the model for the subsequently-enacted Schedule A to the Securities Act of 1933. Id. Probably the most outspoken critic of Wall Street practices prior to the stock market crash of 1929 was Harvard Professor William Z. Ripley. But even he described the NYSE as "the leading influence in the promotion of adequate corporate disclosure." WILLIAM Z. RJPLEY, MAIN STREET AND WALL STREET 210, 213-14 (1927).

100. CAROSSO, supra note 71 , at 44.

101. Id. The Boston Stock Exchange's early predominance came from its natural leadership position in the underwriting of the New England textile mills; also, some early railroad underwritings - such as those of the Atichison, Topeka and Santa Fe-were effected exclusively in New England, with the railroad's stock being listed only on the Boston Stock Exchange. Id. at 34.

102. MichiE, supra note 70 , at 252 . One reason that admission to the LSE was open was that the stockholders of the LSE were distinct from the LSE's member brokers, and they profited from 
stayed constant between 1879 and 1914 at $1100 .{ }^{103}$ While admission to the LSE was "cheap and easy," ${ }^{104}$ entry to the NYSE could only be gained by buying the seat of an existing member. The closed structure of the NYSE gave its members very different incentives, particularly regarding regulation, from those of members of an "open" exchange, such as the LSE. First, the NYSE's restrictions on membership encouraged the growth of large, diversified financial services firms (such as J.P. Morgan \& Co.), while the typical British brokerage firm remained small in size, with typically only six to seven partners. Second, having paid more to join the NYSE and holding a transferable asset with a substantial market value, a NYSE member had a stronger reason to favor self-regulation that protected the value of its seat; also, larger firms probably enjoyed greater reputational capital and thus had a greater interest in protecting it. Third, the small size of the NYSE implied logistical constraints on the ability of its membership to trade all securities for which a public market might have been made. Necessarily, the NYSE's decision to limit its membership fragmented the United States equity market, creating a high-quality tier and a lower-quality tier that traded elsewhere on an over-the-counter basis. Further encouraging larger and better capitalized firms on the NYSE was another difference in the two exchanges' organizational rules: NYSE member firms could raise capital from outsiders-known as "special partners" - and not all partners in a firm were required to be members of the exchange. ${ }^{105}$ In contrast, the LSE required all partners in a firm to be members of the exchange and further prohibited every member from engaging in any other business. ${ }^{106}$ The relative freedom enjoyed by NYSE firms in obtaining outside capital resulted not only in larger size, but also in a greater ability to engage in higher-risk underwriting activities.

Another key difference between the two exchanges was their positions on the question of competitive versus fixed brokerage commissions. Throughout the late nineteenth century, the NYSE had fixed brokerage commissions, while the LSE did not (at least until just before World War I). Again, this difference reflected the cartel-like organization of the NYSE in comparison to the open market character of the LSE. Because fixed commissions raised the cost of trading, this practice drove trading in lowervolume and lower-price stocks off the NYSE. Competitors could, and did,

the admission fees paid by new brokers. Thus, the LSE's owners wished to maximize admission fees, while its brokers might have preferred to maximize brokerage commissions.

103. Id. at 253. The only increase between 1868 and 1914 came in 1879 when the NYSE added forty seats. Id.

104. Ranald C. Michie, Different in Name Only?: The London Stock Exchange and Foreign Bourses, c. 1850-1914, in THE DEVELOPMENT OF LONDON AS A FINANCIAL CENTRE (Ranald C. Michie ed., 2000).

105. MiCHIE, supra note 70, at 256-57.

106. Id. 
win the low-volume business from the NYSE. But the business that migrated elsewhere consisted disproportionately of lower-price and higherrisk stocks. ${ }^{107}$ Consequently, the NYSE quickly made a virtue of this inevitability, arguing that the low-price or low-volume stocks that migrated to other trading venues were unsuitable for the public customer. In combination with the fact that the NYSE's small and fixed number of member firms could not logistically handle the trading in all firms that might wish to list on the NYSE, fixed-price commissions led the NYSE to define its role narrowly and limit itself to a high-volume, high-quality business. In short, for economic reasons, the NYSE recognized by the midnineteenth century that it made sense for it to pursue a strategy of exclusivity. ${ }^{108}$ Accordingly, it would deliberately list and trade only large issuers whose high-volume trading could support minimum commissions. Thus, as of 1900, the LSE listed 3631 different issuers of securities, while the NYSE listed only $1157 .{ }^{109}$ This difference was largely the NYSE's choice, and the product of its decision to reject most listing applications.

A final factor that reinforced the NYSE's preference for listing only large, high-quality issuers was its fear that listing high-volatility stocks would invite predictable insolvencies among its members. Such insolvencies could expose the broker's trading partners to similar failure. Repeatedly, in the late nineteenth century, financial panics had caused NYSE member firms to fail and had imposed significant liabilities on the failed firm's trading partners. Because the NYSE, as an essentially closed cartel, had far fewer members than the LSE, it also had more to fear from the failure of any member firm. Hence, to minimize the risk of member failure, the NYSE was far more conservative (and risk averse) about the securities that it would list. For example, it refused to list mining or petroleum companies during this period, because such securities were thought to be especially volatile. ${ }^{110}$ The rationale here was less a paternalistic concern for the investor than the fear that mining and petroleum stocks typically experienced volatile price movements (based on discoveries or rumors of discoveries), and a broker holding such stocks was

107. The NYSE's one-eighth percent commission "was considered high by contemporaries, and it encouraged many interested parties to deal with outside brokers or members of other exchanges, where the rates were lower." Id. at 259. Moreover, because the rate was charged on par value, it was "particularly onerous on shares with low real value, such as many mining and later industrial securities, and so discouraged trading in these on the New York Stock Exchange." Id. Typically, lower-price stocks ("penny stocks" in the contemporary parlance) were riskier and more volatile. In the late nineteenth century, some mining and industrial companies used such "small-denomination securities to attract investors." $1 d$. at 199. But because the NYSE focused on the needs of "substantial investor[s]," it did not attempt to compete for this business. Id. At least during the late nineteenth century, however, these more speculative issues were driven off the NYSE less by quality controls than by the impact of the NYSE's high-cost commission structure.

108. ld. at 272 .

109. Id. at 264 .

110. Id. at 198,273 . 
exposed to greater risk in a financial panic. The consequence was that to be listed on the NYSE, a company as of 1900 had to be at least five times larger than its counterpart on the LSE."'

From these differences in the organizational structure of the NYSE and the LSE, very different approaches toward self-regulation quickly emerged. From well before 1900, the NYSE saw itself as the guardian of the financial quality of the issuers listed on it. Perhaps it imposed high listing standards for its own self-interested reasons, but it clearly did regularly reject issuer applications, either because the issuer lacked an adequate earnings track record, had insufficient assets, or was in a high-risk industry. In so doing, the NYSE was also able to distinguish itself from its American competitors and present an image to investors as the most reputable exchange. Indeed, under the NYSE's prodding, the standard of disclosure for public companies was significantly enhanced, and some financial historians date the advent of modern financial reporting from 1900, not from 1933, when the federal securities laws were first adopted. ${ }^{112}$ In contrast, the LSE made no similar effort to police its securities market, at least until the period after World War $1 .{ }^{113}$ The LSE's more laissez-faire approach probably reflected the fact that it faced less competition and that its stockholders profited directly from the admission of additional brokers and issuers.

The NYSE's acceptance of the role of guardian of the public investor probably climaxed in the 1920 s with its express, if reluctant, decision to protect the voting rights of the dispersed shareholder by refusing to list nonvoting common stock. Prior to 1900 , corporate shares, both common and preferred, typically carried equal voting rights, but beginning shortly after 1900, investment bankers began to develop devices to centralize voting control in a small percentage of the outstanding equity shares, which were typically held by investment banking firms. ${ }^{14}{ }^{4} \mathrm{~A}$ number of devices, including dual class stock, voting trusts, and pyramid holding company structures, came into increasingly common use. Indeed, when Berle and Means surveyed the American corporate scene in 1930, they found that, in twenty-one percent of the 200 largest corporations, ultimate control was attributable to a legal device. ${ }^{115}$ Matters came to a head in 1925 , when a few leading corporations made large offerings of nonvoting common stock, with

111. Id. at 272.

112. See David F. Hawkins, The Development of Modern Financial Reporting Practices Among American Manufacturing Corporations, in MANAGing Big Business 166, 166-67 (Richard S. Tedlow \& Richard R. John, Jr., eds., 1986).

113. Ranald C. Michie, The London Stock ExChance 115 (1999).

114. This observation was first made by contemporaneous observers who dated the transition to around 1903. See, e.g., W.H.S. Stevens, Stockholders' Voting Rights and the Centralization of Voting Control, 40 Q.J. ECON. 353, 355-56 (1926); W.H.S. Stevens, Voting Rights of Capita! Stock and Shareholders, 11 J. Bus. 311 (1938) (noting the trend away from equal voting rights).

115. ADOLF A. BERLE \& GARDINER C. MEANS, THE MODERn CORPORATION AND PRIVATE PROPERTY 109 (rev. ed. 1991). 
the consequence that investment banking firms, sometimes owning securities representing well under five percent of the firm's market capitalization, held majority voting control. ${ }^{116}$ A Harvard professor of political economy, William Ripley, made a highly critical speech, attacking this development as ensuring "banker control" of large corporations. The speech received wide press coverage, and the professor was ultimately invited to the White House to explain his concerns to an apparently sympathetic President Coolidge. ${ }^{117}$ Although the NYSE sought to keep a low profile throughout the controversy, it saw that nonvoting common stock had become an issue of broad public concern, and early in the following year, it adopted a policy not to list nonvoting common stock or companies that issued such a class of securities. ${ }^{118}$ Over time, this policy was broadened to require listed companies not to issue a block of stock carrying sufficient voting power to transfer control without an authorizing shareholder vote. ${ }^{119}$ As a result, without intending to champion any movement, the NYSE became identified with mandatory listing conditions that protected "shareholder democracy" and prevented the separation of cash flow rights from voting rights. In the wake of recent economic research finding that the separation of cash flow and voting rights has been the principal technique for expropriation from minority shareholders in Asia, ${ }^{120}$ the NYSE's 1926 reform may have had unrecognized significance, not because it barred nonvoting common stock, but because it grew into a normative principle that effectively barred voting trusts and dual class capitalizations from U.S. public markets. ${ }^{121}$

116. The best known incident involved a stock offering by Dodge Brothers, Inc., which, with a total market capitalization of $\$ 130$ million, was controlled by the investment banking firm of Dillon, Read \& Co. based on a less than $\$ 2.25$ million investment (or less than two percent of all capital invested in the firm). Joel Seligman, Equal Protection in Shareholder Voting Rights: The One Common Share, One Vote Controversy, 54 GEO. WASH. L. REV. 687, 694 (1986).

117. Id. at 694-96. The controversy surrounding the Dodge Brothers offering and the public outcry over "banker control" based on small minority stakes has been reviewed by numerous commentators. See JOSEPH A. LIVINGSTON, THE AMERICAN STOCKHOLDER 186-87 (1958); ROBERT SOBEL, THE BIG BOARD 236 (1965). Professor Ripley went on to generalize his views in a broader populist critique, which was one of the significant influences leading Congress to enact the federal securities laws. WiLliam Z. RIPLEY, MAIN STREET AND WALL STREET 86-87 (1927) (describing the Dodge offering).

118. LiVINGSTON, supra note 117, at 187; SOBEL, supra note 117, at 236; Seligman, supra note 116 , at 697 .

119. Seligman, supra note 116 , at 689 . The NYSE policy barred not only the issuance of a control block, but, as it came to be framed in a bright-line rule, any issuance of common stock carrying more than $18.5 \%$ of the firm's voting power without a prior shareholder vote. Id.

120. STIJN Claessens ET AL., ON EXPROPRIATION OF MiNORITY SHAREHOLders: EvIDENCE FROM EAST ASIA, (SSRN Elec. Library, Working Paper No. 202,390, 2000), available at http://papers.ssm.com/paper.taf?abstract_id=202390; STIN ClAESSENS ET AL., THE SEPARATION OF OWNERSHIP AND CONTROL IN EAST ASIAN CORPORATIONS (SSRN Elec. Library, Working Paper No. 206,448, 2000), available at http://papers.ssm.com/paper.taf? abstract_id=206448.

121. Ironically, economic analysis today regards the issuance of nonvoting common stock as essentially innocuous, as the purchasers will pay little for such a security and hence they risk little. 
The point of this story is not that the NYSE has always behaved as a public-regarding, altruistically motivated entity. Rather, it is that for a variety of path-dependent reasons, the NYSE organized itself as an exclusive, high-quality securities market that would list only securities that were suitable for the public investor-while the LSE did not. In the total absence of legal requirements, the NYSE imposed mandatory disclosure obligations on its listed firms and protected shareholder voting rights. Correspondingly, the larger size of U.S. brokerage firms, which again was originally attributable to differences in the organizational rules of the NYSE and the LSE, gave U.S. brokers greater ability to underwrite securities and to develop and pledge their reputational capital to their investor customers. These two developments-the development of a monitoring capacity by the NYSE and the bonding mechanisms first developed by U.S. underwriters to attract foreign capital-constitute the twin pillars that supported the development of a liquid equity securities market in the United States. Such a public market arose more quickly in the United States than in the United Kingdom. For example, by 1907 , one Wall Street firm already had 22,000 customers, ${ }^{122}$ indicating that it was providing services on a mass scale. Yet, the legal framework that today characterizes the United States securities markets did not arise until decades later.

\section{B. The British Experience}

In contrast to the high listing standards that the NYSE imposed by the late 1800 s, the LSE's basic policy was to list any security that was expected to generate business. ${ }^{123}$ Only in "rare cases, where something adverse was known about the security and the circumstances surrounding its issue," would a listing application be denied for reasons other than lack of trading interest. ${ }^{24}$ of course, this attitude reflected the natural attitude of an "open" exchange with broad membership: More listings implied more business, and the failure of an occasional brokerage firm (which were characteristically smaller in size) did not constitute as serious a threat to the LSE as it did to the NYSE-in part because the LSE had a considerably

More sinister in the view of most recent commentators is the issuance of a high-voting security after common stock has been sold to public investors, because this later issuance dilutes the voting power of outstanding shares. Ronald J. Gilson, Evaluating Dual Class Common Stock: The Relevance of Substitutes, 73 VA. L. REV. 807, 840-42 (1987); Jeffrey N. Gordon, Ties That Bond: Dual Class Common Stock and the Problem of Shareholder Choice, 76 CAL. L. REV. 3, 4 (1988). Yet, however myopic its original purpose, the NYSE's "one share, one vote" rules served to protect common shareholders from any significant dilution of their voting power.

122. MiCHIE, supra note 70 , at 228 .

123. MiCHIE, supra note 113 , at 96 .

124. Id. 
deeper capital base. ${ }^{125}$ Finally, stock issuances were typically arranged in the United Kingdom by stock promoters, not the largest merchant banks. These promoters often had unsavory reputations and little reputational capital to pledge. ${ }^{126}$

Given the LSE's laissez-faire approach and, indeed, its caveat emptor attitude, it is thus not surprising that the public equity market developed more slowly in the United Kingdom than in the United States. Exactly when dispersed ownership arrived in the United Kingdom is debatable. In 1936, the median proportion of the voting share held by the twenty largest shareholders in the eighty-two largest nonfinancial U.K. corporations was approximately $40 \%$ (whereas the same ownership level for U.S. corporations was then $28 \%$ ). ${ }^{127}$ Moreover, in $40 \%$ of U.K. companies, the twenty largest shareholders held a collective absolute majority. ${ }^{128}$ Thus, although share ownership may have been dispersed, the separation of ownership and control had not yet truly occurred. A parallel study based on 1977 data found that the largest twenty shareholders then held between $20 \%$ and $29 \%$ of the voting stock. ${ }^{129}$ Although such a block might still carry control, it is doubtful that the twenty largest shareholders were by this point truly a cohesive group, as institutional investors were now heavily represented in the top twenty. ${ }^{130}$ Hence, sometime between the late 1930 s and the mid-1970s, ownership and control probably separated in most U.K. companies. ${ }^{131}$

The deeper question is not when dispersed ownership arrived, but why it occurred. In the absence of high listing standards or underwriting practices that placed the reputational capital of credible financial intermediaries behind most offerings, why did public investors place trust and confidence in the United Kingdom market?

125. MiCHIE, supra note 70, at 272 (noting that the NYSE's capitalization was one-third that of the LSE).

126. For this common assessment, see W.A. THOMAS, THE FINANCE OF BRITISH INDUSTRY 23 (1978); and John Armstrong, The Rise and Fall of the Company Promoter and the Financing of British Industry, in CAPITALISM IN A MATURE ECONOMY 115, 130-31 (J.J. Van Helten \& Y. Cassis eds., 1990).

127. P. SARGANT FLORENCE, THE LOGIC OF BRITISH AND AMERICAN INDUSTRY 189 (1953).

128. Id.

129. John SCOTt, Capitalist Property and FinanCial POWER 95 (1986). For a review of this literature, see Bernard S. Black \& John C. Coffee, Jr., Hail Britannia?: Institutional Investor Behavior Under Limited Regulation, 92 MICH. L. REV. 1997, 2029-33 (1994).

130. Id. at 2030-31 (analyzing the list of twenty largest shareholders in Scott's study).

131. Cambridge University Professor Brian Cheffins opines that "[t]here is some evidence which suggests that the period prior to 1950 was pivotal." CHEFFINS, supra note 20, at 19 . While he is equivocal about 1950, he is more convinced that it arrived before 1970. Leslie Hannah, a British business historian, similarly concludes that the separation of ownership and control was established in Britain by the middle of the twentieth century. LESLIE HANNAH, THE RISE OF THE CORPORATE ECONOMY 90-91, 123-24 (2d ed. 1976); CHEFFINS, supra note 20, at 22. These dates precede the appearance of Margaret Thatcher on the political scene and suggest that dispersed ownership arrived during a social-democratic era in Britain. 
Several tentative hypotheses can be advanced. First, less effort may have been expended on self-regulation in the United Kingdom because judicial corruption and regulatory arbitrage posed less of a threat. In this light, self-regulation is an example of a functional substitute that arose at least in part to solve the problem of endemic judicial corruption in the United States during the late nineteenth century. Again, this is an illustration of functional convergence.

Second, the United Kingdom may have had a more cohesive business community than did the United States in this era, with either a stronger normative code or a perceived greater exposure to the loss of reputational capital based on any association with a securities scandal. Either factor could have restrained U.K. managers in the absence of law. Contemporary data show that the private benefits of control differ significantly among countries, even countries belonging to the same legal family. ${ }^{132}$ As of the late nineteenth century, there is every reason to believe that in the United Kingdom, the business community in general, and the securities industry in particular, was more socially stratified and class-bound than in the United States.

Finally, as next discussed, there were material differences between U.S. and U.K. law in this era, and British law did regulate securities offerings to a greater degree than did U.S. law, from as early as the 1860s. Thus, although U.S. institutions moved more quickly to adopt self-regulatory standards, British mandatory law regulating disclosure was enacted well in advance of similar developments in the United States. Different paths were followed at different speeds to an approximately equivalent end point. If one looks at the aggregate effect of mandatory law plus self-regulation in both countries, the level of shareholder protection was arguably similar in the United States and the United Kingdom up until the passage of the federal securities laws and the creation of the SEC in the United States in the mid-1930s. What Britain did by legislation, the United States did by self-regulation. It need not be claimed that the two countries had equivalent protections at equivalent times, but only that both satisfied the minimum standards necessary for dispersed ownership to result. That both could have reached this same level by different means is again an example of functional convergence.

The claim that U.K. law provided superior protections to minority investors may seem surprising and must be qualified, because only the disclosure provisions of U.K. law were more protective than the equivalent standards in the United States. Outside this context, the contrasts between

132. John C. Coffee, Jr., Do Norms Matter?: A Cross-Country Examination of the Private Benefits of Control, 149 U. PA. L. REV. (forthcoming 2001) (citing data showing cross-country disparities in the private benefits of control, including among countries within the common-law family). 
U.S. corporate law and British company law as of 1900 would seem to have largely favored the minority shareholders in the United States over their British counterparts. Basically, the United Kingdom shareholder had no appraisal right and only an ineffective derivative action remedy. Worse, the shareholder's rights were subject to the ability of a majority of the shareholders to ratify any conflict of interest transaction and thereby place it beyond judicial review. ${ }^{133}$ Worse yet, exculpatory provisions were permitted in the corporate charter that could cancel even the duty of loyalty. ${ }^{134}$ In short, U.K. corporate law had not yet comprehensively adopted the standards of minority protection that LLS\&V contemplate as the precondition for dispersed ownership.

Still, whatever the status of its substantive corporate law, Britain did lead the United States in its statutory regulation of disclosure to investors. ${ }^{135}$ A series of stock market scandals in the United Kingdom in the 1870s had led to two "public enquiries" by Parliament, but had not produced legislation. ${ }^{136}$ Then, in 1890 , at the very outset of the relevant transitional period for U.K. purposes, Parliament overruled a judicial decision that had narrowly construed the law of fraud by enacting legislation that permitted investors to recover damages if (1) they suffered loss by reason of an untrue statement in a prospectus, and (2) those responsible for its preparation could not prove that they had reasonable grounds to believe that the statement was true. ${ }^{137}$ Not until 1933 was U.S. law to reach a similarly pro-investor position when Congress enacted the Securities Act of 1933, which, in section 11, contains a similar standard for prospectuses that was in fact modeled after this 1890 statute. ${ }^{138}$ The Companies Act of 1900 supplemented this antifraud standard by specifying what the prospectus

133. For a review of U.K. law in this era, see BRIAN R. CHEFFINS, DoEs LAW MATTER?: THE SEPARATION OF OWNERSHIP AND CONTROL IN THE UNITED KINGDOM (ESRC Ctr. for Bus. Research, Univ. of Cambridge, Working Paper No. 172, 2000), available at http://papers.ssm.com/paper.taf?abstract_id $=245560$. For a notable case from the period upholding majority ratification of a self-dealing transaction, see North-West Transportation Co. v. Beatty, 12 App. Cas. 589 (P.C. 1887) (appeal taken from Ont.). 1997).

134. Paul L. Davies, Gower's PRINCiples Of MOdern COMPany Law 611-12 (6th ed.

135. The history of securities regulation in the United Kingdom dates back to 1844, when in the Companies Act of 1844, Parliament "enacted the first modern prospectus requirement." Louis Loss \& Joel Seligman, SeCurities Regulation 5 (3d ed. 1989). However, it was not until the Companies Act of 1867 that "the contents of the prospectus were in any way specified." Id. at 6 . In any event, these provisions were "easily evaded by exacting waivers from subscribers." Id. Thus, the risk of liability does not appear to have become real until the 1890 legislation. See infra note 137 and accompanying text. However, beginning with the report of the Lord Davey Committee in 1895, Parliament expressly rejected the norm of caveat emptor and in 1900 mandated in detail the specific contents of the prospectus used to sell securities. Id.

136. See MiCHIE, supra note 73, at 3 .

137. Directors' Liability Act, 1890,53 \& 54 Vict., c. 64 (overruling Derry v. Peak, 14 App. Cas. 337 (1889) (appeal taken from Eng.)).

138. LOSS \& SELIGMAN, supra note 135, at 6-8; Kilbride, The British Heritage of Securities Legislation in the United States, 17 Sw. L.J. 258 (1963). 
offering securities had to disclose. ${ }^{139}$ In 1907, the first step toward a mandatory continuing disclosure system was taken with legislation that required publication of an annual balance sheet. ${ }^{140}$ Legislation in 1908 addressed (albeit in a limited manner) abuses in the new issue market. ${ }^{141}$ Finally, in 1929, legislation obliged the issuer to provide an income statement and related data on current earnings. ${ }^{142}$ Rudimentary as these requirements may seem today, they were enacted well ahead of corresponding legislation in the United States, although they may have been slightly behind practices at the NYSE. As a generalization, then, the United Kingdom seems to have led the United States in the area of securities regulation, but lagged behind the United States in terms of minority protections in its substantive corporate law. Not until amendments to the Companies Act in 1948 were strong restrictions on self-dealing enacted.

Well before this point, however, the reluctance of the LSE to play any regulatory role in the protection of investors began to change, probably starting shortly after World War I. ${ }^{143}$ In 1921, it adopted its first regulations governing the rights of members to deal in or quote a security. ${ }^{144}$ During the years between the two world wars, the LSE's Share and Loan Department began to make inquiries before listing a company into the company's operations and the personnel connected with it. By the 1930s, the LSE's own disclosure requirements for listed companies were more extensive than those set forth in the United Kingdom's companies legislation. ${ }^{145}$ Still, the LSE did not become a de facto regulator in partnership with the state until after World War II.

The willingness of the LSE to assume a greater regulatory role appears to have been largely scandal-driven. Following a speculative boom in new issues in the 1920s, a major scandal shook the LSE in 1929, when a flamboyant promoter, Charles Hatry, was found to have fraudulently sold counterfeit shares in established companies, intending to buy them back before dividends were declared. ${ }^{146}$ The Hatry scandal produced little, if any, legislation, but it did force the LSE to accept some role as a guardian of issuer quality. ${ }^{147}$ The LSE became less willing to list what would today be called "penny stocks," or development-stage companies. By the 1950s, the LSE's listing rules had been tightened to require issuers to reveal all

139. Companies Act, 1900,63 \& 64 Vict., c. $48, \S 10(1)$.

140. Companies Act, 1907,7 Edw., c. $50, \S \S 19,21$.

141. See F.N. Paish, The London New Issue Market, in 4 THE DEVELOPMENT OF LONDON AS A FinANCIAL CENTRE 22, 24 (Ranald C. Michie ed., 2000).

142. Companies Act, 1929, 19 \& 20 Geo. 5, c. 23 , § 123.

143. MiCHIE, supra note 113, at 115.

144. Paish, supra note 141, at 24-25.

145. See CHEFfins, supra note 133, at 24-26.

146. MICHIE, supra note 113, at 262-63.

147. $I d$. at 268 . 
material information on an ongoing basis. ${ }^{148}$ Still, legislation establishing anything resembling a U.K. counterpart to the SEC did not come until the Financial Services Act of 1986.

If the LSE's efforts at self-regulation seem in general to have been laxer than those of the NYSE, there is a later chapter in this self-regulatory story in which the United Kingdom's efforts clearly outpaced those in the United States. Takeover bids first began to appear in the United Kingdom in the early 1950s, and by late 1959, the first voluntary code of conduct had been drawn up, largely at the request of the Bank of England, to regulate them. ${ }^{149}$ While often ineffective, this voluntary code eventually evolved by the late 1960s into the City Take-Over Code and its now well-known TakeOver Panel. In 1972, the Code was revised to require an acquirer to make a mandatory bid for all the target's shares once the acquirer crossed a specified threshold of stock ownership (generally thirty percent). ${ }^{150}$ The effect of this provision was to protect the right of the public shareholder to share in any control premium and to discourage stealth raids that sought to acquire control without the payment of such a premium. The United Kingdom's mandatory bid has, of course, now been incorporated into the Thirteenth Directive, but the more relevant point is that it encouraged dispersed ownership by effectively allowing the value of control to be held by public shareholders.

Thus, we come full circle: By a variety of means, including a substantial self-regulatory component, both the United States and the United Kingdom developed legal and institutional mechanisms that enabled dispersed ownership to persist. Generally, these mechanisms followed, rather than preceded, economic changes, but they did protect and facilitate the growth of dispersed ownership. Finally, conspicuously absent from this process was politics. No political party in either country appears actively to have raised the issue of securities market reform (or opposed such reform) as a major issue. Most importantly, if the separation of ownership and control arrived in Britain somewhere between the late 1930s and 1970 (as British historians and academics believe ${ }^{151}$ ), it occurred at a time when Britain was under a Labour government whose philosophy can be fairly characterized as somewhere between social-democratic and outright socialistic.

148. See L.C.B. GOWER, THE PRINCIPLES OF MOdeRn COMPANY LAW 437 (1954).

149. See Alexander Johnson, The City TAKe-OVER CODE 19-20 (1980).

150. Id. at $91-92$.

151. See supra note 131 and accompanying text. 


\section{A Civil-Law Contrast: The French Experience}

While both the NYSE and the LSE were and remain private bodies, the Paris Bourse has historically been a state-chartered monopoly, run under very close governmental supervision. ${ }^{152}$ Far older than either the LSE or the NYSE, it traces its origins back to 1141 , when Louis VII granted a charter to the Guild of Moneychangers, giving them the sole right to operate on the Great Bridge of Paris. ${ }^{153}$ For most of its existence, it fought to preserve this monopoly status, which was formally reconfirmed by Napoleon, who in 1807 gave the exclusive right to the Bourse's stockbrokers (known as agents de change or agents) to effect transactions in listed securities. ${ }^{154} \mathrm{~A}$ securities transaction off the Bourse was made unlawful, and only an agent de change was permitted to transact business on the Bourse. ${ }^{155}$ In effect, the Bourse was a publicly administered monopoly, and its agents de change had the status of civil servants, who were formally appointed to office by the Minister of Finance after first passing a civil service-like exam. ${ }^{156}$ This insulated, monopoly-like status of the Bourse persisted until the late 1980s, when both global competitive pressures (including London's "Big Bang") and a series of scandals forced a wholesale restructuring of the French securities market. ${ }^{157}$

Nonetheless, as of the late nineteenth century, the Paris Bourse was the one potential international rival to the LSE, and it actively traded American railroad securities and later American industrial stocks (such as U.S. Steel). To an even greater extent than London, its market focused on foreign securities, chiefly governınental and railroad bonds. ${ }^{158}$ In its competition

152. See, e.g., NORMAN S. POSER, INTERNATIONAL SECURITIES REgUlation 381-86 (1991); ThierRy SCHOEN, THE FRENCH STOCK EXCHANGE (1995). For a contemporaneous account of the Bourse during the early twentieth century, see W. PARKER, THE PARIS BOURSE AND FRENCH FINANCE (1919).

153. Margaret G. Myers, Paris as a Financial Centre 146 (1936). For the fullest account of the history of the Paris Bourse, see ÉMILE VIDAL, NAT'L MONETARY COMM'N, THE HiSTORY AND METHODS OF THE PARIS BOURSE, S. DOC. No. 61,573 (1910).

154. See POSER, supra note 152, at 381. The Paris Bourse was briefly closed during the French Revolution.

155. Id. It should be noted that there were a number of regional exchanges in France and a "curb" exchange, but these did not generally compete with the Bourse with regard to securities listed there.

156. See MYERS, supra note 153, at 146-47; Leslie A. Goldman, Note. The Modermization of the French Securities Market: Making the EEC Connection, 60 FORDHAM L. REV. S227, S231 n.28 (1992).

157. For a brief overview of this process, see id. at S230-36.

158. Myers presents data showing that between 1869 and 1908 , foreign securities owned as a percentage of all securities owned in France ranged between 32\% (in 1869) and 36\% (in 1908), with a decline to $27 \%$ between 1880 and 1890 (as a result of France's indemnity obligations arising out of the Franco-Prussian War). MYERS, supra note 153, at 136. Between 1908 and 1913 (or just prior to the outbreak of World War I), new issues of foreign securities in France always exceeded (and sometimes more than tripled) new issuance of French securities in France. Id. at 
with the LSE, however, the Bourse was subject to an immense, selfimposed handicap: The Bourse's agents de change were permitted to act as commission brokers only and never to function as dealers or principals. ${ }^{159}$ To be sure, the LSE also did not permit a member firm to be both a broker and a jobber (that is, a "dealer" in the United States parlance), but it did permit and encourage jobbers to function, and it thereby gained its liquidity from them.

By barring from its trading floor any financial intermediaries who could take positions in stocks in the absence of equilibrating customers' orders, the Paris Bourse thus effectively denied itself liquidity. Partly for this reason, a shadow market, known as the Coulisse, arose to fill this void, but, even though it occasionally threatened the Bourse during this era, it principally served as a market for unlisted securities. Indeed, when in the 1890 s the brokers on the Coulisse began to challenge seriously the Bourse's monopoly, the Bourse secured legislation that effectively immunized it from competition.

The Bourse's status as a protected monopoly was by no means unique; rather, it was the standard French pattern. Elsewhere, in the United States, the United Kingdom, and Germany, exchanges competed and the winner became dominant. In France, the government chose the winner. Similarly, the French government chose and chartered the dominant investment banking house of the era. Perhaps the most important French financial innovation of the nineteenth century was its creation in 1852 of the world's first major corporate investment bank-Société Générale de Crédit Mobilier, which became the template for a series of successor institutions. ${ }^{160}$ Designed as an investment bank to promote industrialization, it both advanced promotional loans and underwrote the securities of its clients, and it proved to be an engine of French economic growth for its brief, fifteen-year existence. ${ }^{161}$ But in both the rise and fall of Crédit Mobilier, the French government was deeply implicated. Originally, it was founded under the patronage of Napoleon III, who saw it as a statecontrolled rival to the House of Rothschild. But, because it came to rival and infringe the monopoly status of the Bank of France, Crédit Mobilier had envious rivals from its outset (including, of course, the formidable

138. Myers attributes the popularity of foreign issues to both their higher interest rates and the greater commissions they paid stockbrokers. Id. at 135-36.

159. Id. at 146; PARKER, supra note 152, at 28.

160. On the rise, fall, and significance of Crédit Mobilier, see RONDO E. CAMERON, FranCE AND THE ECONOMIC DEVELOPMENT OF EUROPE, 1800-1914, at 98-144 (1961). The principal innovation in the design of Crédit Mobilier was its capital structure. Most banks obtain most of their capital from depositors, and having short-term liabilities, can only safely make short-term loans. Crédit Mobilier attempted to obtain long-term capital by issuing debentures, but never received full governmental permission for the debenture issuances it originally planned. $I d$. at $128-31$.

161. Id. at 105-06. 
House of Rothschild). Its failure in 1867 came not from a normal financial collapse, but rather from a liquidity crisis occasioned by the government's refusal, prodded by the Bank of France, to allow Crédit Mobilier to issue additional debentures. ${ }^{162}$ In short, no institution, however important, truly escaped the government's control.

Similarly, the Bourse was also administered, according to a contemporaneous observer, as a unique "monopoly which operates under the strict and comprehensive control of the French Government." 163 Specifically, French law fixed both the commission rates on securities transactions and the number of agents de change. ${ }^{164}$ In sharp contrast to both the LSE, where the number of seats was unlimited, and the NYSE, where the number of seats was limited but seats could be freely sold, seats on the Bourse were both fixed in number and not freely tradable; rather, seats were usually handed down from father to son. If there was no male heir, the Minister of Finance would typically accept a nomination made in the will of the deceased agent de change (or submitted by his executor), ${ }^{165}$ but the process of transfer still required that the proposed transferee be an eligible individual, who could have no interest in any commercial enterprise and who had to pass a qualifying exam, before the proposed transferee could be voted upon by the membership and then have his name passed on to the Ministry of Finance. ${ }^{166}$ As a result, because (1) the agents de change could not serve (or profit) as dealers, (2) no real market in seats existed, and (3) agents de change were jointly and severally liable for the business debts of their fellow agents, ${ }^{167}$ French stockbrokers remained small and undercapitalized. As much civil servants as economic entrepreneurs, the Bourse's agents de change could not develop into securities firms, as could their British and American counterparts. Moreover, limited to a total size of seventy members (each of which could employ no more than six clerks on the trading floor), the Bourse was also logistically constrained.

The important point here is not simply that the Bourse was inefficiently designed or structured, or that it lacked liquidity, but that in a fundamental sense, it lacked true owners who had the incentive to improve or change its structure and rules. Denied the ability to profit as dealers or to transfer their seats freely, the stockbrokers of the Bourse had limited incentives to improve the Bourse's operation or regulation. Indeed, knowing the historic French tendency toward centralization and strong governmental regulation,

162. Id. at $128-31$.

163. PARKER, supra note 152 , at 28.

164. In 1898, the number of agents de change was raised from sixty to seventy as a move to block the competitive efforts of the Coulissiers. Id. at 34.

165. PARKER, supra note 152, at 28.

166. See MYERS, supra note 153, at 146-47.

167. Id. 
the ideal of self-regulation may have seemed both alien and infeasible to them-if it were ever considered at all.

In sum, the government regulated all aspects of the Bourse's operation. Even the decision to list securities had to be approved by the Ministry of Finance, and the decision to list a foreign security required the additional approval of the Ministry of Foreign Affairs, ${ }^{168}$ which was sometimes withheld. ${ }^{169}$ Even more invasive of the Bourse's autonomy was the decision of these ministries to require the Bourse to list foreign securities, a proposal that had been rejected by the Bourse. ${ }^{170}$ By the end of the century, as international tensions mounted, a Bourse listing came to be seen by the ministries as a low-cost tool of French foreign policy. ${ }^{171}$ Obviously, there was a cost to such a policy, but it fell instead on investors and the financial infrastructure.

Nor did close governmental regulation result in high public esteem for the Bourse. While the NYSE strove to enhance and protect its reputational capital, the reputation of the Bourse among French citizens was, from the nineteenth century on, that of "a place of mystery, or even danger," 172 which Emile Zola attacked and ridiculed in his popular novels. ${ }^{173}$ During the early twentieth century, the "flood of foreign issues into France drew criticism," according to one contemporaneous observer, in part "because of the poor quality of many of the securities." ${ }^{174}$ Neither the banks that issued securities nor the government exercised "adequate supervision over them," ${ }^{175}$ she reports. Yet, at the same time, the "Bourse was under tighter governmental control than were the markets of any other Western European country." 176

This combination of tight control and poor reputation presents a puzzle. Why did not the government or, at least, the Bourse itself intervene to exclude low-quality issuers? One answer is that neither the banks nor the government had much interest in improved regulation. ${ }^{177}$ The banks seldom held the securities they underwrote, but sold them to relatively small and often unsophisticated consumers. The government often had political

168. Id. at 147 .

169. PARKER, supra note 152, at 28.

170. CAMERON, supra note 160 , at 82 .

171. Id.

172. Keith Nunes et al., French and SEC Securities Regulation: The Search for Transparency and Openness in Decision Making, 26 VAND. J. TRANSNAT'L L. 217, 219 (1993).

173. E.g., EmILE ZOLA, L'ARGENT (Librairie Générale Française 1998) (1891). L'Argent detailed the experiences of its young hero in a mysterious investment bank that vaguely resembles Crédit Mobilier.

174. MYERS, supra note 153 , at $136-37$.

175. Id. at 137 .

176. Goldman, supra note 156, at S230.

177. This is the answer given by MYERS, supra note 153, at 137. 
reasons to list (or reject) foreign securities, ${ }^{178}$ and in any event profited handsomely on the taxes to which it subjected such issuances. ${ }^{179}$

This answer still leaves open the question of why the Bourse's own members did not seek to exclude low-quality issuers, as the NYSE had done early on and as the LSE eventually did. One hypothesis is that tight governmental supervision plus the limited economic stake of the agents de change suffocated any attempt at proactive self-regulation. As noted earlier, the Bourse's members would not share as fully in the gains from an improved public reputation as would, for example, the NYSE's members, because the Bourse's brokers were more restricted in their ability to profit as owners. But, even beyond this organizational point, there was still a deeper problem that is possibly inherent in the civil law. As one observer wrote in 1919 with particular reference to the Bourse: "The rigid governmental regulation of the Continental bourses is a practice that finds no counterpart in the English-speaking world, where each man is supposed to look out for himself." 180

To generalize, while common-law countries assumed there was a zone of private activity within which individuals were expected to protect their own interests, no such assumption influenced the civil law, which was inherently and pervasively paternalistic. The underlying reasons for this contrast have been most fully explored by the British historian and anthropologist, Alan Macfarlane, who has explained the rapid rise of industrialization in the United Kingdom as largely based on the fact that England had much earlier and uniquely evolved into a "highly developed and individualistic market society" characterized by "absolute ownership" of private property and high labor mobility. ${ }^{181}$ Never truly feudal, England was, from at least the thirteenth century on, he finds, a land of small property owners in which private contractual relationships were recognized, respected, and enforced by the courts. In short, entrepreneurial activity did not need the blessing of the state or sovereign and was generally not within their legitimate concern.

In contrast, in truly feudal societies, power came from the sovereign, and the sovereign - often aided by a powerful, permanent, and centralized bureaucracy-intervened in and oversaw most matters of consequence. Thus, it is symptomatic that the Paris Bourse evolved out of a twelfth-

178. Id. at 136; see CAMFRON, supra note 160 , at 82 .

179. MYERS, supra note 153 , at 137.

180. PARKER, supra note 152 , at 112.

181. MACFARLANE, ORIGINS, supra note 16, at 165. According to Macfarlane, an active market in land ownership plus a high degree of economic mobility allowed citizens having no position in the aristocracy to assemble significant wealth in medieval England, which was far less possible in France during the same era. For a fuller consideration of Macfarlane's views, see infra notes 225-229 and accompanying text. 
century concession by Louis VII to the Guild of Moneychangers. ${ }^{182}$ From these feudal origins came a tradition of close government involvement in all matters of economic consequence, which was precisely the opposite of the English tradition. More to the point, the natural consequence of this intrusive governmental regulation of private economic activity was arguably to stifle innovation and, in particular, any effort at self-regulation.

Centralized governmental control also had its natural allies because those regulated could then look to the government for protection from new competitors. Thus, the Bourse turned to the government for protection from its chief competitor, the Coulisse, and generally received it. ${ }^{183}$ In turn, given the Bourse's de facto monopoly status, the Bourse lacked the spur of competition to induce it to innovate (at least prior to the appearance of global competition in the 1980s). Yet, even in the face of greater competition, self-regulation might still not have developed during the late nineteenth century. Observers of the French business scene have long noted that "[i]n French business law, everything is proscribed unless explicitly permitted under the country's legal code." 184 Thus, to the extent that the civil law (especially in France) assumed direct governmental control of business activity, it tended to create static entities unlikely to innovate on their own.

In fairness, an important ambiguity surrounds this proposed explanation for the apparent difference in paternalism between common-law and civillaw countries. To the extent that the Bourse was a private monopoly, it made economic sense for the government to regulate it more closely than one would regulate a private entity in an open and competitive market; one would not defer lightly to, or encourage, private lawmaking by a monopoly. ${ }^{185}$ Potentially, two alternative hypotheses are possible: (1) The civil law inherently discouraged private lawmaking; or (2) having created a private monopoly (perhaps unwisely), French authorities could not defer to it, but instead logically recognized the need to regulate it closely (often, however, with the government's interest in maximizing tax revenues or achieving foreign policy goals overriding investor interests in the determination of actual policies). Still, even if there was a justification for not permitting the Bourse to become a self-regulating body, this justification does not extend to the persistent preference of the French government throughout the late nineteenth century for protecting the monopoly status of the Bourse. Rather than encourage competition, the French approach was to create a centralized monopoly and then regulate it

182. Supra note 153 and accompanying text.

183. Supra notes $156-160$ and accompanying text.

184. La Grande Boum, ECONOMIST, Oct. 1, 1988, at 83.

185. This thesis is implicit in Vidal's work, although not expressly stated as such. See VIDAL, supra note 153 , at $8-9$. 
closely. ${ }^{186}$ The bottom line consequence was to preclude private selfregulation.

The suffocating impact of close governmental regulation becomes clearest when we contrast the simultaneous development of the Paris Bourse and the NYSE during the nineteenth century. From its inception, the NYSE "operated a miniature legal system, with its own rules governing securities trading and its own mechanism for resolving trade-related disputes." ${ }^{187}$ In so doing, the NYSE "drew upon a centuries-old AngloAmerican tradition of self-regulation by mercantile groups." ${ }^{188}$ To be sure, development of this self-regulatory capacity was especially important during the early nineteenth century because the American legal system regarded many of the standard contracts that securities dealers entered into with each other as essentially gambling contracts and would not enforce them. ${ }^{189}$ This judicial neglect of (or hostility toward) the securities industry may have been the principal factor that initially compelled the United States securities industry to rely on self-regulation. Even so, what is most noteworthy here is that the common-law system could disapprove of an industry's practices (and in truth view them as but amoral gambling), but still tolerate the industry to function without state intervention or supervision.

In any event, if self-regulation on the NYSE was born of necessity, it quickly developed a momentum of its own. The industry soon found that its use could be expanded to achieve other goals, including that of enhancing the NYSE's (and the infant industry's) reputational capital. In contrast, in Europe, where every issue of consequence was regulated by law or needed to be referred to the appropriate ministry for approval, Continental exchanges were not positioned to develop self-regulation as a means of private law-making in their own common interest.

\section{The German Experience: Statist Intervention That Stunted the Market}

If the French experience shows the state creating a securities market as a state monopoly, the German experience reveals the opposite: the state disfavoring the securities market, intervening aggressively, and ultimately stunting its potential growth. Both attitudes-the state as protector and the

186. As discussed infra, Professor Alan Macfarlane argues that this structural tendency toward centralization and hierarchical control was the dominant approach in most countries, with only Holland and later England developing a decentralized society that truly encouraged free markets. See infra notes 225-230 and accompanying text.

187. BANNER, supra note 81 , at 271.

188. Id: see also William C. Jones, An Inquiry into the History of the Adjudication of Mercantile Disputes in Great Britain and the United States, 25 U. CHI. L. REV. 445 (1958) (discussing this tradition).

189. BANNER, supra note 81, at 271-72. 
state as antagonist-are opposite sides of the same civil-law coin in which the state plays favorites and regularly intervenes in private economic decisionmaking. This presumption of statist intervention contrasts sharply with the neutrality and indifference shown by common-law authorities to the growth of securities markets during the late nineteenth century in both the United States and the United Kingdom. Ultimately, securities markets appear to have fared better under a regime of benign neglect in the United States and the United Kingdom than under the favoritism or antagonism of France and Germany, respectively.

Historically, the two principal German securities markets trace back to origins well before the founding of the NYSE or the LSE. The Frankfurt Exchange was founded in 1585 and the Berlin Exchange was established in $1685 .{ }^{190}$ But, as with other exchanges of the period, they traded debt securities and commodities almost exclusively and were not serious rivals to the London or Paris exchanges prior to German unification in $1871 .^{191}$ Throughout this era, the Prussian government intervened periodically in the bond market, usually with a heavy hand. Sometimes, it banned the trading of the bonds of a specific foreign government, and, once, in 1842, it banned "all dealings in foreign bond issues." 192 Two years later, fearing that speculation in railroad stocks had reached a dangerous level, the Prussian finance minister unilaterally declared "all transactions for future delivery null and void." 193

As in the United States, the catalyst for the emergence of investment banking as an industry and for the growth of the equity securities market was the enormous need for capital of the German railroad industry. ${ }^{194}$ Until the 1850 s, those German railroads that were privately organized were financed by underwriting syndicates composed of traditional investment banking partnerships. These partnerships were relatively small and, even when organized as syndicates, found it difficult to underwrite securities in the amounts needed by the rapidly expanding railroad industry. Recognizing that they needed to create larger-scale entities to provide longterm financing for their clients, both the banking industry and their clients lobbied the Prussian government to charter banks organized as joint stock companies, which entities would thus have limited liability. ${ }^{195}$

190. GERMAN CAPITAL MARKET LAW 3 (Ulf R. Siebel et al. eds., 1995).

19!. 1871 is the year of the German Imperial Constitution, which reflected the incorporation of the Southern German states into Imperial Germany. For an overview, see MOMMSEN, supra note 14

192. Emil Friend, Note, Stock-Exchange Regulation in Germany, 16 J. POL. ECON. 369, 370 (1908). The Prussian government may have been motivated by the belief that banning foreign bond trading would "preserve a market for its own bonds." $I d$.

193. Id. This decree was ultimately overtumed by the courts. Id.

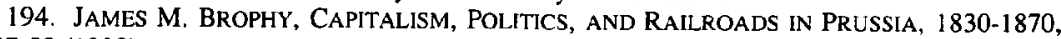
at 87-88 (1998).

195. Id. at 89-106. 
This goal was, however, repeatedly frustrated by the German crown and its bureaucracy, which feared the creation of large independent banks. The result was a major political collision between, on the one hand, the Prussian aristocracy, whose wealth was largely agriculturally based and who feared further industrialization, and an emerging business and commercial middle class that essentially wished "to practice trade free of government wishes and restrictions." 196 This confrontation came to a head in 1856 when, having been rebuffed in their attempts to found joint stock banks by the government's refusal to issue charters, certain leading German financiers organized "commandite banks." 197 Commandite firms were substitutes for joint stock corporations and basically resembled limited partnerships or modern-day limited liability companies in that silent partners provided capital but had de facto limited liability by virtue of the fact that their identities were not disclosed to outsiders. ${ }^{198}$ The Prussian government perceived the unauthorized formation of these banks to be an act of defiance and drafted a decree declaring commandite banks unlawful. Cooler heads within the Prussian government convinced the crown to relent for fear that an economic panic might result from any attempt to close down these banks. ${ }^{199}$ Still, the episode illustrates the limited range given to even the business elite to conduct business operations on a significant scale.

Gradually, the middle class won a series of battles that restricted governmental interference in the market, but they could not conclusively triumph in the larger war. ${ }^{200} \mathrm{~A}$ significant milestone came in 1870 , when they obtained free incorporation as of right, and, that same year, Deutsche Bank was founded, followed by Dresdner Bank in 1872. ${ }^{201}$ Formed principally to finance heavy industry, these "credit banks," or Grossbanken, combined commercial and investment banking; typically, they both purchased a newly capitalized firm's stock, underwrote its debt securities, and made it short-to-medium term bank loans. ${ }^{202}$ Although they were modeled after a French prototype, the Société Générale de Crédit Mobilier, the Grossbanken were distinctive and indeed constituted an institutional breakthrough in one critical respect: They were entirely private

196. Id. at 87.

197. Id. at 89-99.

198. Id. at 90 .

199. Id. at 89 .

200. Probably their first significant victory came in 1860 when the law permitting the government to nullify transactions in any securities was abrogated. Friend, supra note 192, at 370.

201. JAMES C. BAKER, THE GERMAN STOCK MARKET 6 (1970). The original Grossbanken were Schaaffhausensche Bank and Darmstädter Bank, which date back to the early 1850 s, id., but were created as the result of special political accommodations, BROPHY, supra note 194, at 91-92.

202. For the fullest history of the origins of the German credit banks, see JACOB RIESSER, The German Great Banks and Their Concentration, S. DoC. No. 61-593 (3d ed. 1911). This translation of an earlier German work by a professor at the University of Berlin was prepared for the National Monetary Commission in 1911. 
and were formed without the German government's direct backing or support. In contrast, Crédit Mobilier was founded under the auspices of Napoleon III and had little distance from the French government. ${ }^{203}$

Politically, the Grossbanken were "the expression of an assertive middle class," 204 which sought to break free from governmental control. From 1820 onward, "banking freedom" (or "Bankfreiheit") was the rallying cry of the German merchant or commercial middle class, ${ }^{205}$ and gradually over a half century, they partially achieved it. In contrast, the same issues never needed to be debated or pursued in the United States or the United Kingdom, where the government seldom intervened in economic matters. Still, as of the last quarter of the nineteenth century, the German economy had probably advanced further than the French toward recognition of a true private sector in which major financial projects could be undertaken without state approval or supervision. But the effort to secure a zone of business activity free from state intervention required a constant struggle, because the German state remained committed to active intervention in economic decision-making.

German business history over the remainder of the nineteenth century exemplified this pattern of recurrent state intervention. Although the best known of the Grossbanken were founded in the early 1870s, primarily to finance railroad and industrial expansion, the German government succeeded in 1879 , after a multi-year struggle, in nationalizing all private railroads. ${ }^{206}$ Control over the operation of private railroads had long been a source of friction, and ultimately the state insisted on total control. Although reasonable compensation was paid to stockholders, one cannot easily imagine the British or U.S. governments taking, or even contemplating, similar steps during this era. Later, in the $1890 \mathrm{~s}$, the government also severely tightened its regulation of the securities exchanges in a manner that deeply chilled trading and speculation. ${ }^{207}$ The point here is not that the conservative German government of Bismarck was hostile to the interests of business; rather, it assumed, in the manner of many civil-law countries, that it was naturally entitled to direct major business policies.

Often, this governmental intervention was benign and supportive of business. The best such example was Bismarck's policy of encouraging the development of the Grossbanken. Unlike his predecessors, Bismarck saw the great banks as natural allies in his policy of spurring the development of

203. For a review of the founding of Crédit Mobilicr and its significance, see RONDO E. CAMERON, France AND THE ECONOMIC DEVELOPMENT OF EUROPE, 1800-1914, at 134-203 (1961).

204. BROPHY, supra note 194, at 87.

205. Id. at 90 .

206. Id. at $169-70$.

207. See infra notes 213-222 and accompanying text. 
heavy industry; he envisioned, it was said, a political alliance of "iron and rye" - that is, a political marriage between the new industrial magnates and the landed Junker aristocracy. ${ }^{208}$ Yet his policies actually worked to the detriment of the development of securities markets. Essentially, his administration opened the bank window at the German central bank (the Reichsbank) for the Grossbanken by liberalizing the central bank's discount policy to such a degree that the Grossbanken could finance the needs of their client industries largely through debt, thereby diminishing their clients' need to resort to equity financing. The impact of this policy was to give virtually unlimited liquidity to the major German private banks. ${ }^{209}$ Secure in the knowledge that they could rediscount their loans to corporate clients with the Reichsbank, the major German private banks could "lend to the hilt," undeterred by the fear of illiquidity. ${ }^{210}$ In contrast, British commercial banks, although they also combined commercial and investment banking operations, were acutely aware that they could not finance long-term loans to corporate borrowers using short-term customer deposits. Nor was the Bank of England willing to extend similarly liberal discounting rights to its major banks; rather, it frequently resorted to credit rationing. ${ }^{211}$

This difference in the behavior of the central banks in Germany and the United Kingdom over the last decades of the nineteenth century is critical to an understanding of the thin character of the German equity capital market (and the highly-leveraged balance sheets of major German corporations). Had the German government not intervened to encourage liberal lending by its major banks, it seems likely that the growth of German securities markets would have paralleled that of the British market and produced a slow evolution toward dispersed ownership. After all, the Grossbanken largely controlled the securities exchanges and profited from securities underwritings. Yet if the central bank in Germany would in effect underwrite loans to major German corporations while the central bank in England would not do the same for its banks, it should be no surprise that heavy industry was financed by debt to a much greater extent in Germany than in the United Kingdom and that German corporations had less need to raise equity capital in their securities markets. Rationally, there was no

208. Bismarck is nomally credited with brokering such an alliance between heavy industry and the agrarian Junker aristocracy, which came at the expense of other commercial groups. See BROPHY, supra note 194, at 170 . Of course, low-cost loans by the state to the largest banks with the expectation that they would lend to heavy industry could be an important part of this political arrangement. Infra notes 209-210 and accompanying text.

209. Richard H. Tilly, Germany Banking, 1850-1914: Development Assistance for the Strong, 15 J. EUR. ECON. HIST. 113, 144-45 (1986).

210. Id. at 145; see also GARY HERRIGEL, INDUSTRIAL CONCENTRATIONS 6 (1996) (agreeing with Tilly that major German banks pooled scarce capital to subsidize heavy industry).

211. Tilly, supra note 209 , at 145 . 
reason for a German corporation to seek expensive equity capital when it could receive subsidized loans orchestrated by the state. Finally, because the United States in this era did not even have a central bank, ${ }^{212}$ there was no possibility that it could encourage its commercial banks to be similarly generous in order to finance industrialization in the United States.

Beyond simply encouraging risky, promotional lending that made equity financing less necessary or attractive, the German government took far more aggressive steps in the 1890s that effectively stunted the development of its then-growing securities markets. Ironically, the precipitating cause of this tightened regulation was a series of speculative bubbles and manipulations that occurred in the German commodities markets, not in the securities market. In 1888, speculators cornered the coffee market on the Hamburg Exchange; in 1889, a dramatic market break occurred in sugar prices; and in 1891, an attempt to corner the wheat market on the Berlin Exchange failed, but resulted in the collapse of several banks and brokerage firms. ${ }^{213}$ These events touched off a wave of agrarian protests directed against speculators whom farmers and their allies saw as responsible for a downward trend in grain prices. ${ }^{214}$ Because the German exchanges traded both commodities and securities, reformers began to lobby generally for reform of exchange trading, based on a popular sense that price manipulation was pervasive and that ordinary investors needed to be paternalistically protected. After a three-year study by a government commission, the Stock Exchange Law of 1896 was enacted to curb these abuses, but an irate legislature went well beyond the commission's original, more cautious proposals. All told, the process seemed to anticipate the same angry legislative response that later occurred in the United States following the crash of 1929, culminating in the enactment of the federal securities laws in the early 1930s. The difference was that the German legislation effectively eclipsed its market. ${ }^{215}$

Even prior to the 1896 law, the Imperial Stamp Act of 1894 had doubled the tax rate on securities transfers, and this tax rate was further raised in 1900 to triple the pre-1894 rate. ${ }^{216}$ Not only did this chill securities

212. Andrew Jackson's veto of the Second Bank of the United States resulted in the United States being without a central bank to provide bank liquidity throughout the remainder of the nineteenth century.

213. BAKER, supra note 201, at 7; Emest Loeb, The German Exchange Act of 1896, 11 Q.J. ECON. 388, 389-91 (1897); Friend, supra note 192, at 371.

214. Loeb, supra note 213 , at $409-10$.

215. For the conclusion that the German markets were "stunted" by this legislation, see Mark J. Roe, Some Differences in Corporate Structure in Germany, Japan, and the United States, 102 YALE L.J. 1927, 1971 n.142 (1993). Some economic historians today doubt, however, that the 1896 legislation was principally responsible for the growth of concentrated ownership in Germany, even if it did interrupt the development of the German securities market. See infra note 218.

216. RIESSER. supra note 202, at 618-19. 
trading, it also moved trading off the stock exchanges. This occurred because the major German banks found that they could avoid the tax by internalizing their execution of customer orders. That is, if a German bank bought 10,000 shares and sold 8000 shares of the same stock, it could net these orders, and pay tax only on the 2000 share balance. The consequence was to permit the major banks to take business away from the smaller brokers and banks that had a smaller order flow and could not avoid the tax in this fashion. ${ }^{217}$ German shareholders quickly learned that they could substantially avoid the tax by leaving their stock in the hands of their bank. The result was to lock in place an already developing system of concentrated ownership under which German banks would vote the customers' shares as the customers might direct at the annual shareholder meeting, but not disclose the customers' identities. In truth, such a system is not significantly different from the practice of "street name" ownership in the United States, under which brokers hold securities registered in their names for their customers-except that in Germany this system was enforced by a punitive tax on stock transfer. Even more importantly, to the extent that banks internalized order flow, thus netting stock transfers at the existing market price without entering those orders in the market, the market lost liquidity and priced less efficiently. ${ }^{218}$

The 1896 law disrupted trading to an even greater extent by barring transactions on credit for many classes of securities and commodities transactions. ${ }^{219}$ The statute also required all "speculators" entering into exchange transactions to register publicly; failure to do so could lead speculative contracts to be declared null and void as gambling transactions. ${ }^{220}$ But the Act literally applied only to trading on an exchange.

217. Id. at $620-21$.

218. This phenomenon was recognized contemporaneously. Writing in the first decade of the 1900s, University of Berlin Professor Jacob Riesser described the banks' response to the tax legislation as equivalent to their "taking over the function of the exchange," resulting in an impairment "of proper price determination." Id. at 771-72. That the 1896 legislation eclipsed the German securities market does not mean, however, that this legislation should be assigned principal causal responsibility for the concentrated structure of share ownership in Germany. More recent historians have doubted that the 1896 securities legislation or the associated increases in securities transfer taxes truly explain the consolidation in German universal banks, which occurred throughout the last two decades of the nineteenth century and accelerated after World War I. See Caroline fohlin, Regulation, Taxation, and the Development of the GERMAN UNIVERSAL BANKING SYSTEM, 1884-1913 (SSRN Elec. Library, Working Paper No. $273,547,2001$ ), available at http://papers.ssm.com/paper.taf?abstract_id $=273547$. This interpretation notes that banks were usurping the role of the exchanges even prior to the 1896 legislation. Thus, to the extent that this revisionist interpretation is correct, the role of the state in encouraging and subsidizing low-cost loans to heavy industry again seems to outweigh the impact of legal or regulatory changes as the primary explanation for the relative decline of securities markets in Germany.

219. BAKER, supra note 201, at 63. In addition, a last minute legislative rider to the 1896 Act removed from the exchange seven industrial stocks so important that they accounted for seventy percent of trading at the time. Friend, supra note 192, at 372.

220. BAKER, supra note 201, at 63. 
Hence, although designed to curb speculation, the 1896 Act succeeded primarily in driving trading off the exchanges. The upshot was quickly to turn the traditional exchanges into "disorganized markets." 221

The impact of the 1896 Act was so draconian that it quickly produced a demand for its repeal, even within the trading public that it "protected," and portions of the law were in fact repealed in $1908 .{ }^{222}$ But the enhanced transfer tax remained in place, and volume did not return to the German market prior to World War I. The war's aftermath, in turn, triggered a series of economic disasters, including the runaway inflation of the post-World War I era that crippled the German securities markets until this last decade.

In this light, the disparity between the size of the German equity market and those of the United States and the United Kingdom appears to be less the result of differences in the legal rights accorded shareholders in the countries than the consequence of a strong statist policy in Germany designed to curb speculation and to achieve industrialization through bank finance. Never supportive of securities exchanges, an irate German legislature, reacting to scandals, enacted punitive legislation that virtually closed down the securities markets for a time. Thus, rather than evolving naturally toward concentrated ownership, the German experience-in contrast to those of the United States and the United Kingdom-reveals an initial evolution toward developed securities markets that was interrupted and stunted by regular state intervention. If this capsule history shows how centralized ownership persisted in Germany amidst great industrial expansion, it also shows that this pattern was planned and directed by the state, and not the result of natural Darwinian competition.

\section{E. A Preliminary Summary}

What have we learned from this tour of New York, London, Paris, and Germany? Seemingly, there is a difference between common-law and civillaw jurisdictions, but it does not appear to lie in different legal technologies. Rather, by the late nineteenth century, there was already a private sector in the United States and the United Kingdom into which the state did not normally intrude. In contrast, the state intervened incessantly in the development of securities markets in France and Germany, either to protect the Paris Bourse's monopoly in France or to favor the development of commercial banks in Germany. To be sure, significant differences exist between the French and German experiences. In Germany, private actors emerged and played a greater role, whereas in France, the state's monopoly

221. Id. at 65; see RIESSER, supra note 202, at 620-22, 720-22.

222. BAKER, supra note 201 , at 8 . 
was always zealously protected. But even in Germany, the state ruled with a heavy hand and regulated its securities markets into oblivion. ${ }^{223}$

Within the common-law world, the overriding policy was rather one of benign neglect. Even though the experiences of the NYSE and the LSE diverged, the greater activism of the NYSE seems primarily attributable to nonlegal factors, including (1) its greater exposure to competitive pressure in this era; (2) its different organizational structure; (3) its dependence upon foreign capital; and (4) its greater need to develop bonding and monitoring mechanisms, given the vulnerability of U.S. investors to the predations of the robber barons and the prevalence of judicial corruption. In short, private bodies, having different incentives, responded differently to the problems before them.

\section{III. “DOES LAW MATTER?” RECONSIDERED}

\section{A. Law and the Decentralized Common-Law World}

If self-regulation and private self-help measures appear to have been the principal catalysts for the growth of equity securities markets in the United States, a tension arises between this finding and the LLS\&V thesis that dispersed ownership and liquid markets arise only when minority shareholders are accorded strong legal rights. Nor is this tension new. Indeed, a precisely contrary position to that of LLS\&V has long been popular in the law and economics literature on securities regulation. Opponents of the United States's mandatory disclosure system have long argued that the SEC's disclosure requirements were unnecessary and wasteful because market mechanisms had already developed prior to 1933 that were sufficient to satisfy investors' real demand for information. ${ }^{224}$ These critics might interpret the foregoing capsule histories as proof that law does not matter and self-sustaining markets can arise and persist

223. That the German Exchange Act of 1896 was scandal-driven does not truly distinguish the German experience from that of the United States or the United Kingdom. Both the United States and, to a lesser extent, the United Kingdom had recurrent scandals during this era. Prior to the 1929 crash, the United States did not legislate on the national level, while the United Kingdom did not enact major legislation even in the face of the 1929 crash. Again, this may reveal the strength of the assumption in these common-law countries that the state did not interfere in the private sector.

224. This debate, which goes back to the work of George Stigler and George Benston in the 1960s, has been revisited by many commentators. See George J. Benston, Required Disclosure and the Stock Market: An Evaluation of the Securities Exchange Act of 1934, 63 AM. ECON. REV. 132 (1973); George J. Stigler, Public Regulation of the Securities Markets, 37 J. BUS. 117 (1964). But see Irwin Friend \& Edward S. Herman, The S.E.C. Through a Glass Darkly, 37 J. BuS. 382 (1964) (arguing that Stigler's data demonstrates the positive impact of the federal securities laws). For an updated discussion of the impact of the securities laws, see Carol J. Simon, The Effect of the 1933 Securities Act on Investor Information and the Performance of New Issues, 79 AM. ECON. REV. 295, 311-13 (1989). 
spontaneously without law. Such a conclusion seems, however, to overread the evidence, given the fairly uniform subsequent market histories of these diverse countries. In the United States, the United Kingdom, and Germany, political pressures emerged early in the development of equity securities markets that eventually resulted in legislative constraints on the private market. These pressures brought legislation in 1896 in Germany, in the 1930s in the United States, and at varying stages in the United Kingdom, both early and late.

Although the relative success of self-regulation in the United States may initially seem inconsistent with the "law matters" hypothesis, much depends on what we count as "law." Stripped to its essentials, the LLS\&V hypothesis asserts (or, at least, need assert) only that strong equity markets require strong minority rights. Those minority rights could in principle come from any source (legislative, judicial, or self-regulatory), or from a combination of sources. More to the point, the process by which strong legal protections are obtained could logically begin with self-regulation, which creates nascent rights that later are codified into mandatory law. In effect, some firms, in order to market their stock, experiment with new ways of signaling that they will treat minority shareholders fairly. As their efforts succeed in the market, minority shareholders demand that similar standards be imposed on other public firms, in part to reduce the cost to them of interpreting noisy signals. This sequential interpretation views the role of law in markets as essentially one of imposing market-proven standards on laggard firms.

Such an interpretation leaves open, however, the question of why selfregulation developed in common-law countries and not in civil-law countries. Here, the principal weakness of the LLS\&V thesis is its narrow focus on substantive legal rights. Viewing law in effect as only a type of technology, the LLS\&V thesis overlooks the possibility that law and legal institutions may have shaped the broader society, not just the rights of minority shareholders. When one's perspective expands to consider this broader context, differences between the common law and the civil law come into clearer focus. The British historian and anthropologist, Alan Macfarlane, has argued that only two European countries, England and Holland, deviated from the pattern of absolutism and increased centralization of authority that characterized post-feudal Europe from the thirteenth to the eighteenth centuries. ${ }^{225}$ In both countries, but particularly in England, the absolute authority of the sovereign was constrained by law. In England, in lieu of an absolute monarch assisted by a vast centralized bureaucracy, there occurred a "devolution of power through a complex of often voluntary and honorary power holders such as constables and the

225. MACFARLANE, RIDDLE, supra note 16 , at 280-85. 
justices of the peace." ${ }^{226}$ Ecclesiastical power was also confined, and a tradition of religious tolerance arose that further accelerated the movement toward decentralization and diversity. Finally, in place of the caste-like social structure of feudal Europe, a class system arose in which power and wealth tended to depend more on personal achievements. In truth, these conditions probably first crystallized in Holland, but it was a smaller country, surrounded by larger, envious rivals (including England), and its prosperity thus proved short-lived. ${ }^{227}$

Law, of course, was not the only force that produced this environment in which the worlds of political power and economic activity largely separated. But law may have played an important role. While the rest of Europe accepted Roman law during the late Middle Ages, which in turn enhanced the power of the sovereign, England persisted in the development of the common law that it inherited from its Germanic ancestors. ${ }^{228}$ As a result, Macfarlane concludes that "[ $\mathrm{t}] \mathrm{he}$ English judicial system was confused, unprincipled, inefficient and cumbersome. Yet it somehow protected the citizen against the state better than anywhere else in the world." 229

Why did the English judicial system prove better able than its civil-law counterparts to protect individual rights? Different answers are possible, but the core of any answer probably involves individuals' greater distance from the sovereign and their closer identity with the local community around them. ${ }^{230}$ Already decentralized, the English legal system furthered the decentralization of power elsewhere in society and thereby assisted the growth of a market economy, in part by referring the inevitable commercial disputes to persons independent of the sovereign or the bureaucracy under his control.

Decentralization in turn made possible private law-making and the growth of self-regulatory bodies. Ultimately, this in turn facilitated the development of market-based institutions, such as stock exchanges, and enabled them to adapt and to gain the trust of their customers. Much in the late nineteenth-century histories of stock exchanges in the United States and the United Kingdom, as contrasted with the histories of similar institutions in France and Germany, confirms this emphasis on decentralization and the growth of a private sector as the initial precondition. Most obviously, the fact that true stock exchanges first emerged in Amsterdam and later London

226. Id. at 280 .

227. Id. at $279-80$.

228. Id. at 280 .

229. Id. at 205 (acknowledging that Tocqueville recognized this capacity of the common-law system).

230. For a more detailed theory of why English judges and the English system were more independent of centralized control than the civil-law system, see Edward L. Glaeser \& Andrei Shleifer, Legal Origins (Oct. 19, 2000) (unpublished manuscript, on file with author). 
seems neither accidental nor unrelated to the earlier appearance of a pluralistic society. More to the point, what the emerging business class in Germany most desired during the late nineteenth century was precisely what the United States and the United Kingdom business classes already had: protection from arbitrary governmental interventions in the private sector. This desire translates easily (and in fact did translate in practice) into a powerful belief in the rule of law. ${ }^{231}$ But if German industries that resisted the government were nationalized (as the private railroads were in 18781879) and if the French financial industry never escaped close governmental control, the British and American entrepreneur of the same era had no such fears. Nationalization was unthinkable, and close governmental supervision had simply not yet been experienced.

Any attempt to derive basic political differences, such as the earlier separation of the private sector in common-law countries, from legal differences is necessarily speculative, and the causal influences are probably modest at best. Still, it does seem plausible to suggest that the common law was more hospitable to private ordering and to the channeling of private disputes to resolution mechanisms outside the boundaries of the state. Historians and civil-law scholars appear to agree that the civil law inherently tends to codify private law, while the common law rarely does so. ${ }^{232}$ Codification naturally adopts bright-line and prophylactic rules that leave less room for flexibility or innovation. Further, codified civil law usually seeks to eliminate all gaps in the law in order to minimize opportunities for judicial discretion. ${ }^{233}$ The natural impact of such comprehensive legislation is to crowd out the possibility for local variation, experimentation, or adjustments to changed circumstances. Similarly, in the view of some leading scholars, the civil law is inherently interventionist and "policy-implementing," whereas the common law tends to view its task as "dispute resolving." 234 This more passive, neutral, and indeed laissez-faire

231. For example, Professor Brophy, writing of the political desires of the late nineteenthcentury German business elite, observes: "The sole principle consistently upheld by businessmen throughout this era was perhaps the belief in law, especially as it affected property relations." BROPHY, supra note 194, at 171.

232. For this broad proposition, see ARThur VON MEHREN, ThE CIVIL LAW SYSTEM 3 (1957) (noting that the "first" difference between the common law and the civil law was that "in the civil law, large areas of private law are codified").

233. JOHN MERRyMAN, The Civil LaW TRADITION 30 (1969).

234. MirJan DamaŠka, The Faces of Justice and State AUTHORITY (1986). In Professor Damaßka's view, "[t] $]$ he legal process of a truly activist state is a process organized around the central idea of an official inquiry and is devoted to the implementation of state policy." Id. at 147. In contrast, common-law systems tend to view the judiciary as a coordinate branch of the government, not as a "hierarchical" organ of state policy. Id. at 29-46 (distinguishing Continental from the Anglo-American "machinery of justice"). The frequently made distinction between the adversarial process of common-law systems versus the "inquisitorial approach" of civil-law systems reflects and maps onto this deeper distinction between the judiciary as a coordinate branch versus a hierarchical organ. Possibly because of this difference, common-law systems seem to have accepted greater delegation of dispute resolution to 
approach of the common law seems more tolerant of efforts at private lawmaking and self-regulation.

A more concrete example of the manner in which the common law protected the autonomy of the private sector involves the ease and thoroughness with which it accepted private ordering mechanisms for commercial disputes. In the United Kingdom and the United States, commercial disputes seem to have largely migrated from the courts to private arbitration systems by no later than the early eighteenth century. ${ }^{235}$ An arbitration statute, enacted in the United Kingdom in 1697, gave formal recognition to private arbitration awards and required that they be judicially enforced. ${ }^{236}$ Even cases that were brought to court were frequently referred to arbitration, and some early U.S. legislation actually made arbitration compulsory for certain types of disputes. ${ }^{237}$ The new financial institutions that arose in the United States and the United Kingdom in the eighteenth century were quick to mandate arbitration, in part to keep themselves beyond the oversight of the courts. In 1768, merchants in New York founded the New York Chamber of Commerce and made one of its stated purposes the establishment of an arbitral forum for its members. ${ }^{238}$ When the NYSE was founded in 1792, Rule 17 of its constitution of 1817 mandated compulsory arbitration of all disputes among its members. ${ }^{239}$ Virtually all other exchanges and mercantile associations founded in the United States during the nineteenth century followed this pattern. ${ }^{240}$ Perhaps fear of judicial corruption spurred the aggressive American adoption of arbitration in the nineteenth century, but the original motivation was more simply that private adjudication could outperform public adjudication in terms of speed, cost, and accuracy. While arbitration was not unknown to civil-law jurisdictions, the common-law tradition gave it a more central role, and Anglo-American exchanges placed it at the center of their constitutional framework. Inherently, the growth of such private lawmaking institutions kept disputes out of the state's range of vision and thus reduced the opportunities for state intervention.

private arbitration systems. See Jones, supra note 188 (tracing the history of arbitration in AngloAmerican jurisprudence).

235. Id. at 458-59. Arbitration procedures appear to have been used in London since 1327. Id. at 455 n.56; Paul L. Sayre, Development of Commercial Arbitration Law, 37 YALE L.J. 595, 59798 (1928). Of course, the search for historical antecedents involving specialized commercial tribunals can take one back to the medieval fair (with its specialized courts) and the common-law staple (another specialized court). But as Professor Jones has shown, these institutions had died out by the Tudor period in England. Jones, supra note 188, at 451-52.

236. Id. at 455 .

237. In 1767, the New York legislature adopted such a compulsory statute for disputes involving merchants' accounts. $I d$. at 460 .

238. Id. at 461 .

239. Id. at 462 .

240. Id. at 462-63 (listing thirteen U.S. exchanges or trade associations with similar provisions). 
Nonetheless, this Article need not make exaggerated claims for the significance of the differences between the civil law and the common law. Clearly, a decentralized and indeed pluralistic society arose in Holland more or less contemporaneously with corresponding developments in England. Hence, it cannot be argued that the civil-law system precluded the separation of politics from economics or the emergence of a marketoriented private sector. All that might be plausibly asserted is that the common-law tradition was more conducive to the emergence and separation of a private sector and that self-regulation was more feasible once the state had effectively ceded operational control of that sector to private actors.

\section{B. The Sequence of Legal Change: Reinterpreting $L L S \& V$}

That equity securities markets could develop in a regime of private selfregulation does not end the story. Many private innovations arise, but do not persist. Moreover, the fact that markets arose in a specific fashion does not imply that this was the only, or even the least costly, means by which to encourage market development. Even though equity markets can arise in the absence of strong minority protections, it hardly follows that they can develop to their full potential in such an environment. In this light, selfregulation seems better viewed as a partial functional substitute for legal institutions, which can work but may still fall well short of optimal efficiency. That self-regulation played the sizable role that it did in the United States may be primarily attributable to the limitations of the United States judicial system in the late nineteenth century (i.e., perceived corruption plus the ability of the antagonists to escape judicial control by pitting one state's judges against those in another state). Had the judicial system been more reliable in this era, the same emphasis might not have been placed on self-regulation or on self-help measures to preclude any need for resort to courts. To suggest this is only to suggest that economic evolution is path-dependent and thus will follow different trajectories in different environments.

Still, the question needs to be squarely faced: What explains the pattern in both the United States, the United Kingdom, and most other developed economies that fairly comprehensive securities legislation has been enacted after markets have become established? $?^{241}$ This Article's answer is that the LLS\&V data does fairly suggest that securities markets cannot grow or expand to their full potential under a purely voluntary legal regime. If LLS\&V have not shown that common-law legal rules are a precondition to

241. I have no doubt that a host of public choice and interest group theories can be offered. However, the focus herc is on how to read the significance of the LLS\&V data. 
the appearance of equity securities markets, they may have shown that the persistence and growth of such markets are closely correlated with a strong system of regulation that sustains investor confidence. Sooner or later, securities markets predictably encounter crises and experience shocks that result in a loss of investor confidence. As discussed below, the recent experience in Europe and Asia, particularly in the transitional economies, has shown that there are limits to self-regulation, and that markets not supported by strong legal institutions can lose credibility during periods of economic stress. ${ }^{242}$ Conceivably, a strong system of self-regulation (as in the case of the United Kingdom's City Take-Over Code) may prove adequate to this challenge, but the line between self-regulation and indirect governmental regulation is often difficult to define. Even when a strong private institutional structure arises (as it did in the case of the NYSE), the incentive to continue in such an activist role does not necessarily persist. For example, the NYSE faced far more competition in the nineteenth century than it did in the mid-twentieth century, ${ }^{243}$ and in the absence of competition, a self-regulator may have less reason to enforce rules against its own members in order to preserve its reputational capital.

A second general observation is that legislative action seems likely to follow, rather than precede, the appearance of securities markets, in substantial part because a self-conscious constituency of public investors must first arise before there will be political pressure for legislative reform that intrudes upon the market. Phrased differently, the legislature cannot anticipate problems that it has never seen (much as it could not legislate with respect to the Internet before the Internet first appeared).

These observations lead to a proposed reinterpretation of the LLS\&V hypothesis that sidesteps the historical flaw in their analysis in order to

242. For an overview of the experience in the transitional economies of Central Europe following the Asian financial crisis of 1997-1998, see Coffee, supra note 64. The German Neuer Markt has also experienced a more recent crisis in the wake of the recent worldwide decline in high-tech stock prices. See supra notes 48-50 and accompanying text. Although the Neuer Markt established very high listing standards, exceeding those of its parent, the Deutsche Börse, it has experienced a series of scandals over the last iwo years. See Jack Ewing, The Neuer Markt: Can It Hang On?, Bus. WK., July 30, 2001, at 18; Alfred Kueppers, A Busy Bidder in Germany Highlights Flaws in Newer Markt's Efforts To Challenge Nasdaq. WALL ST. J., Aug. 6, 2001, at C11. Observers have attributed the persistence of these scandals to Germany's chronically weak enforcement of insider trading and anti-manipulation laws; in particular, enforcement of suspected insider trading and manipulation cases detected by Germany's securities regulator is delegated to local criminal authorities and hence rarely results in criminal prosecution. See Kueppers, supra. To the extent that this diagnosis is correct, it suggests that self-regulatory bodies necessarily rely to some extent on public enforcement and thus may face an unavoidable shortfall in deterrence when public legal institutions are weak.

243. The NYSE's principal rival between 1885 and World War I was the Consolidated Stock Exchange, which unlike the Curb Exchange (later the American Stock Exchangc) traded securities listed on the NYSE. See MICHIE, supra note 70, at 204-08. Eventually, the Consolidated Stock Exchange found itself caught between the NYSE and the Curb Exchange and closed, but in its heyday during the late nineteenth century, it was the low-cost rival to the NYSE that successfully competed to attract the small investor and the smaller company. 
focus instead on its central truth: While markets can arise in the absence of a strong, mandatory legal framework, they neither function optimally nor develop to their potential in the absence of mandatory law that seeks to mitigate the risks of crashes. To focus simply on the fact that equity markets can arise without a legal foundation ignores the other half of the historical record. A "crash-then-law" cycle has characterized the history of securities markets. ${ }^{244}$ The historical aim of securities regulation has chiefly been to reduce or mitigate the risks and consequences of such crashes. ${ }^{245}$

This assertion that legislative action will generally be necessary because private ordering cannot adequately protect investors (or society generally) from destructive market crashes requires examination from two distinct perspectives: (1) the United States experience, and (2) the recent global experience following the Asian and Russian financial crises.

\section{The United States Experience}

Within the United States, there has been a long-standing academic debate over the necessity for, and impact of, the federal securities laws. ${ }^{246}$ Seeking to disprove the need for legislation, George Stigler, the first and still the most vehement critic of the rationale for the federal securities laws, analyzed the impact of the Securities Act of 1933 and found that the variance in the relative price performance of new issues of securities declined by almost half after its passage ${ }^{247}$ Despite this dramatic change, Professor Stigler interpreted this data to mean only that riskier new issues were being excluded as a result of the Securities Act's passage. ${ }^{248}$ Subsequent analyses have, however, interpreted this pronounced reduction in price dispersion to mean that greater pricing accuracy resulted. ${ }^{249}$ Although the debate will predictably continue, an informed basis exists for

244. I borrow this term from Professor Frank Partnoy. Frank Partnoy, Why Markets Crash and What Law Can Do About lt, 61 U. PITT. L. REV. 741, 743 n.11 (2000); see also Banner, supra note 13 , at 850 (finding that all major instances of securities legislation followed market crashes).

245. For a careful study finding that market crashes are not isolated or aberrant phenomena, but are endemic to markets for deep-seated reasons, see CHARLES P. KINDLEBERGER, MANIAS, PANICS, AND CRASHES (1978). I do not mean to suggest that this goal has necessarily been well pursued by legislatures. The 1896 German Act illustrates counter-productive legislation. But this goal is very different from the goal of improving allocative efficiency or pricing accuracy, which much academic commentary assumes is the only proper rationale for securities regulation.

246. See supra note 224.

247. Stigler, supra note 224 , at $120-21$.

248. Id. at 124 .

249. See, e.g., Friend \& Herman, supra note 224, at 390-91; see also Merritt B. Fox, Retaining Mandatory Securities Disclosure: Why Issuer Choice Is Not Investor Empowerment, 85 VA. L. REV. 1335, 1369-80 (1999) (finding that federal securities laws increased pricing accuracy). 
believing that the federal securities laws increased pricing accuracy and the amount of meaningful information in the market. ${ }^{250}$

Nonetheless, that may not have been the United States Congress's principal concern in 1933. Having heard testimony that fraud and manipulation had been rampant in the securities markets during the $1920 \mathrm{~s}$, Congress was intent on strengthening the existing system of enforcement, which it did by creating the SEC and a liberalized system of antifraud liability borrowed in part from the United Kingdom. Although revisionist scholars have recently challenged the logic of this approach, arguing that exchanges are the superior regulator, ${ }^{251}$ severe constraints appear to exist on both the incentives and the ability of a private body (such as a stock exchange) to enforce rules against its member firms and its listed companies. ${ }^{252}$ As we have earlier seen, the LSE did not make a serious effort until probably after World War II. While considerably more aggressive than the LSE as a self-regulator, even the NYSE faced resistance from its listed companies when it sought to upgrade disclosure standards. For example, Merritt Fox has found that, although the NYSE continually upgraded its listing requirements applicable to newly listed firms, it was unable (or unwilling) to apply these new rules to earlier listed firms, which collectively constituted the great majority of the firms traded on the exchange. ${ }^{253}$ This is but one example of the enforcement shortfall that is inherent in any self-regulatory system. Such a shortfall is likely for several different reasons: (1) A private body has weak incentives to enforce rules

250. Fox, supra note 249 , at 1376-91. Most recently, new research has asserted that the introduction in the early 1980s of the SEC's mandatory "Management Discussion and Analysis of Financial Condition and Results of Operations" (which disclosures are set forth in Item 303 of Regulation S-K and must be included in all periodic reports filed with the SEC by "reporting companies") significantly improved the accuracy of share pricing in the U.S. equity markets. See Artyom Dumev et al., Law, Share Price Accuracy and Economic Performance: The New Evidence (June 25, 2001) (unpublished manuscript, on file with author). This is the strongest claim yet, based on statistical evidence, that mandatory disclosure improves the efficiency of securities markets.

251. Paul Mahoney, The Exchange as Regulator, 83 VA. L. Rev. 1453 (1997). Professor Mahoney agrees, however, that Congress was motivated to legislate by its perception that stock exchanges could not adequately prevent manipulation, in particular by stock pools. Id. at 1464-65.

252. For this purpose, securities exchanges and commodities exchanges do not differ substantially, and economic analyses of attempts by commodities exchanges to preclude market manipulation have been both critical and pessimistic. See Stephen Pirrong, The Self-Regulation of Commodity Exchanges: The Case of Market Manipulation, 38 J.L. \& ECON. 141 (1995).

253. See Fox, supra note 249 , at 1376-79. This pattern continues today on other exchanges. For example, the Deutsche Börse has recently been involved in a much publicized dispute with one of its better-known listed companies, Porsche A.G., because the latter will not provide quarterly financial results. Although the Deutsche Börse has as a result dropped Porsche from its mid-cap index, it has been unwilling to delist this prominent and highly profitable issuer. See Scott Miller, For Porsche Investors, Disclosure Matters Less than Rocking Results, WALL ST. J., Aug. 13, 2001, at C14 (noting that investors accepted limited disclosure where the company was highly profitable). 
protecting third parties against its own members and clients; ${ }^{254}$ (2) a private body has little ability to enforce its rules against nonmembers; (3) enforcement may be too costly for a private body to undertake on a thoroughgoing basis; and (4) private bodies necessarily lack the investigative tools and punitive sanctions that the state has at its disposal.

This limited enforcement effort should not be surprising. It is not simply a matter of weak incentives, but also of difficulty of proof. Conspiracies by their nature do not reveal themselves to the observer. Only the public enforcer can threaten criminal penalties or truly punitive civil fines, and only public authorities have investigative tools, such as the grand jury, search warrants, and subpoena power, at their disposal. Private regulatory bodies, including the NYSE, have limited incentives to enforce their rules in a manner that restricts trading volume or reduces listings, ${ }^{255}$ and have no sanction other than the denial of trading privileges in the case of rule violations by nonmembers. Yet, nonmembers may often be the parties most likely to engage in insider trading or other manipulative practices. Absent a public regulatory body, victims would predictably be left to enforce their rights through private litigation, and the high costs of enforcement may dissuade at least the small public investor from relying on such remedies. ${ }^{256}$ As a practical matter, the creation of the SEC gave public investors a public guardian to champion their rights-in effect, a public subsidy for the prevention of fraud. Such a subsidy is justifiable if fraud produces externalities, namely, disintermediation by investors who perceive themselves to be unprotected and thus move to safer investments in other markets. The more that stock markets are perceived to be an engine of economic growth, ${ }^{257}$ the more that the protection of investor confidence to prevent such disintermediation merits a priority as a public policy goal.

254. Professor Banner has found, for example, that market manipulation was the onc context where the NYSE seldom, if ever, enforced its own disciplinary rules. Stuart Banner, The Origin of the New York Stock Exchange, 1791-1860, 27 J. LEGAL STuD. 113, 138-39 (1998) (noting that the exchange often did not discipline parties to fictitious sales); see also WERNER \& SMITH, supra note 91 , at 32 (noting that the exchange forbade fictitious sales, but perpetrators were seldom punished). For a nearly contemporaneous discussion of the role of stock pools in the 1930s, see Twentieth Century Fund, InC., StOck Market CONTROL 108-10 (1934).

255. Close students of exchanges have recently made this observation. E.g., Banner, supra note 254, at 138-39; Pirrong, supra note 252; see also Marccl Kahan, Some Problems with Stock Exchange-Based Securities Regulation, 83 VA. L. REV. 1509 (1997) (doubting that the market for stock exchange listings will be characterized by vigorous competition).

256. This is particularly true in the United Kingdom where small investors may be deterred by its "loser pays" rule under which the losing side must pay the litigation expenses of the winning side. In the United States, private enforcement constitutes a greater deterrent threat, principally because of the availability of the class action, which did not develop, however, until the late 1960s.

257. See supra note 7 and accompanying text. 


\section{The Global Experience}

From a global perspective, a modern pattern is evident: As securities markets begin to grow and mature, the host country codifies its law and creates a permanent enforcement and regulatory agency. Between the 1960s and the 1980s, each of the major European countries copied the United States in creating a strong regulatory agency that was more or less modeled after the American SEC. ${ }^{258}$ Much of this legislation was, of course, crisisand scandal-driven, but it has not been subsequently cut back. The movement toward stronger regulatory authority has had a decidedly oneway character.

One crisis stands out above all others. Probably the strongest contemporary evidence that unregulated (or underregulated) securities markets are vulnerable to crashes and that the severity of these crashes is in large part attributable to weak corporate governance has emerged from the Asian financial crisis of 1997-1998. One important study of the Asian crisis has found that measures of corporate governance, particularly the effectiveness of protections for minority shareholders, explained the extent of the stock market decline in individual countries better than did the standard macroeconomic measures ${ }^{259}$ This unexpected result seems to rest on a behavioral finding: In good times, managers and controlling shareholders do not expropriate wealth from minority shareholders (or at least prudently constrain their rate of expropriation). But, when an adverse shock hits the financial system, the rate of expropriation soars, and the relative market decline will be worst in those countries that have the weakest protections for minority shareholders. ${ }^{260}$

258. The pattem seems almost uniform. France, traditionally the fourth largest securities market, created the Commission des Operations de Bourse (or COB) in 1967 and then greatly strengthened its enforcement powers in 1988. Goldman, supra note 156, at S235-37. The latter step was part of a sweeping deregulation of the French market that removed it from the direct control of the French Treasury. Italy created its Commissione Nazionale per le Società e la Borsa (Consob), or National Commission for Companies and the Stock Exchange, in 1974. Patrick Del Duca \& Duccio Mortillaro, The Maturation of Italy's Response to European Community Law: Electric and Telecommunication Sector Institutional Innovations, 23 FORDHAM INT'L L.J. 536, 576-77 (2000). In Brilain, the Financial Services Act of 1986 (FSA) created the Securities and Investments Board (SIB), which is in essence an SEC-like administrative agency that supervises a host of self-regulatory agencies. Philip Thorpe, Regulation of the Futures Market in the United Kingdom, in REgLlLATING INTERNATIONAL FinANCIAL MARKETS (F. Edwards \& H. Patrick eds., 1992). Only Germany remains a partial exception to this pattern, because it created in 1994 a weaker agency with only limited oversight powers over the securities exchanges. GERMAN CAPITAL MARKET LAW, supra note 190, at 8, 13-15 (discussing the Federal Supervisory Office for Secarities Trading (or BAW), which was created by the Second Financial Market Promotion Act in 1994). The German regulatory structure is currently in transition, however, as a consolidation of agencies is planned.

259. Simon Johnson et al., Corporate Governance in the Asian Financial Crisis, 58 J. FiN. ECON. 141, 142, 171-72 (2000).

260. This study found that three indices of legal institutions-"efficiency of the judiciary," "corruption," and the "rule of law" - were statistically significant in explaining exchange rate 
Other studies have found that a high percentage of family ownership characterized those Asian economies that suffered the worst decline and suggested that the high concentration of control rights in these firms exposed minority shareholders to expropriation. ${ }^{26 t}$ Examining the separation of ownership and control in 2980 East Asian corporations, Claessens, Djankov, and Lang found that more than two-thirds of these firms were controlled by a single shareholder, typically through pyramid structures and cross-holdings. ${ }^{262}$ Claessens, Djankov, Fan, and Lang concluded that the risk of expropriation of minority shareholders was the "primary" principal-agent problem for public corporations in East Asia. ${ }^{263}$

These findings have a "déjà vu, all over again" familiarity for those with knowledge of U.S. corporate governance in the 1920s. During this era, holding companies and investment trusts assembled vast pyramids in which the control rights and cash-flow rights of investors became widely separated, and large segments of the utility, railroad, and entertainment industries fell under the control of persons holding relatively modest equity stakes in proportion to the market capitalization of the firms they controlled. ${ }^{264}$ Following the 1929 crash, Congress legislated the leveling of some of these pyramids, ${ }^{265}$ and many of the rest collapsed under their own weight. In short, the U.S. experience dovetails with that of Asia: Poor corporate governance can either contribute to or intensify the losses in a

collapse, $i d$. at 171-72, and the last two also correlated significantly with the extent of stock market decline, $i d$. at 181 . It also found that "corporate governance variables explain more of the variation in exchange rates and stock market performance during the Asian crisis than do macroeconomic variables." Id. at 184 . Overall, it concluded that "[c]orporate governance can be of first-order importance in determining the extent of macroeconomic problems in crisis situations." Id. at 185.

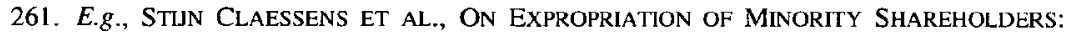
EVIDENCE FROM EAST ASIA (SSRN Elec. Library, Working Paper No. 202,390, 2000), available at http://papers.ssrn.com/paper.taf?abstract_id $=202390$ [hereinafter CLAESSENS ET AL., EXPROPRIATION]; STIJN ClaESSENS ET AL,, THE SEPARATION OF OWNERSHIP AND CONTROL IN EAST ASIAN CORPORATIONS (SSRN Elec. Library, Working Paper No. 206,448, 2000), available at http://papers.ssrn.com/paper.taf?abstract_id $=206448$ [hereinafter CLAESSENS ET AL, SEPARATION OF OWNERSHIP].

262. Claessens et AL., SEPARATION OF OWNERShIP, supra note 261, at 2. In contrast, Japanese firms, they found, were widely held and seldom family-controlled. 1 d. at 3.

263. ClaEsSEnS ET AL., EXPROPRIATION, supra note 261, at 2-3. They further concluded that such expropriation was chiefly effected through the separation of cash flow from voting rights. Id. at 2. In this light, it is noteworthy that the NYSE began to restrict attempts to separate cash flow from voting rights in the 1920s (well before the advent of the SEC) by imposing its "one share, one vote" rule. See supra notes 114-121 and accompanying text.

264. By 1932, holding companies had "not only obtained control of the great bulk of the nation's electric and gas utilities, but had also extended into such diverse fields as coal mining and retailing, oil foundries, textiles, agriculture, transportation, ice and cold storage, real estate, finance and credit, water, telephone companies, quarries, theatres, amusement parks" and other businesses. Louis Loss \& JOEl Seligman, SeCurities Regulation 229 (3d ed. 1989).

265. Section 11 of the Public Utility Holding Company Act of 1935 effectively required the liquidation of most holding companies in that industry, Id. at 234-37. 
market crash, and this danger has been the motive force behind much securities legislation.

\section{The Political Theory of Dispersed Ownership}

This Article's account of the rise of dispersed ownership in the United States and the United Kingdom disagrees also with the leading counterthesis to the LLS\&V hypothesis: that politics is the critical determinant and that legal differences simply flow from deeply rooted political values. The fullest and best statement of this position has been by Professor Mark Roe, who argues that because social democracies prefer the interests of other constituencies to those of shareholders, they will pressure corporate managers to subordinate shareholder interests, and only concentrated large shareholders can effectively compel managers to resist these pressures. ${ }^{266}$ In a nutshell, he argues that:

Aligning managers with dispersed shareholders is harder in social democracies than elsewhere: Owners dislike transparent accounting, which would give employees more information than many owners would like them to have, but transparent accounting is necessary for distant securities holders .... The strong control mechanisms of the hostile takeover and publicly known incentive compensation have been harder or impossible to implement in the social democracies. ${ }^{267}$

Arguably, this assessment is already dated, both because takeovers and transparent accounting have already come to Europe ${ }^{268}$ and because the older, post-war corporatist system of industrial relations seems to have broken down under the pressure of global competition and the cross-border mobility of capital and labor. ${ }^{269}$

266. Roe, supra note 12.

267. Id. at 603. Inevitably, this assessment that it is harder to align shareholder and managerial interests in social democracies invites the response: compared to what? Public shareholders would seem to face far greater difficulties in assuring managerial loyalty in the concentrated ownership systems of East Asia, where expropriation of minority shareholders seems the norm. See supra notes 259-263 and accompanying text.

268. With regard to the takeover movement in Europe, see supra notes 53-59 and accompanying text. Correspondingly, while it is possible that co-determination once discouraged transparent accounting, the inexorable movement toward a pan-European stock market is clearly bringing transparent accounting to Europe. See supra notes 46-52 and accompanying text. Listing on Germany's Neuer Markt requires that the listed company comply with international accounting standards, not simply German standards. See Vanessa Fuhrmans, Playing by the Rules: How Neuer Markt Gets Respect, WALL ST. J., Aug. 21, 2000, at Cl; infra notes 288-290 and accompanying text.

269. University of Chicago Professor Gary Herrigel has closely studied the German industrial model and reported that the pressure of "international industrial competilion" undermined the traditional German system of industrial relations in the 1990s. GARY HERRIGEL, INDUSTRIAL CONSTRUCTIONS 275-77 (1996). In his view, the traditional model of German industrial relations, 
But, even if we ignore these trends, the logic of Roe's thesis that social democracy discourages the separation of ownership and control encounters at least three basic problems. First, its premise that concentrated ownership is a defensive response to pressure from left-leaning social democracies seems doubtful, because it does not account for the presence of concentrated ownership in other countries. The most concentrated share ownership in the world appears to be in Asia, ${ }^{270}$ not Europe, and at least some of the East Asian countries in which this form of ownership has reached the highest known levels of concentration seem closer to plutocracies than to democracies. ${ }^{271}$ This is the dark side of concentrated ownership; put simply, the separation of cash-flow rights from voting rights can serve as a means by which those controlling the public sector can extend their control over the private sector. At a minimum, the prospect of crony capitalism - that is, closely interlocked political and economic leaderships, each reciprocally assisting the other-ensures that concentrated owners will need to become deeply involved in government in order to protect their positions from existing rivals, new entrants, and political sycophants. To be sure, ownership concentration may sometimes be a defensive strategy in a corrupt economy, but this has nothing to do with social democracy, and it implies an incestuous relationship between the dominant shareholders and political leaders.

Second, even if we assume that social democracies, however defined, do pressure managers to favor nonshareholder constituencies, it is far from clear that concentrated ownership would be a successful defense strategy. This is particularly true in countries such as Germany, where the largest shareowners are universal banks and other financial intermediaries. Both in Germany and elsewhere, large banks appear to be uniquely subject to governmental influence, not immune from it. ${ }^{272}$ In contrast, dispersed shareowners are both anonymous and potentially a powerful political

which he characterizes as "Social Democratic Modell Deutschland" or "organized capitalism," has already become outdated, with actual labor-management bargaining now occurring on a more decentralized basis, frequently at the plant level. Id. at 274-75, 281-85. As labor negotiations become localized, rather than national, the prospect of governmental intervention to pressure corporate employers, which seldom occurred even in the past, now recedes even further.

270. See generally ClAESSENS ET AL., SEPARATION OF OWNERSHIP, supra note 261 (reviewing the ownership structure of 2980 corporations in nine East Asian countries and finding that over two-thirds of the firms are controlled by a single shareholder, with voting rights frequently exceeding cash-flow rights as the result of pyramid structures and cross-holdings).

271. Claessens, Djankov, and Lang report that ownership of approximately seventeen percent of the total market capitalization in each of Indonesia and the Philippines can be traced to a single family (the Marcos family in the Philippines and the Suharto family in Indonesia). Id. at 3. Indonesia was found to have more than two-thirds of its publicly listed companies controlled by a family if control were equated with ownership of ten percent or more of the voting rights. Id. at 24.

272. See supra notes 206-212 and accompanying text for a discussion of the traditional dependence of the German universal banks on the Finance Ministry. 
interest group. If, as currently reported, ${ }^{273}$ ten percent of German citizens own stocks and nearly fourteen percent own mutual funds, this is a constituency that few democratically elected politicians would dare to pressure. Put differently, there is safety in numbers, because it is politically safer for a government to pressure a few large holders than an anonymous herd of small investors. Logically, one does not lightly pressure a mobile corporation, which can redeploy assets outside the country and whose increasingly international shareholders will expect such a response, but a social-democratic government can pressure large, concentrated shareholders, who often are less mobile and more visible.

In any event, the Roe hypothesis that concentrated ownership is a defense against overreaching by the social-democratic state frames a testable proposition: If concentrated ownership does outperform dispersed ownership in this special political setting, then corporations with concentrated ownership in such countries should exhibit greater profitability than those with dispersed ownership. But the data is precisely to the contrary. A recent study of 361 German corporations between 1991 and 1996 found "a significantly negative impact of ownership concentration on profitability as measured by the return on total assets." 274 Rather than protect shareholders, this study and earlier research have concluded that "concentration of ownership seems to further rent extraction." 275

Finally, whatever the strength of the economic logic of this hypothesized relationship between social democracy and ownership structure, its historical foundations are shaky. In both the United States and the United Kingdom, politics appears to have played no more than a negligible role in the rise of dispersed ownership, and concentrated ownership was established in Germany and France by the late nineteenth century, well before the earliest appearance of a social-democratic government in either country. In addition, Cambridge Professor Brian Cheffins has found that the separation of ownership and control in the United Kingdom actually occurred during a period in which British Labour governments were pursuing policies that can fairly be called social-

273. Ascarelli, supra note 49.

274. See Erik Lehmann \& Jürgen Weigand, Does the Governed Corporation Perform Better? Governance Structures and Corporate Performance in Germany, 4 EUR. FIN. REV. 157, 190 $(2000)$. This finding of lower profitability held true both for quoted and unquoted German firms and was found to support "the view that large shareholders inflict costs on the firm (e.g., rent extraction, too much monitoring, or infighting)." Id. at 190.

275. Id. at 164 (discussing earlier studies). Interestingly, there is some evidence that German firms with highly concentrated ownership "enjoyed higher returns during the 1970 s and early 1980s," but this positive impact then eroded or turned negative during the late 1980s and thereafter. Id. at 165 . Lehmann and Weigand conclude that increasing international competition may have reversed the former profitability of ownership concentration. Id. 
democratic. ${ }^{276}$ Under the Roe theory, such a political environment should have produced increasing concentration of share ownership, but it did not.

More generally, Professor Roe's claim that politics constrained the development of powerful financial intermediaries in the United States may overread the limited evidence. ${ }^{277}$ His hypothesis ignores that unconstrained institutional investors in the United Kingdom closely resemble their American counterparts, even though no regulatory inhibitions hobbled their growth. ${ }^{278}$ Other things being equal, the simpler model is preferable to the more complex. Here, the simpler model is that financial institutions greatly value liquidity and hence do not wish to hold large and illiquid equity stakes in business corporations. ${ }^{279}$ Concentrated ownership therefore occurs when legislative policies encourage it, and our earlier tour of the French and German experiences suggested that concentrated ownership was legislatively shaped by such policies. ${ }^{280}$

Finally, Professor Roe's thesis rests on the behavioral premise that large investors in social-democratic countries seek to avoid the culture of transparency that comes with the development of securities markets, because it would arguably subject them to even greater expropriation by the state. A problem with this reasoning, however, is that if concentrated ownership were an important defense mechanism against social democracy, then social democracies should logically seek to encourage ownership dispersion by, for example, enhancing transparency. Logically, on Roe's behavioral premise, left-leaning governments should favor the development of securities markets in order to gain greater control over the private sector. In principle, one should then observe private investors across Europe opposing the development of securities markets while the left advocates their growth. The reverse is probably closer to the truth, although, in fact, a broad consensus across Europe seems today to support the growth of securities markets.

To sum up, the Roe social-democratic thesis does not explain the origins of concentrated ownership in any country, certainly does not explain its persistence in Asia or much of the Third World, and only explains its survival in Europe if one accepts the debatable premise that a few large

276. See supra note 131 and accompanying text.

277. For a full statement of the claim, see Mark J. RoE, Strong Managers, Weak OWNERS (1994).

278. Bernard S. Black \& John C. Coffee, Jr., Hail Britannia?: Institutional Investor Behavior Under Limited Regulation, 92 MICH. L. REV. 1997 (1994).

279. I have argued this "liquidity versus control" thesis at considerable length elsewhere, Coffee, supra note 21 , and will not belabor it further here. Suffice it to say that banks, as institutions with short-term liabilities to depositors, have a major problem with making illiquid long-term investments.

280. The pattern is clearest in Germany where the Finance Ministry subsidized the largest banks with low-cost loans and in turn encouraged them to lend to heavy industry on a massive scale. See supra notes 208-210 and accompanying text. 
owners can better resist governmental pressure than can an anonymous herd of small investors. The better historical and political explanation for the bank-centered system of corporate governance that has dominated Europe until recently is that it maximized state control of the economy. ${ }^{281}$ Particularly in times of war and social turmoil during the last century, those in power-whether socialists or fascists-preferred a bank-centered system, because large banks were ultimately more subject to state control than were securities markets. ${ }^{282}$ That securities markets have developed slowly across Europe thus may well have a political as well as a legal explanation, but that political explanation is that power-seeking nationalists could use banks as their agents and that banks, once entrenched, had natural reasons to resist the rise of rivals for their business.

Moreover, the idea that the state should control and manage the economy was not a new idea in Continental Europe, but rather a continuation of policies and attitudes that dated back to feudal times. In this light, the real division is not between left and right, but between centralized and decentralized. Those countries-most notably the United Kingdom and the Netherlands-that were the most decentralized and that divorced economic activity from political control were, not surprisingly, the first to develop true securities markets.

281. For one version of this thesis, see Raghuram G. RAJAN \& LUIGI ZINGALES, THE

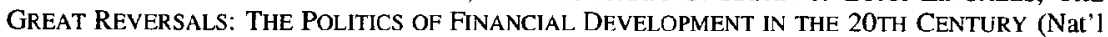
Bureau of Econ. Research, Working Paper No. 8178, 2001), available at http://papers.ssm.com/paper.taf?abstract_id=236100. Under their "interest group" theory of financial development, incumbents opposed financial development because it bred competition. This is certainly consistent with the French history and much of the German history. In France, the Bourse sought to disable the Coulisse from conducting a rival market. See supra notes 155 160 and accompanying text. Similarly, in Germany, the Junker aristocracy long resisted frec incorporation and the creation of incorporated banks. See supra notes 195-201 and accompanying text.

282. Rajan and Zingales examine the experiences of several countries during the early to middle twentieth century and find that, while ideologies differed, "the basic outcome did not: the working of financial markets was severely impaired by the intervention of the Government, which assumed a greater direct and indirect role in allocating funds to industry." RAJAN \& ZINGALES, supra note 281 , at 42 . The common denominator, they argue, is that, in the absence of external competition, the government and the bankers can "enter into a Faustian pact, with the government restricting entry and inter-bank competition, ostensibly in the interest of the stability of the system, and bankers obeying government diktats about whom to lend to in retum for being allowed to be part of the privileged pact." $I d$. at 41 . The government's goal in protecting banks from competition was to cause "private investment to flow through the banking sector because these flows could be more easily directed to preferred activities than if they went through the arm's length markets where the government had little control." Id. This is a powerful theory that applies both to the desires of European governments engaged in an arms race during the late 1930 s and Asian governments seeking to control the private sector in the 1990s. Better than Roe's social democracy theory of concentrated ownership, this theory fits the historical evidence. Indeed, although Rajan and Zingales do not discuss nineteenth-century Germany, its experience with the state encouraging the largest banks to subsidize sclected industries also is captured by their theory. See supra notes 208-210 and accompanying text. 


\section{Implications for Transitional Economies}

If this Article's assessment is correct that strong self-regulation was the principal catalyst for the appearance of an active and liquid market in equity securities and the arrival of dispersed ownership, then very practical implications follow. Even in countries with weak legal protections for minority shareholders, it may be possible for those firms that are prepared to bond themselves, install credible monitoring controls, and meet higher standards of disclosure to sell stock to dispersed public shareholders at prices exceeding that which a controlling shareholder would pay. Similarly, the void created by weak formal law can be at least partially filled by a functional substitute: strong stock exchange rules or other forms of selfregulation. These claims do not deny the desirability of stronger formal legal rules or the likelihood that shareholder values will be further maximized by such legal changes. But the thrust of this Article is to suggest that a very real payoff can be obtained from private ordering and credible corporate governance.

Speculative as this prediction may sound, there is already some persuasive empirical evidence to support it. If the United States equity market grew and attracted foreign capital, despite the highly-publicized predations of the robber barons, ${ }^{283}$ it is at least plausible that the same phenomenon could occur in contemporary Russia, where legal institutions appear equally weak or weaker. The available evidence suggests that a similar process is already well underway. Professor Bernard Black has found that firm-specific corporate governance practices do greatly affect the market value of publicly traded Russian companies ${ }^{284}$ Using corporate governance rankings prepared in 1999 by one Russian investment bank, he compared these ratings with a "value ratio" of actual market capitalization to theoretical Western market capitalization for these same firms prepared by another investment bank. The value ratios revealed the high discounts that investors applied to these firms, and they showed an enormous variation with some firms trading at only $0.01 \%$ of their theoretical Western market value, while others traded at nearly half their Western value. Most importantly, the correlation between the firms' corporate governance rankings and their value ratios was strikingly high and statistically significant. ${ }^{285}$ Even small changes in governance rankings produced

283. See supra notes 76-90 and accompanying text.

284. See Bernard S. Black, Does Corporate Governance Matter?: A Crude Test Using Russian Data, 149 U. PA. L. REv. 2131 (2001).

285. Professor Black found a very robust correlation between the value ratio and the governance ranking that yielded a Pearson $r$ equal to 0.90 . Id. at 2133 . He concluded that corporate governance was the "dominant determinant of the value ratio." Id. at 2143. 
substantial changes in firm value. ${ }^{286}$ The natural inference from these data is that corporate governance matters, but also that private actors can generate credible signals that at least partially satisfy investor demands for adequate governance. Thus, although a legal regime may provide inadequate protections itself, those firms that install a credible corporate governance structure can, through private ordering, achieve a much higher proportion of their potential value in a Western market. ${ }^{287}$ Obviously, the implications of this and similar findings are two-sided: Much can be done through private action, but full valuation may require Western-style legislation and enforcement.

The other aspect of the nineteenth-century American experience that appears to be in the process of being reenacted today involves stock exchange self-regulation. A century ago, the NYSE adopted rules that were considerably stricter than prevailing local law. Today, the Neuer Markt in Germany appears to be following its example. Created as an intended European rival to Nasdaq with the hope that it could provide a market for high-tech start-up companies, the Neuer Markt has grown from 2 to 302 listed companies in only three years, with a current aggregate market capitalization of $\$ 172$ billion. ${ }^{288}$ Yet not only does the Neuer Markt have stricter disclosure and listing standards than its own parent, the Deutsche Börse, but it actually prides itself on being the "most regulated market" in Europe. ${ }^{289}$ Such a strategy seems identical to that of the NYSE a century earlier: develop reputational capital by pledging to observe requirements far stricter than those required by local law. The Neuer Markt's success has already produced attempts to imitate it continents away. ${ }^{290}$ The point here is not that law does not matter, but that partial functional substitutes for formal legal requirements are both feasible and spreading.

286. In Professor Black's study, a one-standard deviation change in governance ranking predicted an eight-fold increase in firm value. $I d$. at 2133 .

287. A recent study of 495 companies by CLSA Emerging Markets has reached similar conclusions to Professor Black's study. This study found that while the stocks of the 100 largest companies in the sample fell by $8.7 \%$ in 2000 , the stocks of the 25 companies rated best for corporate governance rose by an average of $3.3 \%$. It concluded that the correlation between good corporate governance and share performance for large companies is "a near perfect fit." Phillip Day, Corporate Governance Can Be Strong Indicator of Stock Performance Within Emerging Markets, WALL ST. J., May 1, 2001, at Cl4.

288. Vanessa Fuhrmans, Playing by the Rules: How Neuer Markt Gets Respect, WALL ST. J., Aug. 21, 2000, at C1.

289. Id. (quoting Deutsche Börse Chief Executive Werner Seifert)

290. Brazil's Novo Mercado is the clearest example. It invited U.S. institutional investors to help it design its listing rules, which forbid the issuance of nonvoting shares and require compliance with U.S. or international accounting standards. Merrill Lynch ranks the new exchange as significantly more protective of minority investors than the main Brazilian exchange. See Craig Karmin \& Jonathan Karp, Brazilian Market Tries Friendly Approach, WaLL ST. J., May 10, 2001, at C1. Thus, as in the case of the Neuer Markt, the newest exchange must bond itself more. 


\section{CONCLUSION}

The ongoing debate over common-law versus civil-law legal systems may have obscured the greater impact of a hidden variable on the growth of securities markets, namely, the level of state involvement in economic decision-making. Three generalizations emerge from a historical examination of the rise of dispersed ownership.

First, the growth of securities exchanges and the rise of dispersed ownership correlate most closely not with specific legal rules or protections, but with the appearance of a private sector that is relatively free from direct governmental interference. A political economy that was decentralized and pluralistic fostered the growth of securities markets by permitting private entrepreneurs to devise their own techniques with which to make their promises credible. In more centralized economies, the government found it more convenient to use large banks to accomplish its purposes. Thus, securities markets first arose in Amsterdam and Londontwo societies characterized by relative decentralization, but having very different legal systems. This suggests that doctrinal legal differences had only a secondary impact and that the fundamental precondition for the separation of ownership and control was the recognition-both legal and political - of the presumptive autonomy of the private sector.

A case can be made that the greater activism and entrepreneurial energy shown by private institutions in the common-law world is at least partially attributable to the common law's greater tolerance for private law-making. But even in the common-law world, the emergence of self-regulation was not automatic. Organizational differences and other path dependent reasons explain why the NYSE moved more quickly than the LSE to protect shareholders and raise listing standards. In the absence of pervasive judicial corruption or regulatory arbitrage, there was less urgency in the United Kingdom than in the United States to develop bonding mechanisms or other protections for minority investors. Add to this the fact that the United States was a capital-importing debtor nation, while the United Kingdom was a capital-exporting creditor, ${ }^{291}$ and the quicker pace of developments at the NYSE becomes easily understandable.

Perhaps the more striking contrast during the late nineteenth and early twentieth centuries was that between private exchanges (such as the LSE and the NYSE) and the virtual state-run monopoly that was the Paris Bourse. The active role taken by the French government in intruding so deeply into the affairs of the Paris Bourse that the Ministry of Finance had

291. Between 1870 and 1900 , foreign investment in the United States more than doubled. See CAROsso, supra note 71 , at 30 . Correspondingly, capital was flowing from the United Kingdom to overseas borrowers, as from 1856 to 1913 net overseas assets in the United Kingdom rose from $9.3 \%$ of all assets to $34 \%$. See MiCHIE, supra note 70, at 112 . 
to approve all new listings and transfers of seats seems a paradigm of the kind of state control that could suffocate the development of both selfregulation and innovation. Yet, virtually this same level of statist involvement in listing decisions seems evident today in contemporary China. ${ }^{292}$ Such state intrusion in the market seems likely to outweigh the impact of legal variables, including the choice between common-law and civil-law rules.

Second, to the extent that any political theory can explain the persistence of concentrated ownership, that theory is that it has protected entrenched incumbents from competition and innovation. It was not coincidental that both the NYSE and LSE faced (and ultimately overcame) active competitors in the late nineteenth century, while the competitors of the Paris Bourse were legislatively constrained. Although it cannot be proven that the more decentralized character of common-law legal institutions made inevitable the rise of self-regulatory bodies in the United States and the United Kingdom, it is considerably clearer that private monopolies (such as the Paris Bourse) were the product of a centralized state-run economy. To this extent, the French experience suggests a basic reason for the slower growth and evolution of securities markets in civillaw countries: that competition and innovation go hand-in-hand.

More generally, bank-centered economies appear to facilitate government control over the flow of investment, while market-centered economies impede such control. ${ }^{293}$ Although real historical examples fit this simpler political theory of concentrated ownership, in contrast, no concrete evidence shows that concentrated ownership has served as a protection for shareholders against the redistributive designs of social-democratic governments. Rather, much contemporary evidence demonstrates that concentrated ownership systems can serve as a means by which powerful families and governments reinforce each other and control economies in some areas of the Third World. Crony capitalism is the dark side of concentrated ownership, and it has simply been ignored by the proponents of political theories of finance.

292. Although China has an active and volatile securities market, "China's government controls the vast majority of the companies whose shares trade on the country's two exchanges, in Shanghai and Shenzhen, and so far, politics has played a larger role than profits in the companies' fates." Craig S. Smith, Shanghai Exchange Expels a Poorly Performing Stock, N.Y. TIMES, Apr. 25,2001 , at $W 1$. Until this year, exchange officials had not enforced listing requirements with respect to "state-owned, politically well-connected enterprises." Id. When one such company was delisted by the Shanghai Exchange after four consecutive years of losses, this precedent merited a story in the New York Times, but even that story concluded that stock exchange "enforcement is likely to remain highly politicized, with little clear sign of why some companies are delisted and others not." Id. The French model of politicized exchange regulation may then have a modern analogue.

293. See supra notes 281-282 and accompanying text. 
The rise of dispersed ownership has recently encountered little political opposition, but this may be because the barriers to free trade and crossborder capital flows have already fallen. ${ }^{294}$ Some hostility to the growth of securities markets can be dimly discerned in Europe, but it dates back to the late nineteenth century and was most evident at that time in Germany, ${ }^{295}$ a country that could not then be called by any stretch of the imagination a social democracy. Correspondingly, the reliance of German firms on bank finance seems to have been state-determined, in large part caused by legislative restrictions on the issuance of securities. ${ }^{296}$ The limited amount of legislation that has restricted securities markets in Europe seems to have been less the product of rent-seeking by banks than the moralistic sense of legislators, prodded by scandals, that trading on the stock market was "little better than gambling." 297 No plausible connection is historically discernable, however, between the rise of the social welfare state and the decline of securities markets. Although European securities markets declined in relative size during most of the twentieth century, two world wars that devastated the continent of Europe supply the most sensible explanation for that decline.

Third, the cause and effect sequence posited by the LLS\&V thesis may in effect read history backwards. They argue that strong markets require strong mandatory rules as a precondition. Although there is little evidence that strong legal rules encouraged the development of either the New York or London Stock Exchanges (and there is at least some evidence that strong legal rules hindered the growth of the Paris Bourse), the reverse does seem to be true: Strong markets do create a demand for stronger legal rules. Both in the United States and the United Kingdom, as liquid securities markets developed and dispersed ownership became prevalent, a new political constituency developed that desired legal rules capable of filling in the inevitable enforcement gaps that self-regulation left. Both the federal securities laws passed in the 1930s in the United States and the Company Act amendments adopted in the late 1940s in the United Kingdom were a response to this demand (and both were passed by essentially socialdemocratic administrations seeking to protect public securities markets). More recently, as markets have matured across Europe, similar forces have

294. This is essentially the hypothesis that Rajan and Zingales have offered. See supra notes 61-63 and accompanying text.

295. See MiCHIE, supra note 113, at 42 (finding that "German companies were denied the ease of access to finance via security issues that their British counterparts enjoyed").

296. See infra notes 213-222 and accompanying text.

297. For this assessment of public attitudes toward stock trading at the end of the nineteenth century in both the United Kingdom and Europe (and particularly Germany), sec Michie, supra note 104, at 286. This interpretation is, of course, consistent with Professor Banner's thesis that securities legislation is adopted only in the wake of scandals. See Banner, supra note 13. 
led to the creation of European parallels to the SEC. ${ }^{298}$ In each case, law appears to be responding to changes in the market, not consciously leading it.

In this light, if private institutional structures played the pivotal role in the rise of dispersed ownership in the United States and the United Kingdom, what does this fact portend for the future of corporate governance in Europe and in transitional economies? The good news in this Article is that self-regulation might take hold in Europe and in the transitional economies, even though optimal legislation remains lacking. The bad news is that the mere transplanting of U.S. or U.K. law to transitional economies may not accomplish its intended goals if the government still directs, approves, and vetoes major economic decisions in the private sector. Currently, the state's hand in purely economic decisions such as exchange listings remains easily visible in many countries. ${ }^{299}$ Once concentrated ownership degenerates into a "crony capitalism" that unites political and economic power, the role of law is likely to become minimal.

To the extent that a decentralized political economy was the critical precondition that enabled active securities markets to arise in both Holland and England, the appearance of open, competitive markets in transitional economies will be the more telling signal that a real transition has occurred and that capital markets can develop. Even in a legal environment in which investor protection is substandard, the optimist can still hope that private actors may develop private institutions capable of partially filling this legal vacuum, just as they did in the United States during the late nineteenth century. Rather than wait for optimal legislation to be enacted, companies in these countries have the practical ability to adopt governance and contractual reforms that will enable them to access Western financial markets or to distinguish themselves credibly from firms in their own markets that remain ready to exploit minority investors. By no means does this imply that stronger legislation protecting minority rights is not desirable, but historically this step has followed, rather than preceded, the initial growth of the equity market.

Today, the most dynamic forces on the European stage are not the various efforts to secure harmonized corporate and securities law, but rather the quieter changes that are currently underway in the markets themselves, including (1) the inexorable movement toward a pan-European stock exchange; (2) the increased activity of securities analysts with regard to European corporations with minority public ownership; ${ }^{300}$ (3) the

298. See supra note 258 and accompanying text.

299. See supra note 292 and accompanying text.

300. On this important theme, see James J. Chang ET AL., ANALYST ACTIVITY AROUND THE WORLD, (SSRN Elec. Library, Working Paper No. 204,570, 2000) (finding analysts able to 
accelerating convergence in international accounting standards; ${ }^{301}$ and (4) the current international wave of mergers and acquisitions. None of these conclusions denies that remedial legislation is desirable in order to establish stronger minority protections, but the United States's and the United Kingdom's experiences suggest that if private actors can generate credible signals that investor rights will be protected, then an equity market can arise, and in time protective legislation will predictably follow. Indeed, selfregulatory initiatives have already begun to play a critical role in the development of European securities markets, particularly in countries where the prevailing legal rules seem weak. ${ }^{302}$

For the future, the most likely scenario is that once these forces have created a stronger constituency for open and transparent markets, that constituency will demand and obtain the necessary legislative reforms to fill in the inevitable gaps. Although optimistic, such a scenario is consistent with what actually happened during the late nineteenth century in America and Britain, and also with what might have occurred in Germany, but for a legislative overreaction. This usable past furnishes an immediate lesson for the future - the past could again become prologue.

penetrate and restate earnings of companies with concentrated ownership and nontransparent accounting), available at http://papers.ssm.com/paper.taf?abstract_id=204570.

301. See Judy Land \& MARK LANG, EMPIRICAL EVIDENCE ON THE EVOlution OF GlOBal ACCOUNTING (SSRN Elec. Library, Working Paper No. 233,602, 2000) (finding strong evidence of such convergence), available at http://papers.ssm.com/paper.taf?abstract_id=233602.

302. See supra notes 284-289 and accompanying text. 